\title{
VARIABILIDADE E BASE GENÉTICA DA PUNGÊNCIA E DE CARACTERES DO FRUTO: IMPLICAÇÕES NO MELHORAMENTO DE UMA POPULAÇÃO DE Capsicum annuum L.
}

\author{
CAROLINE MOOR WAGNER
}

Tese apresentada à Escola Superior de Agricultura "Luiz de Queiroz", Universidade de São Paulo, para obtenção do título de Doutor em Agronomia, Área de Concentração: Genética e Melhoramento de Plantas.

P I R A C I C A B A

Estado de São Paulo - Brasil

Fevereiro - 2003 


\title{
VARIABILIDADE E BASE GENÉTICA DA PUNGÊNCIA E DE CARACTERES DO FRUTO: IMPLICAÇÕES NO MELHORAMENTO DE UMA POPULAÇÃO DE Capsicum annuum L.
}

\section{CAROLINE MOOR WAGNER}

Engenheiro Agrônomo

\author{
Orientador: Prof. Dr. ROLAND VENCOVSKY
}

Tese apresentada à Escola Superior de Agricultura "Luiz de Queiroz", Universidade de São Paulo, para obtenção do título de Doutor em Agronomia, Área de Concentração: Genética e Melhoramento de Plantas.

P I R A C I C A B A

Estado de São Paulo - Brasil

Fevereiro - 2003 
Dados Internacionais de Catalogação na Publicação (CIP) DIVISÃO DE BIBLIOTECA E DOCUMENTAÇÃO - ESALQ/USP

\footnotetext{
Wagner, Caroline Moor

Variabilidade e base genética da pungência e de caracteres do fruto : implicações no melhoramento de uma população de Capsicum / Caroline Moor Wagner. - - Piracicaba, 2003.

$104 \mathrm{p}$.

Tese (doutorado) - Escola Superior de Agricultura Luiz de Queiroz, 2003. Bibliografia.

1. Ardência 2. Fisiologia vegetal 3. Genótipos 4. Melhoramento genético vegetal 5. Pimenta 6. Pimentão 7. Populações vegetais 8. Seleção (Genética) 9. Variação genética em plantas I. Título
}

CDD 635.643

\section{"Permitida a cópia total ou parcial deste documento, desde que citada a fonte - $\mathrm{O}$ autor"}


Dedico:

Aos funcionários de campo e técnicos agrícolas que trabalham anonimamente para que todo o trabalho de melhoramento genético e pesquisa sejam realizados. Sem eles nada disso seria possível;

Ao prof. Fernando Luís Caprio da Costa que escolheu para mim os melhores orientadores que uma pessoa poderia ter nas áreas de melhoramento genético vegetal e genética quantitativa: $\mathcal{A}$ profa. Sandra Christina Koeth Milach e o prof. Roland Vencovsky;

À Cláudia Ríbe iro, Daíse Lopes, Gláucia Buso, Francisco Re ifschneider e Roland Vencovsky pelo exemplo de dedicação à pesquisa e pelo respeito e consideração com que sempre me trataram. 


\section{AGRADECIMENTOS}

Ao concluir minha graduação, lembro ter tido o primeiro contato com um certo livro de capa verde, que tratava de genética biometria no fitomelhoramento. Na ocasião, recordo que além do título, não entendia muito do conteúdo. Mas já naquela época sabia que o conteúdo daquele livro seria importante na minha formação profissional como melhorista. Desde então passei a nutrir uma grande admiração pelo primeiro autor daquele livro, e a cada história que escutava sobre tão ilustre professor, mais minha admiração e respeito iam crescendo. Foi com enorme satisfação que tive a oportunidade de tê-lo como meu orientador nestes anos de doutorado. Ao professor Roland Vencovsky pelo exemplo de vida, pesquisa e orientação e pela confiança em mim depositada. Com certeza a oportunidade de ter convivido com o senhor contribuiu de forma decisiva não só na minha formação profissional, como também na pessoal.

Aos pesquisadores Cláudia Silva da Costa Ribeiro; Gláucia Buso; Daise Lopes e Francisco Reifschneider por terem me orientado mesmo na ausência de um vínculo oficial e pela amizade, consideração e respeito com que sempre me trataram. Certamente aprendi um pouco com cada um de vocês.

À Embrapa Hortaliças, Embrapa Agroindústria de Alimentos, Embrapa Recursos Genéticos e Biotecnologia e Núcleo de Pesquisa de Produtos Naturais NPPN/UFRJ, por terem aberto as portas de suas instituições para a realização deste trabalho.

Aos pesquisadores Sabrina Carvalho e Luciano Bianchetti pela ajuda no trabalho, pelo incentivo e amizade. Aos pesquisadores Humberto Biso e Rosemar Antoniassi e ao professor Antônio Jorge pelo auxílio e apoio recebidos. 
À David Régis de Oliveira pelo exemplo de dedicação a pesquisa, pelos finais de semana e noites que trabalhou para que este estudo fosse realizado. À Patricía, Bernardo, Andréia, Wodson e Mário pelo auxílio na secagem e moagem das pimentas.

Aos técnicos Athayde, Válter e Valdecir, aos funcionários Deosimar, Rivelino, Jacinto, Antônio (Tonhão) e Zé batata e ao estagiário Francisco Jr. pela dedicação e empenho com que sempre tiveram neste trabalho e pelos finais de semana que deixaram de estar com suas famílias para auxiliar na condução do experimento.

Ao pesquisador Antônio Williams Moita pela ajuda nas análise estatísticas e pela consideração e amizade.

Aos colegas de curso pelo exemplo de companheirismo e apoio recebidos.

Aos amigos: Maria Imaculada Zucchi, Baldin, Andréa Mittelman, Alessandra Fávero, Eduardo Leonardecz, Glauce Rumin, Maria Tereza, Ricardo e Patrícia Felipe Cardoso, pela amizade, apoio e hospedagem. Conhecer vocês foi uma das coisas boas que aconteceram neste doutorado. Aos amigos Luciana Cursino dos Santos, Mateus Mondin e Andréa Mittelman e minha mãe, pelas pelas sugestões e ajuda na correção da redação deste trabalho.

Às amigas Caroline Castro e Kátia Marzall pelo ombro amigo nas horas difíceis e por festejarem comigo nos momentos de alegria.

Aos professores e funcionários do departamento de genética, em especial a Silvana, Fernando, Berdan e Macedônio.

À meus tios Elmar Wagner e Elizabeth Moor Wagner e meu primo Christian Robert Moor Wagner pelo apoio, incentivo e por terem me recebido em sua casa.

Ao meu irmão Derek George Moor Wagner e minha cunhada Sara Volpato, pelo apoio, incentivo, hospedagem e serviço de transporte. À minha mãe Anne Marie Moor McCulloch, minha avó Dorothy Watson McCulloch de Moor, meu avô Gilbert Richard Juan Luiz Moor Balparda (in memoria) e meus irmãos Richard Moor Wagner e Jennifer Moor Wagner pelo apoio, incentivo, suportes financeiro e emocional e por estarem sempre presentes. 
À todos aqueles que se esforçaram ao máximo para que estes anos de doutoramento fossem o mais estressantes possíveis. Sem vocês eu não teria me tornado uma pessoa mais tolerante.

Ao CNPq pela concessão da bolsa de estudo. 


\section{SUMÁRIO}

Página

LISTA DE FIGURAS............................................................................

LISTA DE TABELAS ..............................................................................

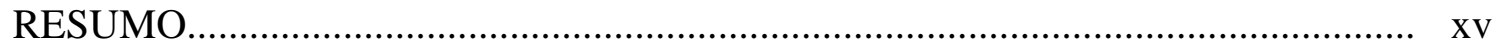

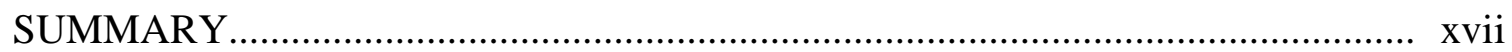

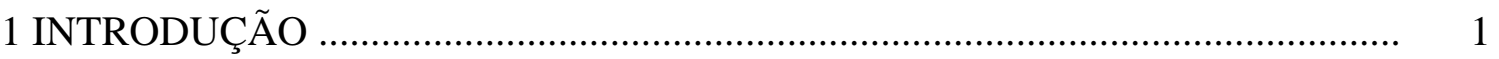

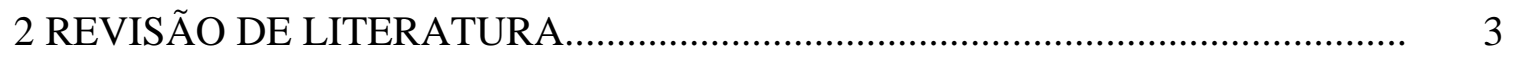

2.1 Bioquímica da pungência............................................................................. 5

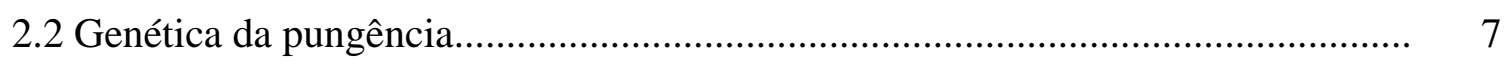

2.3 Interação genótipo x ambiente na pungência....................................................... 11

2.4 Produtividade, espessura da polpa, tamanho do fruto e descritores morfológicos.................................................................................... 13

2.5 Métodos de análise da pungência............................................................... 15

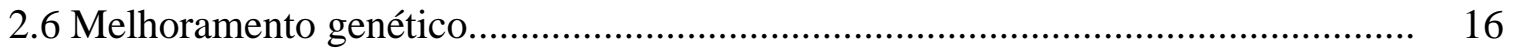

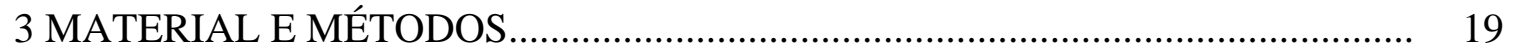

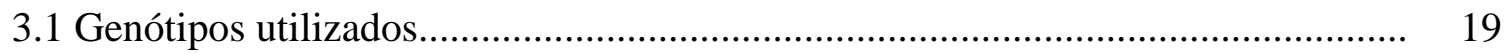

3.2 Condução do experimento.............................................................................. 20

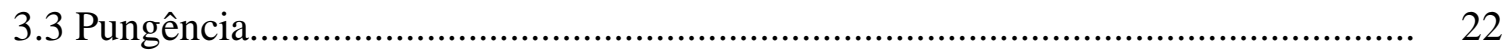

3.3.1 Histogramas de distribuição de freqüência dos dados da pungência................... 23

3.3.2 Análise de variância da pungência .................................................................. 23

3.3.3 Componentes de média da pungência........................................................... 28

3.3.4 Análise de correlação................................................................................. 29

3.4 Produtividade e demais caracteres do fruto.................................................... 30

3.4.1 Histogramas de distribuição de freqüência dos dados de produtividade e 
demais caracteres do fruto.................................................................. 31

3.4.2 Análises estatísticas dos dados de produtividade e demais caracteres do fruto...

3.4.3 Componentes de média de produtividade e demais caracteres do fruto.

3.4.4 Resposta correlacionada à seleção para pungência sobre a produtividade e demais caracteres do fruto.......................................................................... 31

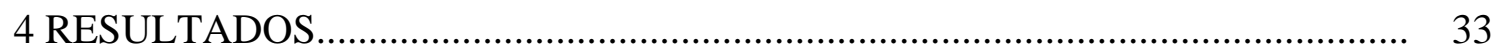

4.1 Análises cromatográficas.............................................................................. 33

4.2 Histogramas dos dados de pungência................................................................ 33

4.3 Análise de variância da pungência...................................................................... 39

4.4 Componentes de média da pungência............................................................... 39

4.5 Análise de correlação..................................................................................... 46

4.6 Histogramas de distribuição de freqüência dos dados de produtividade e demais caracteres do fruto......................................................................................... 48

4.7 Análises estatísticas da produtividade e demais caracteres do

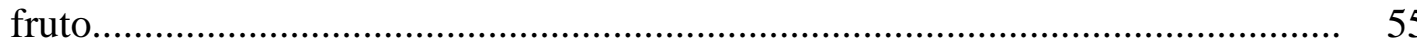

4.8 Componentes de média da produtividade e demais caracteres do fruto................ 56

4.9 Resposta correlacionada à seleção para pungência sobre a produtividade e demais caracteres do fruto............................................................................... 59

5 DISCUSSÃO

5.1 Análises cromatográficas................................................................................. 64

5.2 Histograma dos dados de pungência..................................................................... 64

5.3 Análise de variância da pungência..................................................................... 65

5.4 Componentes de média da pungência.................................................................. 67

5.5 Ganho genético com seleção da pungência............................................................. 70

5.6 Análise de correlação.................................................................................. 72

5.7 Histogramas de distribuição de freqüência dos dados de produtividade e demais caracteres do fruto....................................................................................... 73

5.8 Análise de variância da produtividade e demais caracteres do fruto....................... 73 
5.9 Componentes de média da produtividade e demais caracteres do fruto................ 74

5.10 Resposta correlacionada à seleção para pungência sobre a produtividade e demais caracteres do fruto................................................................... 74

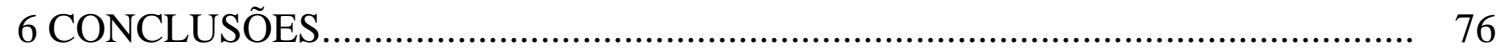

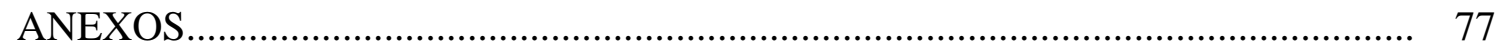

REFERÊNCIAS BIBLIOGRÁFICAS....................................................... 97 


\section{LISTA DE FIGURAS}

Página

1 Cromatograma da nordiidrocapsaicina, capsaicina, pico não identificado e diidrocapsaicina com o tempo de retenção em minutos no eixo do $\mathrm{X}$ e a miliabsorbância (mAbs) no eixo Y; e os perfis dos espectros (nanômetro no eixo X e mAbs no Y) Capsicum annuum L. 2002.

2 A) Cromatograma com os picos da nordiidrocapsaicina, capsaicina e diidrocapsaicina, respectivamente; B) cromatograma com o pico não identificado; C) cromatograma de um genótipo doce. Capsicum annuum L. 2002

3 Histogramas de distribuição de freqüência das análises nordiidrocapsaicina, em unidade scoville de calor ( $\mathrm{SHU}$ ) para as gerações $\mathrm{P}_{1}, \mathrm{P}_{2}, \mathrm{~F}_{1}, \mathrm{RC}_{11}$ e $\mathrm{F}_{4}$, com as médias das gerações plotadas na base do gráfico da geração $\mathrm{F}_{4}$. Capsicum annuum L. 2002.

4 Histogramas de distribuição de freqüência das análises capsaicina, em unidade scoville de calor ( $\mathrm{SHU}$ ) para as gerações $\mathrm{P}_{1}, \mathrm{P}_{2}, \mathrm{~F}_{1}, \mathrm{RC}_{11}$ e $\mathrm{F}_{4}$, com as médias das gerações plotadas na base do gráfico da geração $\mathrm{F}_{4}$. Capsicum annuum $\mathrm{L}$. 2002

5 Histogramas de distribuição de freqüência das análises de diidrocapsaicina em unidade scoville de calor ( $\mathrm{SHU}$ ) para as gerações $\mathrm{P}_{1}, \mathrm{P}_{2}, \mathrm{~F}_{1}, \mathrm{RC}_{11}$ e $\mathrm{F}_{4}$, com as médias das gerações plotadas na base do gráfico da geração $\mathrm{F}_{4}$. Capsicum annuum L. 2002

6 Histogramas de distribuição de frequiência das análises de capsaicinóides totais, em unidade scoville de calor ( $\mathrm{SHU}$ ) para as gerações $\mathrm{P}_{1}, \mathrm{P}_{2}, \mathrm{~F}_{1}, \mathrm{RC}_{11}$ e $\mathrm{F}_{4}$, com as 
médias das gerações plotadas na base do gráfico da geração $\mathrm{F}_{4}$. Capsicum

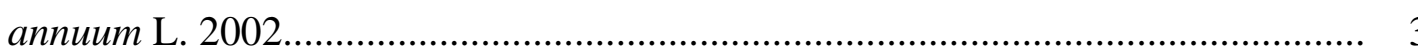

7 Histogramas de distribuição de freqüência dos dados de largura do fruto em $\mathrm{cm}$ das gerações $\mathrm{P}_{1}, \mathrm{P}_{2}, \mathrm{~F}_{1}, \mathrm{RC}_{11}$ e $\mathrm{F}_{4}$, com as médias das gerações plotadas na base do gráfico da geração $\mathrm{F}_{4}$. Capsicum annuum L. 2002 ............................................

8 Histogramas de distribuição de freqüência dos dados de comprimento do fruto em $\mathrm{cm}$ das gerações $\mathrm{P}_{1}, \mathrm{P}_{2}, \mathrm{~F}_{1}, \mathrm{RC}_{11}$ e $\mathrm{F}_{4}$, com as médias das gerações plotadas na base do gráfico da geração $\mathrm{F}_{4}$ Capsicum annuum L. 2002 ..................................... 50

9 Histogramas de distribuição de freqüência dos dados de espessura da polpa em mm das gerações $\mathrm{P}_{1}, \mathrm{P}_{2}, \mathrm{~F}_{1}, \mathrm{RC}_{11}$ e $\mathrm{F}_{4}$, com as médias das gerações plotadas na base do gráfico da geração $\mathrm{F}_{4}$ Capsicum annuum L. 2002 .....................................

10 Histogramas de distribuição de frequiência dos dados de produtividade em $\mathrm{g}$ das gerações $\mathrm{P}_{1}, \mathrm{P}_{2}, \mathrm{~F}_{1}, \mathrm{RC}_{11}$ e $\mathrm{F}_{4}$, com as médias das gerações plotadas na base do gráfico da geração $\mathrm{F}_{4}$. Capsicum annuum L. 2002.

11 Histogramas de distribuição de frequiência dos dados de número de fruto das gerações $\mathrm{P}_{1}, \mathrm{P}_{2}, \mathrm{~F}_{1}, \mathrm{RC}_{11}$ e $\mathrm{F}_{4}$, com as médias das gerações plotadas na base do gráfico da geração $\mathrm{F}_{4}$. Capsicum annuum L. 2002 ......

12 Histogramas de distribuição de freqüência dos dados peso médio do fruto em $\mathrm{g}$ das gerações $\mathrm{P}_{1}, \mathrm{P}_{2}, \mathrm{~F}_{1}, \mathrm{RC}_{11}$ e $\mathrm{F}_{4}$, com as médias das gerações plotadas na base do gráfico da geração $\mathrm{F}_{4}$. Capsicum annuum L. 2002. 


\section{LISTA DE TABELAS}

Página

1 Número de parcelas por geração em cada bloco, utilizados para avaliação da pungência em frutos de pimenta.................................................................. 20

2 Número de parcelas e número de plantas amostradas por gerações nos três blocos, utilizados para avaliação da produtividade, número de frutos, peso médio do fruto, largura e comprimento do fruto e espessura da polpa em frutos de pimenta..

3 Esquema da análise de variância de médias de parcela, com fontes de variação (FV), graus de liberdade (GL), quadrados médios (QM) e esperanças dos quadrados médios $[\mathrm{E}(\mathrm{QM})]$. Dados de pungência.

4 Análise de variância de médias de parcela, com fontes de variação (FV), graus de liberdade (GL), quadrados médios (QM), teste F, média geral, coeficiente de variação (C.V.), estimativas das variâncias genética e residual e herabilidade no sentido amplo, de nordiidrocapsaicina (Nordiidro), capsaicina, diidrocapsaicina (Diidro) e capsaicinóides totais (Caps. Totais). Capsicum annuum L. 2002

5 Médias observadas e esperadas de nordiidrocapsaicina (nordiidro), capsaicina, diidrocapsaicina (diidro) e capsaicinóides totais (Caps. Totais), nas cinco gerações, obtidos da análise de componentes de médias para quatro parâmetros com os respectivos valores do teste de qui-quadrado. Capsicum annuиm L. 2002 .

6 Capsaicinóides. Hipóteses de segregação genética, freqüências observadas e esperadas de progênies doces e pungentes e teste do qui-quadrado. Capsicum annuum L. 2002.

7 Número de observações (n) e médias das progênies $\mathrm{F}_{4.3}$ nos três blocos para 
nordiidrocapsaicina (nordiidro), capsaicina, diidrocapsaicina (diidro) e capsaicinóides totais (Caps. Totais). Capsicum annuum L. 2002............................

8 Médias das progênies selecionadas $\left(\overline{\mathrm{Y}}_{\mathrm{s}}\right)$, da população original $\left(\overline{\mathrm{Y}}_{\mathrm{o}}\right)$ e ganho com seleção (Gs) para aumentar e diminuir a pungência, sob diferentes pressões de seleção $(5 \%, 10 \%$ e 20\%) para nordiidrocapsaicina, capsaicina, diidrocapsaicina e capsaicinóides totais. Capsicum annuum L. 2002.....................

9 Resultado da análise de correlação simples de Pearson entre as avaliações sensoriais do fruto e do extrato etanólico com capsaicinóides totais, quantificados

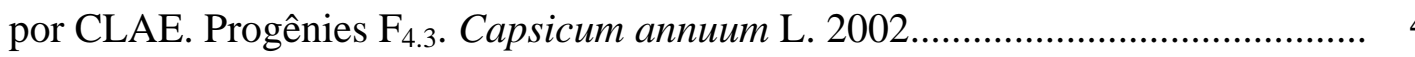

10 Análise de variância de médias de parcela, com fontes de variação (FV), graus de liberdade (GL), quadrados médios (QM), teste $\mathrm{F}$, coeficiente de variação (C.V.), estimativas das variâncias genética e residual e herdabilidade no sentido amplo, de largura e comprimento do fruto e espessura da polpa. Capsicum annuum L. 2002

11 Análise de variância de médias de parcela, com fontes de variação (FV), graus de liberdade (GL), quadrados médios (QM), teste F, média geral, coeficiente de variação (C.V.), estimativas das variâncias genética e residual e herdabilidade no sentido amplo, de produtividade, número de frutos e peso médio dos frutos. Capsicum annuum L. 2002 ......

12 Médias observadas e esperadas da largura e comprimento do fruto e espessura da polpa nas cinco gerações, obtidas da análise de componentes de médias com parâmetros e respectivos valores de Qui-quadrado. Capsicum annuum L. 2002.....

13 Médias observadas e esperadas da produtividade, número de frutos e peso médio do fruto nas cinco gerações, obtidas da análise de componentes de médias com parâmetros e respectivos valores de Qui-quadrado. Capsicum annuum L. 2002.....

14 Progresso direto (Gs) e resposta correlacionada (RCs) na largura e comprimento do fruto e espessura da polpa com seleção para aumento da pungência, sob diferentes pressões de seleção (\% sel.) em progênies $\mathrm{F}_{4.3}$ (Prog.). Capsicum annuиm L. 2002 
15 Progresso direto (Gs) e resposta correlacionada (RCs) na largura e comprimento do fruto e espessura da polpa com seleção para diminuição da pungência, sob diferentes pressões de seleção (\% sel.) em progênies $\mathrm{F}_{4.3}$ (Prog.). Capsicum

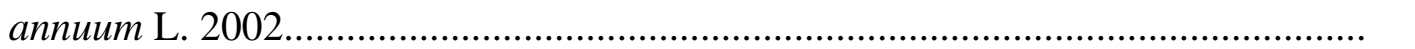

16 Progresso direto (Gs) e resposta correlacionada (RCs) na produtividade, número de frutos e peso médio do fruto com seleção para aumento da pungência, sob diferentes pressões de seleção (\% sel.) em progênies $\mathrm{F}_{4.3}$ (Prog.). Capsicum

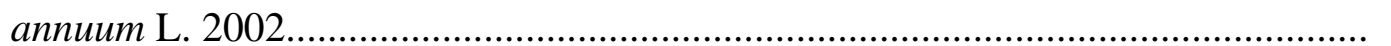

17 Progresso direto (Gs) e resposta correlacionada (RCs) na produtividade, número de frutos e peso médio do fruto com seleção para diminuição da pungência, sob diferentes pressões de seleção (\% sel.) em progênies $\mathrm{F}_{4.3}$ (Prog.). Capsicum

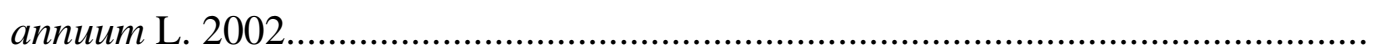




\title{
VARIABILIADADE E BASE GENÉTICA DA PUNGÊNCIA E DE CARACTERES DO FRUTO: IMPLICAÇÕES NO MELHORAMENTO DE UMA POPULAÇÃO DE Capsicum annuum L.
}

\author{
Autora: CAROLINE MOOR WAGNER \\ Orientador: Prof. Dr. ROLAND VENCOVSKY
}

\section{RESUMO}

Este trabalho está inserido no programa de melhoramento genético de Capsicum da Embrapa Hortaliças. Teve como principal objetivo investigar a base genética e a variabilidade de uma população segregante de Capsicum em relação à pungência e a alguns caracteres do fruto para, fornecer informações úteis ao programa. Os genótipos utilizados compreenderam dois genitores homozigóticos contrastantes para o caráter principal, a pungência, bem como as respectivas gerações $F_{1}, R_{11}$ e progênies $F_{4.3}$. Estas últimas num total de 100, foram obtidas pelo método SSD (single seed descent). Empregou-se delineamento em blocos casualizados com três repetições e dez plantas por parcela. As análises biométricas foram feitas com base em médias de parcelas. Os caracteres avaliados foram: pungência, produtividade, largura, comprimento, número e peso médio dos frutos e espessura da polpa. Investigou-se a segregação fenotípica das progênies $F_{4.3}$, classificando-as em pungentes e doces. Estimou-se o coeficiente de herdabilidade na base de médias de progênies em todos os caracteres. Simulando uma seleção entre progênies somente para a pungência, tanto para aumento como redução deste caráter, estimou-se o ganho esperado (Gs) sob intensidades de 20\%, 10\% e 5\%. Calculou-se a resposta correlacionada desta seleção sobre os demais caracteres. 
Paralelamente verificou-se a acuidade de avaliar a pungência utilizando métodos sensoriais, em comparação com o processo cromatográfico (CLAE). Estimaram-se os componentes genéticos das médias dos caracteres nas cinco gerações, considerando modelo aditivo-dominante e, quando necessário, incluindo componente epistático aditivo $\mathrm{x}$ aditivo. Verificou-se que, os genitores são contrastantes para todos os caracteres com exceção da espessura da polpa. $\mathrm{O}$ genitor doce deve conter genes para pungência não expressos. Os dados sugerem que, na população estudada, este caráter deve ser controlado por dois locos epistáticos, duplo-dominantes (9 pungentes : 7 doces em $F_{2}$ ) e genes modificadores. Os coeficientes de herdabilidade variaram de intermediários (66\%) a altos (92\%). Isso explicou os elevados ganhos esperados com a seleção para incrementar ou diminuir a pungência. Pelas respostas correlacionadas, verificou-se que, uma seleção para aumento da pungência deverá levar a uma redução na produtividade, sendo a recíproca também verdadeira. A avaliação da pungência por método cromatográfico foi de aproximadamente $30 \%$ mais eficiente do que o método sensorial. Pelos componentes de média observou-se a existência de heterose em todos os caracteres avaliados. O modelo incluindo efeitos epistáticos foi o mais adequado para explicar as médias das gerações, na maioria dos caracteres. Podem surgir indivíduos com frutos pungentes ao cruzar genitores doces. A segregação transgressiva em $\mathrm{F}_{4}$ é indicador de que tipos mais pungentes que o genitor pungente podem ser selecionados a partir desta população segregante. O melhoramento genético deste caráter pode ser estruturado tanto para explorar as variâncias genéticas aditiva e aditiva $\mathrm{x}$ aditiva em linhagens superiores como pode ser conduzido para capitalizar a heterose em híbridos de linhagens. Em programas iniciados cruzando-se linhagens, é fundamental identificar a constituição alélica dos genitores. É preciso monitorar a pressão seletiva numa seleção visando a pungência para evitar repostas correlacionadas indesejáveis. Para atingir máximos seletivos, para este caráter, é necessário levar em conta a existência de genes modificadores. 


\title{
VARIABILITY AND GENETIC BASIS OF PUNGENCY AND FRUIT CHARACTERS: IMPLICATIONS IN THE BREEDING OF A Capsicum annuum L. POPULATION
}

\author{
Author: CAROLINE MOOR WAGNER \\ Adviser: Prof. Dr. ROLAND VENCOVSKY
}

\section{SUMMARY}

This work is part of the Capsicum plant breeding program at Embrapa Hortaliças. The main objective was to investigate the genetic basis and variability of a segregating population of Capsicum, related to pungency and to some characteristics of the fruit, to provide information for the program. The genotypes that were used had two homozygotic parents, contrasting in their main characteristic, pungency, as well as the respective generations $F_{1}, R_{11}$ and progenies $F_{3.4}$. The latter, totaling 100 , were obtained using the SSD method (single seed descent). Randomized complete block design was used with three repetitions and ten plants per plots. The biometric analyses were based on a plot mean basis. The characters evaluated were pungency, productivity, width, length, number and average weight of the fruits and the thickness of the pulp. The fenotypical segregation of the $\mathrm{F}_{3.4}$ progenies were studied, being classified in pungent and sweet. The coefficient of heritability on a progeny mean basis were estimated in all the characters. Simulating a selection among progenies, only for pungency, for the increase as well as the reduction of this character, the expected gain (Gs) was estimated under intensities of $20 \%, 10 \%$ and $5 \%$. The correlated response of this selection was calculated over the remaining characters. Parallel to this, the acuity of evaluating the 
pungency, using sensorial methods, in comparison to the high pressure liquid chromatographic process (HPLC) was investigated. The genetic components of the trait means of the five generations, were estimated considering the additive dominant model, and, when necessary, including an additive $\mathrm{x}$ additive epistatic component. Results indicated that the parents are contrasting for all characters, with the exception of pulp thickness. The sweet parent should contain genes for pungency wich are not expressed. The data suggests that, in the population studied, this character is controlled by two doubly dominant epistatic loci, (9 pungent ones : 7 sweet ones in $\mathrm{F}_{2}$ ) and modifier genes. Coefficients of heritabilty varied from intermediate (66\%) to high (92\%). This explained the elevated expected gains from selection, to increase or decrease pungency. From the correlated responses, one could see that, selecting to increase pungency should lead to a reduction in productivity, being the reciprocal also true. The evaluation of pungency by a chromatographic method was approximately $30 \%$ more efficient than the sensorial method. By the genetic components of means, the existence of heterosis was observed in all the characters evaluated. The model which included epistatic effects was the most adequate to explain the average generation means in most of the characters. Individuals with pungent fruits can appear on crossing sweet parents. The transgressive segregation in $\mathrm{F}_{4}$ is an indicator that more pungent types than the pungent parent can be selected from this segregating population. Plant breeding of this character can be structured for the exploration of additive and additive $\mathrm{x}$ additive genetic variances in superior lines, or to capitalize the heterosis in hybrid of inbred lines. In programs initiated by crossing lines, it is fundamental to identify the allelic constitution of the parents. It is necessary to monitor the selective pressure in selection aiming at pungency, to avoid undesired correlated responses. To attain selective maximums, for this character, it is necessary to take into account the existence of modifier genes. 


\section{INTRODUÇÃO}

O Brasil é um importante centro de diversidade genética do gênero Capsicum e como tal, possui ampla variabilidade de pimentas e pimentões. Essa hortaliça está difundida em todas as regiões do Brasil, sendo que as principais áreas de cultivo estão localizadas nas regiões sudeste e centro-oeste. O seu cultivo é realizado por pequenos, médios e grandes produtores individuais ou integrados a agroindústrias.

As pimentas são uma cultura de grande importância sócio-economica. Contribuem como fonte geradora de renda na pequena propriedade e para fixação de pessoas na área rural. Aliado a isso é uma cultura geradora de empregos diretos e indiretos. As grandes agroindústrias do ramo das pimentas, possuem extensas áreas de cultivo (próprias e ou em parceria) empregando significativo número de pessoas, principalmente na época da colheita. O mercado é bastante diversificado, indo desde a comercialização de pimentas para consumo in natura e conservas caseiras até a exportação do produto industrializado.

Os frutos de Capsicum são consumidos na forma in natura ou processados como condimentos, conservas, corantes, na composição de remédios e indústria bélica (aerosol de pimenta). A principal características do fruto de pimenta é a pungência, conferida por substâncias alcalóides denominadas capsaicinóides. Existe mercado tanto para frutos com alta pungência (pimentas picantes e pomadas à base de capsaicina) como frutos sem pungência (pimentões e pimentas doces para consumo in natura e corantes). A diversidade genética de pimentas e pimentões está sendo utilizada em programas públicos e privados de melhoramento genético de Capsicum. Esses programas têm levado a ganhos significativos no aumento da pungência. Existe grande dificuldade em diminuir e eliminar a pungência dos frutos de plantas oriundas de populações segregantes, obtidas do cruzamento de plantas pungentes com doces. Outra dificuldade 
enfrentada pelos melhoristas é a grande influência ambiental, aliada a pouca informação genética disponível sobre esse caráter, o que dificulta o processo de seleção e a obtenção de genótipos estáveis.

Além da pungência outros caracteres também são importantes na seleção de pimentas e podem variar dependendo do mercado a que se destinam. Dentre esses é possível destacar a produtividade, o número de frutos por planta, o peso médio dos frutos, a largura e o comprimento do fruto e a espessura da polpa. No entanto, é importante ressaltar que no caso de programas de melhoramento que visam selecionar quanto à pungência, as respostas à seleção nos demais caracteres devem estar correlacionados ao caráter principal, no caso a pungência.

Pesquisadores da Embrapa têm feito um esforço coletivo no sentido de coletar e caracterizar parte da variabilidade genética de Capsicum no Brasil. Cabe ressaltar que este País é um importante centro de diversidade genética de Capsicum, mas apesar disso poucos estudos têm sido realizados nesta área. Todos os acessos coletados podem servir de fonte de genes de interesse para o melhoramento genético; no entanto é fundamental conhecer a base genética do caráter a ser melhorado. Assim, será possível traçar estratégias que permitam manipular o caráter de forma a minimizar a erosão genética e alcançar o objetivo desejado.

Nesse sentido, o presente trabalho objetivou estudar a variação genética da determinação da pungência em frutos de Capsicum, para que essa característica fosse melhor compreendida, e trabalhada de forma a maximizar o ganho genético com seleção para diferentes níveis de pungência nos programas de melhoramento genético de pimenta e pimentão. Outro objetivo deste trabalho foi estimar a resposta correlacionada esperada na produtividade, número e peso médio de frutos por planta, largura e comprimento dos frutos e espessura da polpa realizando-se seleção para pungência. 


\section{REVISÃO BIBLIOGRÁFICA}

O gênero Capsicum é representado pelas pimentas e pimentões. Do grego, kapso significa picar e kapsakes cápsula (Nuez, 1996). Esse gênero pertence à família Solanacea:

Divisão: Spermatophyta

Filo: Angiospermae

Classe: Dicotiledônea

Ramo: Malvales-Tubiflorae

Ordem: Solanales (Personatae)

Família: Solanaceae

Gênero: Capsicum

Existem aproximadamente 33 espécies de Capsicum divididas em espécies domesticadas, semi-domesticadas e silvestres. Capsicum annuum e C. chinense são espécies domesticadas que diferem entre si por uma translocação cromossômica e apresentam boa divergência genética (Reifschneider, 2000; Tanksley, 1984; Lanteri \& Pickersgill, 1993). O número cromossômico dessas espécies é 2n=2x=24.

Em 10 anos de estudos, utilizando 43 introduções de $C$. annuum e 11 de $C$. chinense, Smith \& Heiser (1957) concluíram que o cruzamento entre estas duas espécies pode ser feito nas duas direções, porém melhores resultados são obtidos quando se utiliza $C$. annuum como genitor feminino. Ocasionalmente foi obtido sucesso em cruzamentos na outra direção. $\mathrm{O}$ pólen das plantas $\mathrm{F}_{1}$ variou de completamente estéril a moderadamente fértil. Os resultados obtidos por Smith \& Heiser (1957) foram confirmados por Greenleaf (1986).

$\mathrm{Na}$ meiose de um cruzamento interespecífico $C$. annuum com $C$. chinense foi verificada, na diacinese, a presença de 48\% de 12 II; $8 \% 11$ II + 2 I ; $20 \% 10$ II + 1 IV; 
$16 \% 9$ II + 2 I + 1 IV; 4\% 10 II + 1 III + 1 I e 4\% 8 II + 2 IV (Tanksley, 1984), sendo: II pareamento cromossômico de bivalentes; I de univalentes; III de trivalentes e IV de tetravalentes. Este fato demonstra que, apesar da obtenção de plantas $F_{1}$ férteis, ocorre um desbalanço meiótico no cruzamento entre $C$. annuum e $C$. chinense. No mesmo trabalho Tanksley observou que a viabilidade do pólen dos genitores foi de $85 \%$ e $87 \%$ respectivamente, para os genitores $C$. annuum e $C$. chinense, enquanto na geração $\mathrm{F}_{1}$ foi de $12 \%$.

As espécies domesticadas do gênero Capsicum são, preferencialmente, autógamas com taxa de alogamia que pode variar de $3 \%$ a $46 \%$, dependendo da morfologia floral, da cultivar e da presença e número de insetos polinizadores (Saccardo, 1992).

O International Plant Genetic Resource Institute - IPGRI (1995) propôs uma listagem de descritores morfológicos e fenológicos que caracterizam o gênero Capsicum, dos quais alguns são importantes na diferenciação de espécies. Dentre os principais que diferenciam $C$. annuum de $C$. chinense estão a cor da flor, o número de flores por axila e a presença de constrição no cálice (Tanksley \& Iglesias-Oliva, 1984; Smith \& Heiser, 1957; Bianchetti 1996).

Uma das principais características do gênero Capsicum é a pungência, produzida por um conjunto de substâncias alcalóides, denominadas capsaicinóides. Esses ocorrem apenas no gênero Capsicum e são produzidos em glândulas presentes na placenta dos frutos. Dos aproximadamente 14 capsaicinóides existentes, os que ocorrem em maior quantidade são a capsaicina, a diidrocapsaicina e a nordiidrocapsaicina (Bosland, 1993).

A sensação de ardência provocada pelos capsaicinóides é percebida no organismo humano por receptores químicos que desencadeiam diversos processos fisiológicos. Um deles é a liberação de endorfinas, que provocam uma sensação de bem estar, provável razão pela qual existem tantos "adeptos" do consumo de Capsicum. Os capsaicinóides apresentam efeito diferenciado quanto à sensação de ardor. Dentre os três principais, a nordiidrocapsaicina é o capsaicinóide menos irritante, sendo sua ardência localizada na frente da boca e no palato. A sensação de ardor é percebida imediatamente 
após a ingestão da pimenta e rapidamente dissipada. Já, a capsaicina e diidrocapsaicina causam maior irritação e são descritas como tendo uma "típica" sensação de ardor no meio da boca e no palato, bem como na garganta e na parte posterior da língua (Krajewska \& Powers apud Bosland, 1993). Diferentes combinações de capsaicinóides produzem diferentes características de ardência em diferentes variedades de Capsicum (Collins \& Bosland, 1994). Estes pesquisadores comentam que, se o mercado de pimentas pungentes ficar mais sofisticado, os capsaicinóides provavelmente, deverão ser manipulados geneticamente para atender diferentes perfis de consumidores.

Estudos genéticos e bioquímicos estão sendo desenvolvidos para melhorar a compreensão desta característica, porém há controvérsias quanto aos resultados obtidos. Para o melhor entendimento da base genética da pungência é importante conhecer a bioquímica desta característica.

\subsection{Bioquímica da pungência}

Os capsaicinóides são substâncias alcalóides das quais, aproximadamente, 90\% encontram-se na placenta dos frutos (Ishikawa, et al., 1988). Já foram identificados 14 capsaicinóides (Kobata , 1998 apud Zewdie \& Bosland, 2000b), bem como novas substâncias químicas vêm sendo descobertas em espécies silvestres de Capsicum e identificadas como possíveis capsaicinóides (Lopes ${ }^{1}$ - informe pessoal).

A capsaicina é sintetizada pela condensação da vanililamina com uma cadeia de ácidos graxos de cadeia longa. Sendo os ácidos graxos sintetizados, a partir da valina e a valililamina proveniente da via dos fenilpropanóides (Leete e Louden 1968). Resultados semelhantes foram encontrados por Curry et al. (1999), que realizaram um estudo comparando os níveis de transcrição das enzimas fenilalanina amonia liase (PAL), ácido cinâmico 3-hydroxilase $(\mathrm{Ca} 4 \mathrm{H})$ e ácido cafeico $O$-metiltransferase (COMPT) em diferentes estádios de desenvolvimento dos frutos, além de tipos de tecido e níveis de pungência. Segundo estes pesquisadores os níveis de transcrição para os genes responsáveis pela expressão dessas três substâncias foram positivamente correlacionados com o nível de pungência no tecido da placenta de frutos de $C$. annuum e $C$. chinense.

1 Pesquisadora da Embrapa Agroindústria de Alimentos, 2002. 
Buscando identificar enzimas, cuja expressão fosse específica para tecidos da placenta, os mesmos pesquisadores estudaram o acúmulo de transcritos dos genes responsáveis pela informação de enzimas que atuam na via dos fenilpropanóides e dos ácidos graxos de cadeia longa. Foram identificados clones de aminotransferase responsáveis pela síntese de valililamina (pAmt) e de 3-keto-acil ACP sintetase (Kas), provável responsável pela elongação da cadeia de ácidos graxos de cadeia longa. Os genes responsáveis pela expressão dessas enzimas foram identificados como placentaespecíficos e apresentaram correlação positiva com a pungência dos frutos de pimenta.

Em estudo com cultura de células da placenta de C. frutescens, Johnson e Ravishankar (1998) demonstraram que a aplicação de intermediários da via dos fenilpropanóides e ácidos graxos de cadeia longa à cultura celular gerou um processo de bioconversão em capsaicina e diidrocapsaicina. Esses resultados foram confirmados num estudo in vitro e in vivo, no qual foi demonstrado que os metabólitos intermediários: vanililamina, L-fenilalanina, ácido cafeico, ácido cumárico, ácido felúrico e ácido cinâmico possuem boa capacidade de biotransformação em capsaicina e diidrocapsaicina. Foi demonstrado ainda que a vanililamina (doador do anel aromático à capsaicina) não é um intermediário limitante na produção de capsaicina (Johnson et al., 1992).

Uma rota alternativa para produção de vanilina (intermediário da via dos fenilpropanóides) foi proposta por Rao e Ravishankar (2000). Utilizando cultura de células de $C$. frutescens em suspensão esses pesquisadores demonstraram a biotransformação de aldeído protocatéquico e ácido cafeico em vanilina. O acúmulo máximo de vanilina e capsaicina, quando a suspenção celular foi tratada com aldeído protocatéquico, ocorreu no sexto e décimo quinto dias, respectivamente. Já quando tratadas com ácido cafeico o acúmulo máximo deu-se ao nonagésimo e décimo segundo dias, respectivamente.

A detecção de capsaicinóides nos frutos varia em função do genótipo e das condições ambientais. O início do acúmulo pode ser verificado de 14 a 40 dias após a 
antese, sendo o máximo de 25 a 70 dias e o decréscimo acima de cinqüenta dias após o florescimento (Estrada, et al., 2000; Kirschbaum-Titze, et al., 2002; Curry, et al., 1999).

Pesquisas comprovam que frutos de pimenta cultivados na primavera-verão são mais pungentes que os do outono-inverno. Isso ocorre porque o estresse influencia a via dos fenilpropanóides e afeta indiretamente a síntese de capsaicinóides (Kirschbaum-titze et al., 2002).

Quando células da placenta de frutos de pimenta sofrem ruptura celular sob condições de homogeneização, ocorre decréscimo no conteúdo de capsaicina. Esse decréscimo não é observado em frutos que são apenas cortados ao meio. $\mathrm{O}$ decréscimo no teor de capsaicinóides é menor quando os frutos são macerados em nitrogênio do que em oxigênio. Isso indica que processos oxidativos devem estar causando o decréscimo no teor de capsaicinóides (Kirschbaum-Titze, et al., 2002).

Em outra pesquisa foi verificado um decréscimo no conteúdo de peroxidase, lignina e substâncias fenólicas à exceção do ácido felúrico que só foi detectado na fase final de maturação (42 dias após a floração). Paralelamente ocorreu um acúmulo de capsaicinóides, indicando que estas alterações estão relacionadas ao metabolismo dos capsaicinóides. A peroxidase só pode oxidar a capsaicina após o decréscimo de lignina, que desestrutura a parede celular, fazendo com que a peroxidase e a capsaicina, que estavam em sub-compartimentos celulares distintos, possam interagir no mesmo compartimento celular (Estrada, et al., 2000; Bernal e Barceló, 1996). Bernal et al. (1993 e 1995) demonstraram como ocorre a oxidação da capsaicina e precursores fenólicos da capsaicina pela isoenzima básica peroxidase B6.

Confirmando esses resultados Contreras-Padilha \& Yahia (1997) verificaram uma relação inversa na evolução do teor de capsaicinóides e na atividade da peroxidase, indicando que esta enzima está envolvida na degradação dos capsaicinóides.

\subsection{Genética da pungência}

O controle genético da determinação dos níveis de pungência em frutos de Capsicum vem sendo estudado nos últimos 90 anos. Apesar de quase um século de 
pesquisas, o volume de trabalhos publicados é pequeno e dentre esses trabalhos existem controvérsias quanto aos resultados. Há uma tendência de os trabalhos mais antigos atribuírem a herança da pungência a um gene dominante, enquanto que os trabalhos realizados entre a década de 60 e os dias atuais, atribuem a herança dessa característica a poucos genes de efeito mais pronunciado e à existência de um complexo poligênico que regularia a expressão da pungência (Saccardo, 1992).

O primeiro estudo de genética da determinação da pungência foi realizado por Webber (1912 apud Greenleaf, 1986). Webber encontrou a proporção de 25 frutos pungentes para cinco frutos doces em plantas da geração $F_{2}$ do cruzamento de 'Red Chille' (pungente) x 'Golden Dawn' (doce), indicando a presença de um gene dominante controlando a determinação da pungência. Esses resultados foram confirmados por Deshpande (1935), que observou na $F_{2}$ a proporção de 202 frutos pungentes para 70 doces, em cruzamento de pimenta 'Cayene' com tipo 'Sweet Bell'. Estes dados foram ainda confirmados com a segregação da geração $F_{3}$, obtida da auto-fecundação de 10 plantas $F_{2}$ pungentes e cinco doces. Deshpande (1935) foi quem atribuiu o símbolo C para o gene da capsaicina e com base na segregação mendeliana observada atribuiu o genótipo cc às plantas de frutos doces e $\mathrm{C}_{-}$às plantas de frutos pungentes. $\mathrm{O}$ mesmo pesquisador comenta que nas gerações $\mathrm{F}_{2}$ e $\mathrm{F}_{3}$ as plantas foram classificadas em duas classes: pungentes e doces. Porém durante a análise sensorial, aquele autor relatou a dificuldade em realizar o painel (para análise sensorial) e a ocorrência de erros associados à análise, além de suspeitar da existência de diferentes níveis de pungência.

Pochard (1977) construiu um mapa genético de Capsicum, utilizando 11 trissômicos primários. Neste mapa localizou o gene C no cromossomo XI, também denominado trissômico Jaune.

Ohta (1960 e 1962 apud Greenleaf, 1986), utilizando métodos quantitativos (cromatografia) para determinação da pungência, identificou vários níveis de pungência na geração $F_{1}$ e distribuição bimodal na $F_{2}$ e retrocruzamento $(R C)$, evidenciando a presença de herança poligênica, sendo que um gene maior determinaria a pungência $\mathrm{e}$ um complexo poligênico regularia os níveis de expressão desta característica. Estudos de 
Yagishita (1990) confirmam em parte os resultados de Ohta. Para alguns cruzamentos foi aceita a hipótese de segregação na proporção de nove plantas pungentes para sete doces, indicando a presença de pelo menos dois genes de efeito epistático governando a determinação da pungência. Porém o autor comenta que é necessário maior número de plantas $\mathrm{F}_{2}$ e de cruzamentos distintos para verificar a precisão da informação genética.

Outro estudo que confirma a existência de herança genética quantitativa é o de Ribeiro \& Costa (1990). Foram encontrados valores altos de herdabilidade no sentido restrito para determinação da pungência em duas populações de pimenta (84\% e 78\%). As estimativas do grau médio de dominância indicaram a ocorrência de dominância parcial. A ocorrência de segregação transgressiva na geração $F_{2}$ e as estimativas dos componentes genéticos de variância indicaram que o conteúdo de capsaicina em $C$. chinense é controlado por vários genes de ação aditiva. Porém foram utilizadas apenas 20 plantas por geração em $\mathrm{P}_{1}, \mathrm{P}_{2}$ e $\mathrm{F}_{1}$, divididas em quatro repetições, e que comprometeu o erro experimental do estudo. Não ficou claro se os genitores utilizados estavam no estado de homozigose, um dos pré-requisitos para a utilização do método de estimativa dos componentes de médias através de quadrados mínimos desenvolvido por Mather \& Jinks (1982). O estudo de médias de gerações parte do pressuposto que, para a característica estudada, um genitor contém todos os alelos favoráveis e o outro, todos os desfavoráveis, o que nem sempre é verdade. Este método vem sendo utilizado com sucesso no estudo de inúmeros caracteres em espécies como, por exemplo, arroz, aveia, centeio, soja e trigo (Lagos , 1991; Pulcinelli, 1992; Ferreira et al., 1997; Gallego \& Benito, 1997; Sànchez-Chacòn, 1998).

Uma das vantagens deste método, é que as progênies utilizadas para estudar a segregação genética podem, também, serem utilizadas para análise de componentes de médias. Além disso, estimativas de médias tendem a ter distribuição normal, à medida que aumenta o tamanho amostral (Steel \& Torrie, 1960). As estimativas de componentes de variância, sendo melhores que as baseadas em médias para estudar a base genética de um caráter, são mais sujeitas a erros experimentais, se comparadas às estimativas de médias (Vencovsky \& Barriga, 1992; Ramalho et al., 1993). 
Um dos últimos trabalhos publicados sobre herança da pungência, merece especial atenção e exemplifica bem o que foi mencionado anteriormente. Em seu trabalho, Zewdie \& Bosland (2000a) estudaram a herança genética da determinação de cinco diferentes capsaicinóides e da pungência total. A herdabilidade, no sentido amplo, variou de $43 \%$, para capsaicina, até $85 \%$ para nordiidrocapsaicina e homodiidrocapsaicina, e $72 \%$ para pungência total. Foi utilizado pequeno número de plantas por geração, o que comprometeu a veracidade das estimativas de parâmetros genéticos. Esse fato foi observado através do pequeno número de graus de liberdade do erro experimental (10 g.l.) e do aparecimento de estimativas negativas de alguns componentes de variância.

As médias de pungência total das gerações $\mathrm{P}_{1}, \mathrm{P}_{2}, \mathrm{~F}_{1}, \mathrm{~F}_{2}, \mathrm{RC}_{11}$ e $\mathrm{RC}_{21}$ em $\left(\mathrm{mg}^{*} \mathrm{~kg}^{-1}\right)$ foram 13032, 24, 7116, 4554, 9336 e 1490, respectivamente; e para capsaicina 7819, 6, 2437, 1528, 4828 e 426 indicando a ocorrência de dominância parcial na determinação da pungência. Os efeitos epistáticos do tipo aditivo $\mathrm{x}$ aditivo, aditivo $\mathrm{x}$ dominante e dominante $\mathrm{x}$ dominante foram importantes na herança genética da capsaicina, diidrocapsaicina e do isomero de diidrocapsaicina. As estimativas obtidas pelos pesquisadores são questionáveis, pois os mesmos utilizaram apenas seis gerações para estimar seis parâmetros. Os autores concluíram que diferenças no efeito dos genes podem indicar que a síntese dos capsaicinóides é controlada por diferentes genes. A segregação nas gerações indicou uma herança quantitativa, o que explicaria a variação nos níveis de capsaicinóides.

As diferenças encontradas quanto à herança genética da determinação da pungência entre os diversos trabalhos publicados, provavelmente, deve-se ao fato de que nos primeiros trabalhos a quantificação da pungência foi realizada através de análise sensorial, enquanto nos trabalhos mais recentes foram utilizadas técnicas espectrofotométricas e cromatográficas, que são mais precisas. Esse fato ressalta a importância da necessidade de avaliações fenotípicas que representem de forma correta e precisa os níveis de pungência nas diferentes gerações. Outro ponto que chama atenção 
é o pequeno número de plantas utilizados por alguns grupos de pesquisa para a realização dos estudos genéticos.

Ao comparar os resultados genéticos quanto ao tipo de herança genética da determinação da pungência, com o número de enzimas que participam da via biosintética da capsaicina, seria lógico esperar a ocorrência de um complexo poligênico responsável pela expressão deste caráter.

O fenótipo de um dado caráter é função da genética, do ambiente e da interação genótipo $\mathrm{x}$ ambiente. No caso da pungência existe uma forte contribuição do fator ambiental sobre a sua expressão conforme abordado a seguir.

\subsection{Interação genótipo $x$ ambiente na pungência}

O conteúdo de capsaicinóides é afetado por condições ambientais, manejo da cultura e idade do fruto. Os melhoristas podem selecionar e desenvolver variedades com diferente nível de pungência. Do mesmo modo, fitotecnistas podem controlar a pungência de acordo com o manejo da cultura (Bosland, 1993).

Num estudo utilizando linhagens duplo-haplóides, Bosland \& Lindsey (1995) encontraram diferenças entre plantas dentro da mesma parcela da ordem de $1 \%$ a $70 \%$; e entre parcelas de $6 \%$ a $89 \%$ relativas ao conteúdo de capsaicinóides totais. Isto indica um forte efeito ambiental sobre a expressão da pungência, visto que a variação obtida entre plantas duplo-hapóides é de natureza ambiental.

Com o objetivo de pesquisar a resposta de genótipos de pimenta dentro e entre ambientes para o conteúdo de: capsaicina, diidrocapsaicina, nordiidrocapsaicina, homodiidrocapsaicina, um isômero de diidrocapsaicina e capsaicinóides totais, Zewdie

\& Bosland (2000) também utilizaram linhagens duplo-haplóides. O experimento foi realizado empregando delineamento experimental de blocos ao acaso em dois anos diferentes, utilizando sete blocos e quatro tratamentos. Cada parcela foi constituída por 10 plantas. Dessas foram sorteadas quatro plantas e colhidos os frutos maduros localizados em brotações dos primeiros quatro nós. Os frutos de uma mesma planta foram misturados e analisados quanto à pungência. Foi verificada diferença significativa 
em função do ambiente, apenas para nordiidrocapsaicina. As estimativas da variância genética na geração $F_{2}$ apresentaram magnitudes maiores do que as estimativas das variâncias ambientais e da interação genótipo $\mathrm{x}$ ambiente, tanto para as análises individuais dos capsaicinóides avaliados, como para capsaicinóides totais. A interação genótipo $\mathrm{x}$ ambiente foi significativa para todos os capsaicinóides avaliados. Ao analisar a natureza da interação genótipo x ambientes estes pesquisadores verificaram diferenças na magnitude dos dados e alteração na classificação dos genótipos em função do ambiente. Não foi verificado nenhum padrão relacionado à magnitude das médias dos caracteres avaliados e de suas variâncias. Alguns genótipos com alto conteúdo de capsaicinóides apresentaram baixa estimativa de variância dentro dos genótipos, enquanto outros com baixo conteúdo apresentaram variância maior. Quando a variância dentro de genótipos das linhagens duplo-haplóides foi comparada com a variância entre plantas de um mesmo híbrido comercial e de uma mesma cultivar de polinização aberta, verificou-se que a variância de alguns duplo-haplóides e do híbrido foi maior que a da cultivar de polinização aberta. Segundo os pesquisadores, esses resultados indicam uma diferença significativa, nos teores de pungência, quanto à resposta de genótipos de pimenta submetidos a diferentes ambientes.

Zewdie \& Bosland (2000) quantificaram a pungência de frutos localizados em brotações de diferentes nós nas plantas de pimenta e concluíram que os frutos mais pungentes estavam localizados nos primeiros nós. Isso ocorreu provavelmente, devido ao fato de estes frutos receberem maior quantidade de nutrientes, ao contrário dos frutos mais tardios que competem por nutrientes com os que já estão em desenvolvimento na planta. Já Estrada et al. (2002) afirmam o contrário: que os frutos localizados na região apical da planta são os mais pungentes. Isto ocorre porque nas plantas avaliadas em condições de plena produtividade, recebendo adubação adequada, os nutrientes estão igualmente distribuídos entre todos os frutos da planta. Assim, os frutos mais pungentes estão localizados na região apical da planta, provavelmente devido à maior insolação nesta região do que na basal e intermediária. 
Num experimento para verificar a influência da posição dos frutos na planta sobre o conteúdo de capsaicinóides Wagner et al. (2000) avaliaram frutos colhidos em três regiões da planta: basal, intermediária e apical; submetidas a duas condições de insolação: o lado com maior incidência solar e outro com menor incidência. Não foi encontrada diferença significativa na pungência em função da posição dos frutos na planta, provavelmente devido à alta insolação registrada no local da instalação do experimento que deve ter sido suficiente para que os frutos localizados na região basal e intermediária sintetizassem a mesma quantidade de capsaicinóides obtidas pelos frutos localizados na região apical.

Em estudos para identificar a influência de diferentes épocas de plantio e estádio de desenvolvimento de frutos de pimenta do tipo Padrón, Estrada (1999a) concluíram que o acúmulo de capsaicinóides em frutos de pimenta foi altamente sensível a condições ambientais. Nos meses de agosto e setembro (na Espanha), houve considerável aumento dos níveis de capsaicinóides (capsaicina e diidrocapsaicina), especialmente 42 dias após o florescimento. Em outubro, os níveis de capsaicinóides voltaram a diminuir. Esse resultado confirmou que os níveis de capsaicinóides são maiores em frutos de plantas de verão do que nas de outono. Isso, provavelmente, ocorreu devido à existência de uma relação entre pungência, temperatura e luz. Não foi esclarecido qual dos fatores é o mais importante na variação dos níveis de pungência.

Em outro experimento, Estrada (1999b) correlacionaram o efeito da irrigação com vários parâmetros biológicos do metabolismo dos fenilpropanóides e teor de pungência no processo de maturação de frutos. Foi demonstrado que o conteúdo de fenólicos solúveis e lignina foi maior nas plantas controle em relação às plantas que sofreram estresse hídrico. Nas mesmas plantas a pungência aumentou proporcionalmente ao aumento da deficiência de água.

\subsection{Produtividade, espessura da polpa, tamanho do fruto e descritores morfológicos}

Existem poucos estudos sobre produtividade e caracteres primários e secundários relacionados à produção de frutos de pimenta, quando comparados com culturas mais 
estudadas como, por exemplo, aveia, trigo, soja e milho. Poucas, também, são as pesquisas sobre correlação entre caracteres morfológicos e fenológicos e estudos sobre a base genética destes caracteres.

Num estudo de correlação de caracteres relacionados à produção de pimentão, Tavares et al. (1999) concluíram que o caráter com maior efeito positivo sobre o peso total foi o número total de frutos, e que o maior peso total de frutos foi obtido quando estes apresentaram menor largura e maior número de lóculos.

Estudando a heterose em combinações híbridas de $C$. chinense Sousa \& Maluf (2000) demonstraram que esta ocorre nos caracteres matéria seca do fruto, rendimento de capsaicina por planta, número de sementes por fruto e para a relação comprimento/diâmetro do fruto.

Os caracteres: número de frutos por planta, comprimento do fruto, peso de frutos e conteúdo total de capsaicina foram avaliados por Doshi \& Shukla (2000). Os componentes aditivo e dominante foram significativos para todos os caracteres. Sendo que as estimativas do efeito aditivo foram maiores do que as de dominância no comprimento do fruto e no conteúdo de capsaicina, indicando uma preponderância da ação gênica aditiva nesses caracteres. Foi verificada ocorrência de sobredominância para o número de frutos por planta, comprimento e largura do fruto. Este resultado deve ser analisado com ressalvas. Se no somatório dos efeitos aditivos alguns locos apresentarem a mesma magnitude, porém em sentidos opostos (um para o alelo favorável e outro para o desfavorável) tais locos se anularão e o valor estimado desse tipo de efeito será sub-estimado. Portanto a interpretação da sobredominância deve ser cuidadosa. Pode-se afirmar que existe dominância e, provavelmente, ocorra sobredominância. Já para os caracteres peso de fruto e conteúdo de capsaicina foi verificada a ocorrência de dominância parcial.

Ainda neste estudo foram encontrados valores de herdabilidade no sentido restrito de $77 \%, 72 \%, 44 \%, 82 \%$ e $95 \%$ para o número de frutos por planta, comprimento e largura do fruto, peso de frutos e conteúdo total de capsaicina, respectivamente. 
Os mesmos pesquisadores (Doshi \& Shukla, 2000) realizaram análise de capacidade de combinação, utilizando o método 2 , modelo 1 de Griffing e encontraram efeitos significativos para as capacidades geral e específica de combinação, indicando a importância tanto dos efeitos aditivos como dos não aditivos.

Em pesquisa realizada utilizando mapeamento de QTL's (“quantitative trait loci") associados a: peso, diâmetro e comprimento do fruto; espessura da polpa e comprimento do pedicelo, Chaim \& colaboradores (2001) encontraram cinco Qtl's associados a peso do fruto e comprimento do pedicelo e quatro associados aos demais caracteres. Os QTL's explicaram 36\%, 60\%, 48\%, 54\% da variação fenotípica total para peso, diâmetro e comprimento do fruto e espessura da polpa, respectivamente. No mesmo estudo foram estimadas as herdabilidades no sentido restrito, tendo-se obtido os valores: $89 \%, 93 \%, 72 \%, 74 \%, 59 \%$ para peso, diâmetro e comprimento do fruto, espessura da polpa e comprimento do pedicelo, respectivamente.

\subsection{Métodos de análise da pungência}

Em 1912, Scoville desenvolveu uma metodologia de análise sensorial da pungência, sendo sua medida quantificada em unidade Scoville de calor (SHU). Essa é a unidade mais utilizada para expressar a quantidade de pungência. Com o advento de novas tecnologias, técnicas de espectrofotometria e cromatografia foram desenvolvidas e permitiram maior conhecimento sobre as substâncias bioquímicas envolvidas na pungência. Uma das técnicas disponíveis e que apresenta maior precisão na quantificação da pungência é a cromatografia líquida de alta eficiência (CLAE), em que a concentração de uma parte por milhão (ppm) de capsaicinóides corresponde a 15 SHU (Bosland, 1993).

Existem vários métodos cromatográficos para análise de pungência conforme segue: ASTA (1985); Chiang (1986); Attuquayefio \& Buckle (1987); Cooper et al. (1991); Hoffman (1983); Woodbury (1980); Collins (1995) e Parrish (1996). O último foi desenvolvido em um trabalho conjunto de sete laboratórios (Botanicals International; Cal-Compack, Inc.; Certified Laboratories; Gilroy Foods, Inc.; Griffith Laboratories; 
Kalsec Inc. \& McCormick) e adotado como método oficial da AOAC-ASTA International.

\subsection{Melhoramento genético}

O melhoramento genético de Capsicum no Brasil é realizado tanto por empresas públicas como privadas. O maior programa de melhoramento genético voltado para pungência está sendo desenvolvido pela Embrapa Hortaliças. A Embrapa possui linhas de melhoramento genético direcionadas para diferentes nichos de mercado, desenvolvendo cultivares para pequenos e médios produtores e realizando programa de melhoramento em parceria com grandes agroindústrias.

A Embrapa após um esforço coletivo multiinstitucional, obteve avanços significativos para o futuro do melhoramento genético de Capsicum. Foram realizadas: 1) coleta de genótipos silvestres de Capsicum com risco de extinção em regiões em processo de desmatamento; 2) enriquecimento da coleção de germoplasma da Embrapa através de introduções e intercâmbios de genótipos; 3) caracterização morfológica, citológica e molecular (por meio de marcadores RAPD e SSR) da coleção; 4) avaliação da coleção para resistência às principais doenças; 5) incorporação de resistência a doenças em populações em programas específicos de melhoramento e 6) avaliação da efetividade da resistência sob diferentes sistemas de cultivo, com a colaboração de empresas públicas e privadas (Embrapa 2003).

O mercado consumidor de Capsicum é bastante diversificado, existindo mercado tanto para frutos com alta pungência, como para ausência de pungência (pimentões e pimentas doces para consumo in natura e corantes). Dentro do mercado de pimentas com ardor existe uma ampla variação no teor da pungência, variando de pimentas menos pungentes para consumo in natura e desidratadas, às com pungência intermediária para molhos liqüefeitos e páprica picante, até os com alta pungência para conservas e indústria farmacêutica e bélica.

Os programas de melhoramento genético têm obtido ganhos significativos no aumento da pungência, porém em populações segregantes existe grande dificuldade em 
diminuir e eliminar totalmente a pungência dos genótipos (Silva ${ }^{2}$ - Informe pessoal). Outra dificuldade enfrentada pelos melhoristas é a grande influência ambiental, aliada à pouca informação genética disponível sobre a pungência, o que dificulta o processo de seleção e a obtenção de genótipos estáveis (Bosland, 1993).

Os programas de melhoramento genético têm explorado a diversidade genética de Capsicum, principalmente das espécies domesticadas, ou seja: C. annuum, C. chinense, C. baccatum, C. frutenscens. Dentre as cultivares desenvolvidas para o mercado existem: híbridos, linhagens e populações de polinização aberta. As principais características, alvo dos programas de melhoramento são: produtividade, fácil destaque dos frutos durante a colheita, arquitetura de planta, precocidade e resistência a doenças. Paralelamente, são realizadas avaliações para coloração, pungência, sabor, aroma, formato e tamanho de fruto, espessura da polpa e perda de peso pós colheita (Greenleaf, 1986; Reifschneider, 2000).

Os principais métodos de melhoramento genético utilizados são a seleção recorrente, o método genelógico e a produção de híbridos. A seleção recorrente é adotada, principalmente para incorporar resistência múltipla às doenças. O método genealógico é usado em geral para pungência e alguns caracteres do fruto. Como forma de condução dos genótipos dentro dos três métodos de melhoramento mencionados acima, são adotadas estratégias de SSD ("single seed descent"), "bulk" e retrocruzamentos (Saccardo, 1992; Reifschneider, 2000).

As hibridações e auto-fecundações são manuais e as flores protegidas com papel alumínio. Os híbridos comerciais são obtidos por emasculação manual e utilização de linhagens com macho-esterilidade genética e citoplasmática. As linhagens com macho-esterilidade genética foram obtidas por mutantes de ocorrência espontânea, enquanto que a citoplasmática proveio de linhagens identificadas por Peterson (1958) (Calantilles, 2003).

Há perspectivas de que os melhoristas, além de trabalharem com aumento de produtividade e incorporação de resistência a doenças, passem a realizar e/ou utilizar genótipos oriundos de pré-melhoramento e invistam no melhoramento para caracteres de

2 Pesquisadora da Embrapa Hortaliças, 2002. 
qualidade do fruto. Quanto a utilização de genótipos silvestres, é remota a possibilidade de utilização de Capsicum nos programas de melhoramento genético, visto haver ampla variabilidade genética disponível nas espécies domesticadas bem como possibilidade de cruzamentos interespecíficos. 


\section{MATERIAL E MÉTODOS}

Este trabalho foi desenvolvido utilizando linhagens e progênies do programa de melhoramento genético de Capsicum da Embrapa Hortaliças. O estudo objetivou avaliar a variação genética de caracteres importantes para o melhoramento, podendo ser dividido em duas partes, quais sejam: 1) a pungência dos frutos e 2) a produtividade de frutos, o número de frutos por planta, o peso médio, o comprimento e a largura dos frutos e a espessura da polpa.

\subsection{Genótipos utilizados}

A população utilizada no presente estudo foi desenvolvida pelo programa de melhoramento genético de Capsicum da Embrapa Hortaliças. Foi utilizado um cruzamento intraespecífico (Capsicum annuum L.), envolvendo duas linhagens homozigóticas contrastantes para pungência. No cruzamento, os grãos de pólen, do genitor masculino foram coletados de várias plantas e misturados antes da polinização.

O genitor feminino foi o genótipo CNPH 7-P (doce) e o masculino o genótipo CNPH 6-P (pungente). Neste estudo o genitor feminino foi denominado $\mathrm{P}_{1}$ e o masculino $\mathrm{P}_{2}$. As sementes provenientes desse cruzamento deram origem às plantas $\mathrm{F}_{1}$, sendo também obtidas gerações subseqüentes $\left(\mathrm{RC}_{11}\right.$ e $\left.\mathrm{F}_{4}\right)$, como descrito a seguir. Paralelamente, plantas individuais dos genitores foram auto-fecundadas por dois ciclos consecutivos, para multiplicação de sementes, que foram utilizadas na instalação do experimento.

$\mathrm{O}$ retrocruzamento $\left(\mathrm{RC}_{11}\right)$ foi realizado utilizando como genitor recorrente masculino o genótipo CNPH 7-P (P1) e como genitor feminino, planta da geração $\mathrm{F}_{1}$. Assim, $\mathrm{RC}_{11}$ é a primeira geração de retrocruzamento para o genitor com alelos desfavoráveis para pungência (doce). 
A geração $F_{4}$ foi obtida conforme segue: Feito o cruzamento, uma planta da geração $F_{1}$ foi auto-fecundada originando 379 plantas $F_{2}$. Essas, por sua vez, foram autofecundadas novamente, dando origem a 379 distintas progênies $F_{3}$, que foram autofecundadas gerando as progênies $\mathrm{F}_{4}$. Foi mantida a individualidade das plantas e das progênies a partir da geração $\mathrm{F}_{2}$, sendo avançadas para a geração seguinte apenas sementes oriundas de uma única planta. O método de condução utilizado foi o SSD. Foram utilizadas 100 progênies $F_{4}$ distintas. Esse número foi estabelecido em função da exeqüibilidade dos trabalhos, que dependem da área física disponível em telado e do custo das análises cromatográficas.

\subsection{Condução do experimento}

$\mathrm{O}$ delineamento experimental utilizado foi de blocos ao acaso completos, com três repetições e 10 (dez) plantas por parcela. Para os dados de pungência foram analisados 106, 107 e 101 tratamentos, respectivamente nos blocos um, dois e três, conforme Tabela 1.

Tabela 1. Número de parcelas * por geração em cada bloco, utilizados para avaliação da pungência em frutos de pimenta.

\begin{tabular}{lrcc}
\hline \multicolumn{1}{c}{ Gerações } & Bloco I & Bloco II & Bloco III \\
\hline $\mathrm{P}_{1}$ & 3 & 3 & 3 \\
$\mathrm{P}_{2}$ & 2 & 2 & 2 \\
$\mathrm{~F}_{1}$ & 2 & 2 & 2 \\
$\mathrm{RC}_{11}$ & 2 & 2 & 3 \\
$\mathrm{~F}_{4}$ & 97 & 98 & 91 \\
\hline
\end{tabular}

* cada parcela foi constituída por 10 plantas.

Para os dados largura e comprimento dos frutos e espessura da polpa foram tomados dados de 292 parcelas de progênies $F_{4.3}$, nos blocos três blocos (Tabela 2). 
Tabela 2. Número de parcelas e número de plantas amostradas por geração nos três blocos, utilizados para avaliação produtividade, número de frutos, peso médio do fruto, largura e comprimento do fruto e espessura de polpa em frutos de pimenta.

\begin{tabular}{lcc}
\hline Gerações & Parcelas & Plantas \\
\hline $\mathrm{P}_{1}$ & 8 & 40 \\
$\mathrm{P}_{2}$ & 5 & 25 \\
$\mathrm{~F}_{1}$ & 6 & 30 \\
$\mathrm{RC}_{11}$ & 9 & 45 \\
$\mathrm{~F}_{4}$ & 292 & 1460 \\
\hline
\end{tabular}

As parcelas constituíram-se de duas fileiras de 1,5 metros de comprimento cada, sendo cada fileira constituída por cinco plantas. Ao redor dos tratamentos de cada repetição foi plantada bordadura com Capsicum annuum L.

Todas as parcelas de todos os tratamentos foram ordenadas e numeradas em ordem crescente. Essa numeração foi utilizada no sorteio das parcelas, sendo que para cada bloco foi realizado um sorteio diferente. O sorteio das parcelas foi feito com o auxílio de uma tabela de números aleatórios, gerada pelo programa computacional Excel (Microsoft, Office 2000). Com base no resultado do sorteio e da área física disponível em telado, para cada bloco, foi criado um mapa de plantio.

O experimento foi instalado no $2^{0}$ semestre de 2002, na Embrapa Hortaliças, localizada no km 09 da BR 06 - rodovia Brasília/Anápolis. A Embrapa fica situada à latitude sul $15^{0} 56^{\prime} 00^{\prime \prime}$, longitude oeste $48^{0} 08^{\prime} 00^{\prime \prime}$ e altitude de 997,62 metros.

As progênies $F_{4}$ e as gerações $P_{1}, P_{2}, F_{1}$ e $R_{11}$ foram semeadas em bandeja, contendo substrato comercial e transplantadas para telado quando atingiram entre 4 a 8 folhas definitivas. Foi utilizado espaçamento de $1 \mathrm{~m}$ entre linhas e 0,30 $\mathrm{m}$ entre plantas na linha nos blocos I e III; e 0,70 m x 0,30 m no bloco II. Foi adotado sistema de irrigação por gotejamento e manejo fitotécnico e sanitário recomendado para cultivo protegido de Capsicum (Embrapa, 2003). 


\subsection{Pungência}

Com o objetivo de obter amostras de frutos de pimenta para quantificação da pungência, flores de todas as plantas de cada parcela foram marcadas na antese (outubro de 2002). Após trinta dias foram colhidos e marcados cinco frutos por planta em todos os tratamentos, totalizando 50 frutos por parcela e, aproximadamente, 5500 frutos por bloco. Isso foi feito para garantir que todos os frutos colhidos tivessem a mesma idade.

Para a obtenção do extrato etanólico contendo os capsaicinóides, os frutos foram identificados, mantendo a individualidade por planta. Após secagem e moagem dos frutos, foi composta uma amostra aleatória para cada parcela. Essa foi constituída por duas gramas de fruto seco de cada planta, resultando em, aproximadamente, 20 gramas de pimenta seca por parcela, dos quais foram utilizados 12,5 gramas para a extração dos capsaicinóides. Em algumas parcelas os frutos, após secos, não atingiram 12,5 gramas, estando a quantidade avaliada em gramas por parcela no Anexo A.

Esta metodologia foi adotada, pois neste estudo realizou-se a quantificação da pungência com base na média de parcela. Foram tomados cuidados para que a amostragem dos frutos fosse representativa e expressasse a média dos genótipos para a característica avaliada.

A quantificação da pungência foi realizada através do método de Parrish (1996) de análise de cromatografia líquida de alta eficiência (CLAE). As amostras foram secas a $60^{\circ} \mathrm{C}$ em estufa, com aeração, por $24 \mathrm{~h}$, moídas e submetidas à extração, sob refluxo com etanol, por $5 \mathrm{~h}$. A quantificação foi feita utilizando solução padrão, contendo $0,3 \mu \mathrm{g}$ de $\mathrm{N}$-vanililanonanamida $(\mathrm{NVN})$ em $20 \mu \mathrm{l}$ de solução etanólica. A coluna empregada foi Nucleosil C-18, 150 x 4,6 mm de diâmetro interno, partícula de $5 \mu \mathrm{m}$ e, como fase móvel, uma mistura 4:6 de acetonitrila e solução aquosa a 1\% de ácido acético. A leitura no detector de UV foi ajustada para 280 nanômetros (nm). Os valores de concentração da capsaicina, diidrocapsaicina e nordiidrocapsaicina foram utilizados para determinar a média de pungência em unidade Scoville de calor (SHU).

Com os dados obtidos na quantificação da pungência foram realizadas: 1) análise exploratória dos dados, através de histogramas de distribuição de frequiências; 2) análise 
de variância; 3) componentes de média e 4) análise de correlação, conforme descrito a seguir.

\subsubsection{Histogramas de distribuição de freqüência da pungência}

Os histogramas de freqüência foram construídos para a realização de uma análise exploratória dos dados, com o intuito de visualizar o comportamento das médias e da distribuição da pungência nas diferentes gerações. Foram feitos histogramas para nordiidrocapsaicina, capsaicina, diidrocapsaicina e capsaicinóides totais.

Os intervalos de classe foram obtidos baseado nas fórmulas:

$$
\begin{aligned}
& \mathrm{i}=\frac{\mathrm{A}}{\mathrm{k}} \\
& \mathrm{k}=\sqrt{\mathrm{n}}
\end{aligned}
$$

$\mathrm{i}=$ intervalo de classe;

A = amplitude de variação entre o máximo e o mínimo;

$\mathrm{k}=$ número de classes;

$\mathrm{n}=$ número de observações.

Paralelamente, os genótipos foram divididos em pungentes e doces e testadas as hipóteses de segregação fenotípica (pungentes: doces) de 3:1 e 9:7, respectivamente. As hipóteses foram sugeridas em função dos dados existentes na literatura (Deshpande, 1935; Zewdie \& Bosland, 2000a) e testadas pelo teste do qui-quadrado (Steel \& Torrie, 1971). Tais hipóteses se aplicam estritamente a uma geração $F_{2}$. Neste trabalho, no entanto, essas proporções foram estendidas à geração $F_{4}$ pois, as progênies $F_{4.3}$ estudadas foram obtidas pelo método SSD. Sabe-se que as referidas proporções não deverão ser reproduzidas exatamente na geração $\mathrm{F}_{4}$, devido à amostragem inerente ao SSD. Biometricamente, porém não é possível corrigi-las devido à natureza aleatória do processo. Foram, mesmo assim, usadas por serem a melhor opção para o caso.

\subsubsection{Análise de variância da pungência}

As análises de variância dos dados experimentais de pungência foram utilizados neste estudo com o objetivo de obter as estimativas dos componentes de variância, herdabilidade e ganho genético com seleção para os diferentes capsaicinóides e capsaicinóides totais. 
O quadrado médio residual (QMR) é, evidentemente, fundamental para obter as estimativas dos parâmetros genéticos mencionados no item 3.3.3. Devido à natureza contrastante dos genótipos (tratamentos) avaliados, optou-se pelo cálculo de QM residuais específicos, o que significou fazer três análises. Assim, obteve-se um QMR somente com as parcelas das progênies $\mathrm{F}_{4}$, outro com as parcelas contendo as gerações $\mathrm{P}_{1}, \mathrm{P}_{2}$ e $\mathrm{F}_{1}$ e um terceiro QMR envolvendo todas as parcelas.

Para a realização das análises foi utilizado o programa de análise estatística SAS (Statistic Analysis System, 1998), sendo adotado o procedimento "proc glm". Utilizando o mesmo programa, com os procedimentos adequados, foram verificadas as pressuposições do modelo da análise de variância.

$\mathrm{O}$ número de graus de liberdade de progênies $\mathrm{F}_{4}$, resíduo e totais sofreram alterações pelo fato de os dados estarem desbalanceados. O número de médias de parcelas analisadas encontra-se na Tabela 1 (item 3.2). Os dados utilizados na análise encontram-se no Anexo B e os protocolos de análise no Anexo C. O esquema padrão de análise de variância, balanceada, para um só dado por parcela, utilizado para avaliação dos dados de pungência encontra-se na Tabela 3. O efeito de gerações foi considerado fixo e os demais efeitos aleatórios.

A esperanças matemática dos quadrados médios foi obtida pela metodologia exposta por Barbin (1998). As componentes da variância foram estimadas pelo método dos momentos.

Tabela 3. Esquema de análise da variância de médias de parcelas, com fontes de variação (FV), graus de liberdade (GL), quadrados médios (QM) e esperanças dos quadrados médios [E(QM)]. Dados de pungência.

\begin{tabular}{lccl}
\hline \multicolumn{1}{c}{ FV } & GL & QM & E(QM) \\
\hline Blocos & $\mathrm{R}-1$ & QM1 & \\
Gerações & $\mathrm{G}-1$ & QM2 & \\
Progênies $\mathrm{F}_{4.3}$ & $\mathrm{~T}-1$ & $\mathrm{QM} 3$ & $\sigma^{2}+\mathrm{R} \sigma_{\mathrm{p}}^{2}$ \\
Resíduo & $\mathrm{n}$ & $\mathrm{QM} 4$ & $\sigma^{2}$ \\
& & & \\
Totais & $\mathrm{N}-1$ & & \\
\hline
\end{tabular}


$\mathrm{R}$ = número de blocos;

$\mathrm{G}=$ número de gerações;

$\mathrm{C}=$ número de parcelas repetidas de uma dada geração, por bloco;

$\mathrm{T}=$ número de progênies $\mathrm{F}_{4}$;

$\mathrm{N}=$ número total de dados: $\mathrm{N}=[\mathrm{T}+\mathrm{C}(\mathrm{G}-1)] \mathrm{R}$;

$\mathrm{n}=(\mathrm{G}-1)(\mathrm{R}-1)+\mathrm{R}(\mathrm{C}-1)(\mathrm{G}-1)+(\mathrm{T}-1)(\mathrm{R}-1) ;$

Número de parcelas por bloco: $\mathrm{T}+\mathrm{C}(\mathrm{G}-1)$.

As estimativas das variâncias genética e residual foram obtidas pelas expressões:

$$
\begin{aligned}
& \hat{\mathrm{O}}_{\mathrm{p}}^{2}=\frac{\mathrm{QM} 3-\mathrm{QM} 4}{\mathrm{R}} \\
& \hat{\mathrm{O}}^{2}=\mathrm{QM} 4^{\prime}
\end{aligned}
$$

Sendo: QM4'o quadrado médio do resíduo da análise de variância contendo apenas os dados da geração $\mathrm{F}_{4}$.

A herdabilidade no sentido amplo com base nas médias de parcelas, foi estimada conforme segue:

$$
\hat{\mathrm{h}}_{\mathrm{m}}^{2}=\frac{\hat{\boldsymbol{\sigma}}_{p}^{2}}{{\hat{\hat{o}_{\mathrm{p}}}}^{2}+\frac{{\hat{\hat{o}^{\prime}}}^{2}}{\mathrm{R}}}
$$

Na eq. (5) o denominador é a estimativa da variância fenotípica entre médias de progênie $\mathrm{F}_{4}$, que é estimável por QM3 / R.

Considerando que as progênies $F_{4.3}$ provieram da auto-fecundação de plantas $F_{3}$ mantendo a individualidade das plantas, pelo processo SSD, o significado das variâncias de natureza genética desta pesquisa pode ser expresso como segue (Vencovsky \& Barriga, 1992; Souza, Jr., 1989). Na notação usada a seguir, $\sigma_{\mathrm{A}}^{2}$ e $\sigma_{\mathrm{D}}^{2}$ representam as variâncias aditiva e dominante, respectivamente. Por simplicidade não serão incluídas as variâncias epistáticas. 
Variância genética total em $\mathrm{F}_{4}$ :

$$
\begin{aligned}
& \text { ó }_{\mathrm{G}}^{2}=\left(1+\frac{3}{4}\right) \hat{o}_{\mathrm{A}}^{2}+\left[1-\left(\frac{3}{4}\right)^{2}\right] \mathrm{o}_{\mathrm{D}}^{2} \\
& \text { Ó }_{\mathrm{G}}^{2}=\frac{7}{4} \text { ó }_{\mathrm{A}}^{2}+\frac{7}{16} \text { ó }_{\mathrm{D}}^{2}
\end{aligned}
$$

Variância genética entre progênies $\mathbf{F}_{4: 3}$ :

$$
\begin{aligned}
& \hat{\mathrm{O}}_{\mathrm{p}}^{2}=\left(1+\frac{1}{2}\right) \hat{\sigma}_{\mathrm{A}}^{2}+\frac{1+\frac{1}{2}}{1-\frac{1}{2}}\left(1-\frac{3}{4}\right)\left(1-\frac{3}{4}\right) \hat{\sigma}_{\mathrm{D}}^{2} \\
& \mathbf{O}_{\mathrm{p}}^{2}=\frac{3}{2} \mathrm{o}_{\mathrm{A}}^{2}+\frac{3}{16} \sigma_{\mathrm{D}}^{2}
\end{aligned}
$$

\section{Variância genética dentro de progênies $\mathbf{F}_{4: 3}$ :}

$$
\text { Ó }_{\mathrm{gd}}^{2}=\frac{1}{4} \text { ó }_{\mathrm{A}}^{2}+\frac{1}{4} \text { ó }_{\mathrm{D}}^{2}
$$

Convém ressaltar que as expressões dadas de $\sigma_{p}^{2}$ e $\sigma_{\text {gd }}^{2}$ refere-se estritamente a progênies $\mathrm{F}_{4}$ abertas numa população $\mathrm{F}_{3}$, esta última gerada em "bulk" a partir de $\mathrm{F}_{2}$. No caso do método SSD, no entanto essas variâncias são ligeiramente alteradas devido à amostragem. Conforme Vencovsky (informe pessoal, 2003) os conteúdos sob SSD são:

$$
\begin{aligned}
& \text { Ó }_{\mathrm{p}}^{2}=\frac{11}{8} \mathrm{ó}_{\mathrm{A}}^{2}+\frac{5}{32} \mathrm{ó}_{\mathrm{D}}^{2} \\
& \text { ó }_{\mathrm{gd}}^{2}=\frac{3}{8} o_{\mathrm{A}}^{2}+\frac{7}{32} o_{\mathrm{D}}^{2}
\end{aligned}
$$


Essas discrepâncias, sendo pequenas não alteram substancialmente as estimativas do progresso genético esperado.

É preciso ressaltar, também, que um coeficiente de herdabilidade no sentido restrito, ou seja, $h^{2}=\sigma_{\mathrm{A}}^{2} / \sigma_{\mathrm{F}}^{2}$ (sendo $\sigma_{\mathrm{F}}^{2}$ a variância fenotípica do caráter) não é estimável com dados como os obtidos no caso da pungência, em que se trabalhou só com médias de parcela e se avaliou uma só geração. O coeficiente aqui utilizado [eq. (5)], superestima $\mathrm{h}^{2}$ mas, mesmo assim, pode ser empregado para estimar o progresso esperado com a seleção, desde que se reconheça seu viés.

Na obtenção do progresso esperado pela seleção, o método seletivo considerado é o de uma seleção das progênies $\mathrm{F}_{4: 3}$ superiores e multiplicação das respectivas sementes remanescentes por sucessivas auto-fecundações. Nesses termos o ganho seletivo $\left(\mathrm{G}_{\mathrm{s}}\right)$ pode ser estimado por:

$$
\begin{aligned}
& \hat{\mathrm{G}}_{\mathrm{s}}=\mathrm{ds}\left(\hat{\mathrm{h}}_{\mathrm{m}}^{2}\right) \\
& \mathrm{ds}=\overline{\mathrm{Y}}_{\mathrm{s}}-\overline{\mathrm{Y}}_{0}
\end{aligned}
$$

Sendo ds o diferencial de seleção calculado por:

$\overline{\mathrm{Y}}_{\mathrm{S}}=$ médiageraldas progênies selecionadas.

$\overline{\mathrm{Y}}_{0}=$ médiageralde todasas progêniesavaliadas.

Foram utilizadas pressões de seleção de 5\%, $10 \%$ e $20 \%$ no sentido de aumentar e diminuir o caráter.

Convém lembrar que este progresso, em realidade, é função direta da covariância genética entre as observações feitas nas progênies $\mathrm{F}_{4.3}$ e o valor genotípico das linhagens homozigóticas que surgirão após as auto-fecundações. Esta covariância, no entanto, é obtida conforme descrito por Vencovsky \& Barriga (1992):

$$
\mathrm{C}_{34 \infty}=\left(1+\frac{1}{2}\right) \dot{o}_{\mathrm{A}}^{2}=\frac{3}{2} \hat{o}_{\mathrm{A}}^{2}
$$


Considerando o processo SSD, essa covariância é ligeiramente alterada e passa a ser $(11 / 8) \sigma_{\text {A. }}^{2} \mathrm{O}$ estimador do ganho $\left(\mathrm{G}_{\mathrm{s}}\right)$ tem pois um viés para mais de:

$$
\frac{\left(\frac{5}{32}\right) \hat{o}_{\mathrm{D}}^{2}}{\mathrm{o}_{\mathrm{F}}^{2}}=\frac{0,156 o_{\mathrm{D}}^{2}}{\sigma_{\mathrm{F}}^{2}}
$$

No caso dos dados da pungência o viés não pode ser corrigido, neste trabalho.

\subsubsection{Componentes de média da pungência}

Foi realizada a análise dos componentes genéticos de médias com o objetivo de conhecer as magnitudes e o comportamento dos efeitos gênicos envolvidos na expressão da pungência.

Foram estimados a média geral [m], o somatório dos efeitos de aditividade [a] e dominância [d], usando o método de escala conjunta proposto por Cavali e descrito por Mather e Jinks (1981), baseado nas médias esperadas do caráter para as gerações, desconsiderando os efeitos epistáticos, conforme proposto pelos últimos autores, ou seja:

$$
\begin{aligned}
& \mathrm{E}\left[\overline{\mathrm{Y}}_{(\mathrm{P} 1)}\right]=\mathrm{m}-[\mathrm{a}] \\
& \mathrm{E}\left[\overline{\mathrm{Y}}_{(\mathrm{P} 2)}\right]=\mathrm{m}+[\mathrm{a}] \\
& \mathrm{E}\left[\overline{\mathrm{Y}}_{(\mathrm{F} 1)}\right]=\mathrm{m}+[\mathrm{d}] \\
& \mathrm{E}\left[\overline{\mathrm{Y}}_{(\mathrm{RC} 11)}\right]=\mathrm{m}-(1 / 2)[\mathrm{a}]+(1 / 2)[\mathrm{d}] \\
& \mathrm{E}\left[\overline{\mathrm{Y}}_{(\mathrm{F} 4)}\right]=\mathrm{m}+(1 / 8)[\mathrm{d}] \\
& \text { sendo: } \mathrm{m}=\text { média geral do caráter; } \\
& \qquad \mathrm{a}=\text { somatório dos efeitos aditivos; } \\
& \quad \mathrm{d}=\text { somatório dos efeitos de dominância; } \\
& \mathrm{E}[\overline{\mathrm{Y}}]=\text { esperança matemática da média das gerações } \mathrm{P}_{1}, \mathrm{P}_{2}, \mathrm{~F}_{1}, \mathrm{RC}_{11} \mathrm{e} \\
& \quad \mathrm{F}_{4} .
\end{aligned}
$$

Admitindo que a maioria dos genes favoráveis para as características estudadas estão acumuladas em uma das linhagens genitoras e os desfavoráveis na outra e que as médias esperadas são expressáveis conforme acima, é possível estimar os efeitos de m, 
[a] e [d] considerando as médias das diversas gerações. Foi utilizado o método dos quadrados mínimos ponderados, visto que as médias das diversas gerações não foram obtidas com a mesma precisão experimental.

O fator de ponderação adotado foi o inverso da variância da média das gerações nos três blocos, neste caso representada pelo quadrado médio do resíduo da análise de variância dividido pelo número de dados de cada uma. Para a geração $\mathrm{F}_{4}$ foi utilizado o QMR da análise de variância apenas dos dados das progênies $F_{4}$. Enquanto que para as gerações $\mathrm{P}_{1}, \mathrm{P}_{2}$ e $\mathrm{F}_{1}$ foi usado o $\mathrm{QMR}$ da análise contendo apenas os dados dessas gerações. Isso foi necessário, pois a natureza da variação desses dados é ambiental nas três gerações. Já para a geração $\mathrm{RC}_{11}$ foi utilizado o QMR obtido da análise de variância contendo todos os dados de todas as gerações. Essas variâncias foram, portanto, divididas por 9, 6, 6, 7 e 286, que correspondem ao número de parcelas avaliadas, para $\mathrm{P}_{1}, \mathrm{P}_{2}, \mathrm{~F}_{1}, \mathrm{RC}_{11}$ e $\mathrm{F}_{4}$, respectivamente. Esta adaptação no método de ponderação ocorreu devido ao fato de a análise ser realizada utilizando médias de parcelas.

A adequação do modelo genético aditivo-dominante, adotado com base nos três parâmetros: $\mathrm{m}$, [a] e [d] foi verificada pelo teste de qui-quadrado $\left(\chi^{2}\right)$, em que um valor significativo de $\chi^{2}$ indica a não adequação das médias das gerações do caráter em estudo ao modelo. Caso isso ocorra, o efeito epistático do tipo aditivo $\mathrm{x}$ aditivo [i] foi incluído no modelo para fins de novo cálculo do método de escala conjunta, sendo as esperanças matemáticas das médias de $\mathrm{P}_{1}$ e $\mathrm{P}_{2}$ representadas por: $\mathrm{m}$ - [a] + [i] e $\mathrm{m}+[\mathrm{a}]+[\mathrm{i}]$, respectivamente e de $\mathrm{RC}_{11}=\mathrm{m}-(1 / 2)[\mathrm{a}]+(1 / 2)[\mathrm{d}]+(1 / 4)$ [i]. Para as demais gerações não há alteração nas esperanças matemáticas das médias do caráter, em relação ao teste de escala conjunta na ausência de epistasia.

\subsubsection{Análise de correlação}

Com o objetivo de comparar a eficiência da quantificação da pungência através do método cromatográfico (CLAE) com o método sensorial aplicado aos frutos e ao extrato etanólico, contendo capsaicinóides, foi realizada análise de correlação simples de Person, entre as médias das progênies $\mathrm{F}_{4.3}$. 
Um fruto de cada parcela foi avaliado sensorialmente e classificado em duas classes - doce (0) e pungente (1). No caso do fruto ser doce, outros frutos da parcelas também foram avaliados, com a finalidade de confirmar a ausência de pungência. Da mesma forma os extratos etanólicos foram classificados também, nas mesmas duas classes. Foi calculada uma média de parcelas de cada progênie, dos genitores e das gerações $\mathrm{RC}_{11}$ e $\mathrm{F}_{1}$, nos três blocos, para os dados das duas avaliações. Os dados das análises sensoriais do fruto e do extrato etanólico foram então correlacionados com as médias de capsaicinóides totais, das progênies, dos genitores e das gerações $\mathrm{RC}_{11}$ e $\mathrm{F}_{1}$, obtidas da quantificação da pungência (item 3.3).

Para análise de correlação foi adotado o procedimento "proc corr" do aplicativo computacional de análise de dados (Statistic Analysis System, 1998).

\subsection{Produtividade e demais caracteres do fruto}

Para todos os caracteres estudados, foram realizadas avaliações com base em frutos por planta de todos os tratamentos. As plantas utilizadas neste estudo foram as mesmas avaliadas quanto à pungência. Todas as análises estatísticas foram feitas com base em um só dado por parcela.

Produtividade - 70 dias após a antese sortearam-se cinco plantas de cada parcela e colheram-se todos os frutos de cada uma separadamente. Esses foram pesados utilizando balança digital com precisão de duas casas decimais. Com os dados obtidos calculou-se a produtividade média por planta, em cada parcela.

Número de frutos por planta - esta variável foi quantificada utilizando as mesmas plantas do item anterior, dividindo-se o número total de frutos colhidos pelo número de plantas sorteadas.

Peso médio do fruto - para essa variável a produtividade total das plantas sorteadas foi dividida pelo número total de frutos, em cada parcela.

Largura do fruto - Em cada planta utilizada nos itens anteriores tomaram-se cinco frutos ao acaso e a medida da largura foi feita na maior largura da seção transversal do fruto. Com essas medidas calculou-se a média do comprimento, por parcela. 
Comprimento do fruto - nesse caso utilizaram-se os mesmos frutos do item anterior e o comprimento foi aferidos, utilizando régua milimetrada. A mensuração foi realizada da inserção do pedúnculo até a ponta do fruto.

Espessura média da polpa - para esta variável foram considerados os mesmos cinco frutos avaliados quanto à largura e o comprimento do fruto. Para fazer as medidas usou-se paquímetro. Os frutos foram cortados no sentido transversal, aproximadamente $0,5 \mathrm{~cm}$ abaixo da inserção do pedúnculo e realizada a medição da espessura da polpa.

\subsubsection{Histogramas de distribuição de freqüência dos dados de produtividade e demais caracteres do fruto}

Foram construídos histogramas de distribuição de frequiência conforme descrito no item 3.3.1.

\subsubsection{Análises estatísticas dos dados de produtividade e demais caracteres do fruto}

Os dados médios das parcelas foram submetidos à análise da variância conforme descrito no item 3.3.2. Para obter as estimativas de componentes da variância e do coeficiente de herdabilidade procedeu-se também como exposto naquele item.

\subsubsection{Componentes de média da produtividade e demais caracteres do fruto}

Foram estimados a média geral [m], o somatório dos efeitos de aditividade [a] e dominância [d] com base no método de escala conjunta proposto por Cavali e descrito por Mather e Jinks (1981) e detalhado no ítem 3.3.3.

3.4.4 Resposta correlacionada à seleção para pungência, sobre a produtividade e demais caracteres do fruto

Com a finalidade de verificar quanto uma seleção, visando o aumento da pungência, poderia afetar os caracteres dos frutos calculou-se medida da resposta 
correlacionada com a seleção $\left(\mathrm{RC}_{\mathrm{s}}\right)$. Essa quantidade foi obtida pela expressão genérica dada a seguir e descrita por Vencovsky \& Barriga (1992).

$$
\mathrm{RC}_{\mathrm{s}(2,1)}=(\hat{\mathrm{ds}})_{(2,1)} \cdot \hat{\mathrm{h}}_{\mathrm{m}(2)}^{2}
$$

sendo $\mathrm{h}_{\mathrm{m}(2)}^{2}$ o coeficiente de herdabilidade de um caráter qualquer (largura, comprimento e espessura), $\mathrm{ds}_{(2,1)}$ o diferencial de seleção resultante no caráter (2) quando a seleção é feita no caráter principal (1), no caso a pungência. Esse diferencial é $\mathrm{ds}_{(2,1)}=\overline{\mathrm{Y}}_{\mathrm{s}(2,1)}-\overline{\mathrm{Y}}_{\mathrm{o} 2}$ em que $\overline{\mathrm{Y}}_{\mathrm{s}(2,1)}$ é a medida do caráter (2) nas progênies selecionadas para pungência (caráter 1) e $\bar{Y}_{\mathrm{o} 2}$ a média geral de todas as progênies $\mathrm{F}_{4.3}$, relativamente ao caráter (2). Como no caso da pungência, considerou-se somente a seleção entre progênies para estimar a resposta correlacionada (RCs). 


\section{RESULTADOS}

\subsection{Análises cromatográficas}

Como resultado das análises cromatográficas os genótipos doces não apresentaram nenhum pico, no comprimento de onda de $280 \mathrm{~nm}$, conforme verificado na Figura 2. Já os genótipos pungentes apresentaram de um a três picos correspondentes a nordiidrocapsaicina, capsaicina e diidrocapsaicina (Figura 2), bastando apresentar um dos três picos para o genótipo ser considerado pungente. Em algumas amostras, foi encontrado um pico não identificado entre a capsaicina e a diidrocapsaicina (Figura 1). Alguns genótipos apresentaram apenas este pico (Figura 2). Os frutos e o extrato etanólico dessas amostras ora eram pungentes, ora doces. Assim, tal pico foi desconsiderado na quantificação da pungência.

\subsection{Histogramas dos dados de pungência}

Conforme observado nas Figura 3 a 6, para todos os capsaicinóides analisados ocorreu segregação transgressiva quanto à pungência, em direção ao genitor $\mathrm{P}_{2}$ (pungente). Os valores de pungência da geração $\mathrm{RC}_{11}$ ficaram entre os genitores e mais próximos do genitor $\mathrm{P}_{1}$ (genitor recorrente). Os valores da geração $F_{1}$ foram superiores às dos genitores, porém mantiveram-se dentro da amplitude de variação da geração $\mathrm{F}_{4}$. $\mathrm{O}$ número de progênies pungentes foi superior às doces.

Nos histogramas (Figuras 3 a 6) verifica-se que, em todos os capsaicinóides a média da geração $\mathrm{RC}_{11}$ foi superior à da $\mathrm{F}_{4}$. Exceção feita à nordiidrocapsaicina cujas médias de $\mathrm{RC}_{11}$ e $\mathrm{F}_{4}$ foram de $383 \mathrm{SHU}$ e $433 \mathrm{SHU}$, respectivamente. 


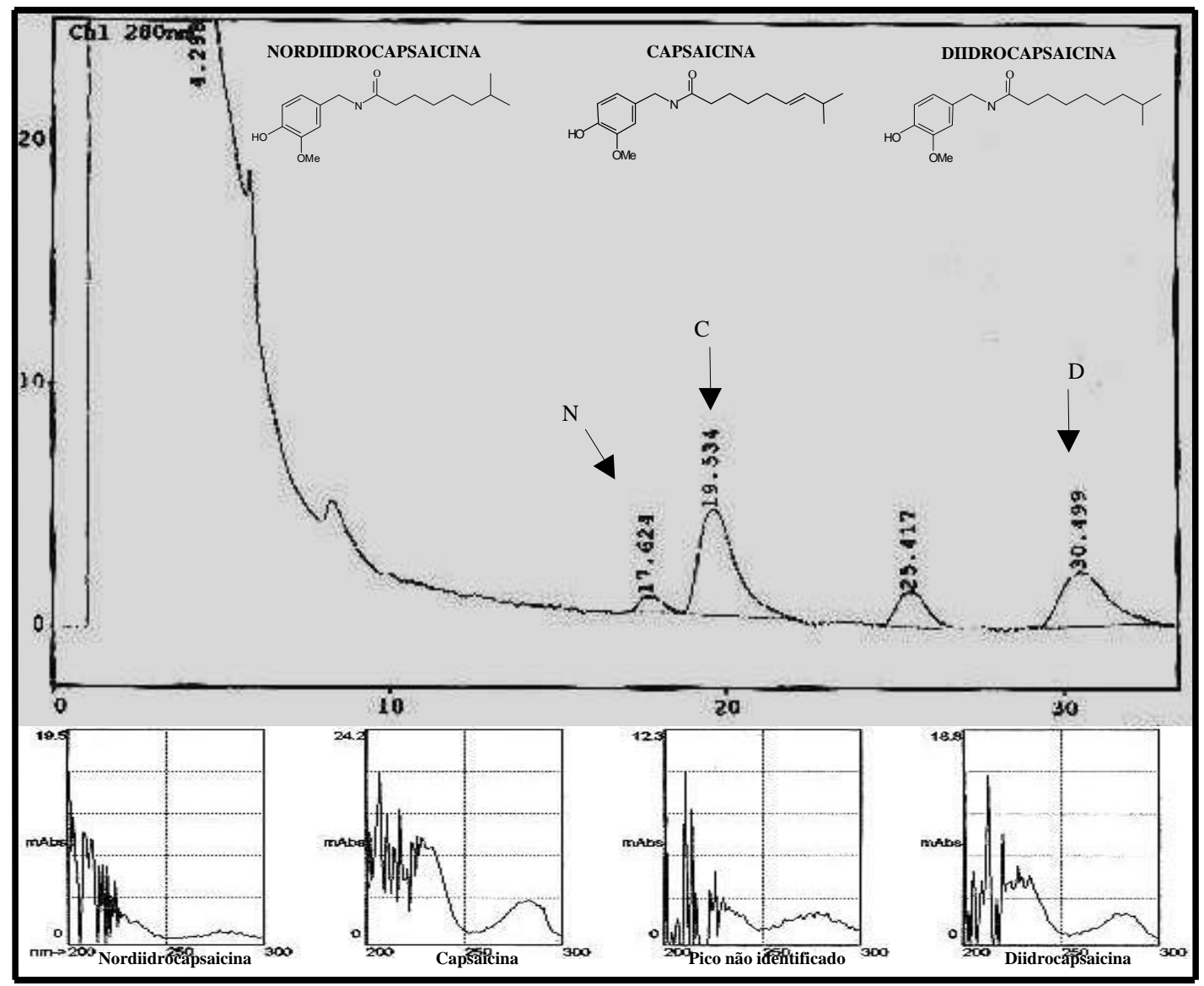

Figura 1-Cromatograma da nordiidrocapsaicina, capsaicina, pico não identificado e diidrocapsaicina com o tempo de retenção em minutos no eixo do $\mathrm{X}$ e a miliabsorbância (mAbs) no eixo $\mathrm{Y}$; e os perfis dos espectros (nanômetro no eixo $\mathrm{X}$ e mAbs no $\mathrm{Y}$ ). Capsicum annuum L. 2002.

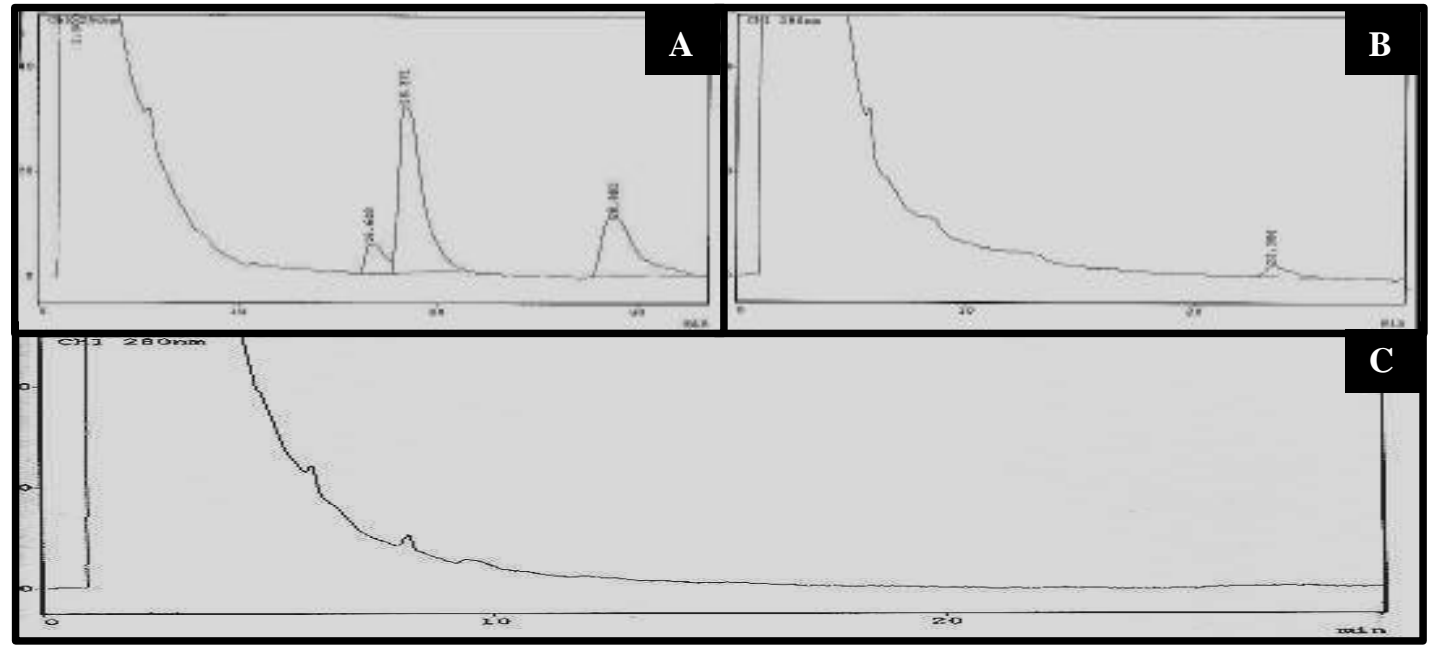

Figura 2-A) Cromatograma com os picos da nordiidrocapsaicina, capsaicina e diidrocapsaicina, respectivamente; B) cromatograma com o pico não identificado; C) cromatograma de um genótipo doce. Capsicum annuum L. 2002. 


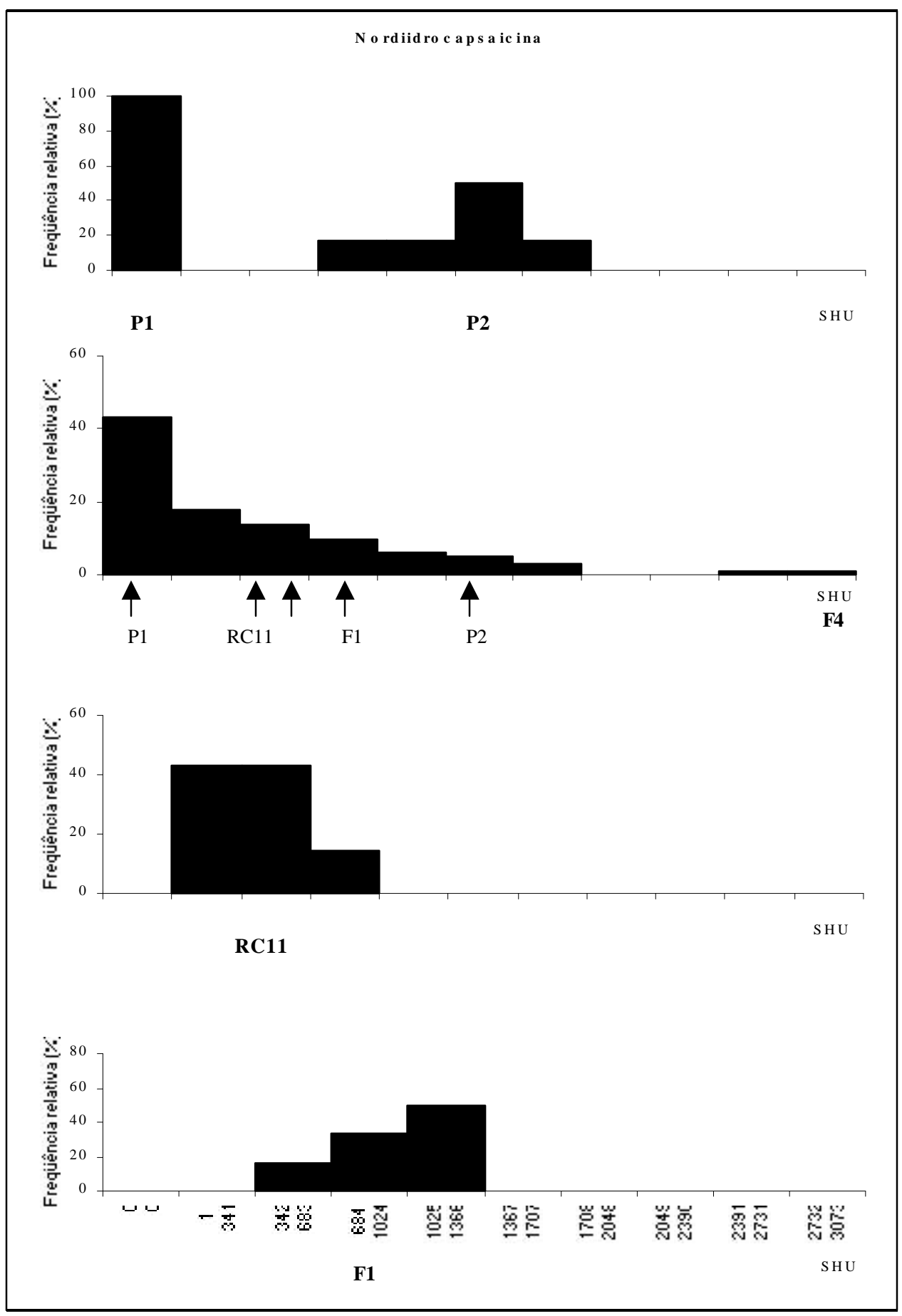

Figura 3 - Histograma de distribuição de frequiência das análises de nordiidrocapsaicina, em unidade Scoville de calor (SHU) das gerações $\mathrm{P}_{1}$, $\mathrm{P}_{2}, \mathrm{~F}_{1}, \mathrm{RC}_{11}$ e $\mathrm{F}_{4}$, com as médias das erações plotadas na base do gráfico da geração $\mathrm{F}_{4}$. Capsicum annuum L. 2002. 


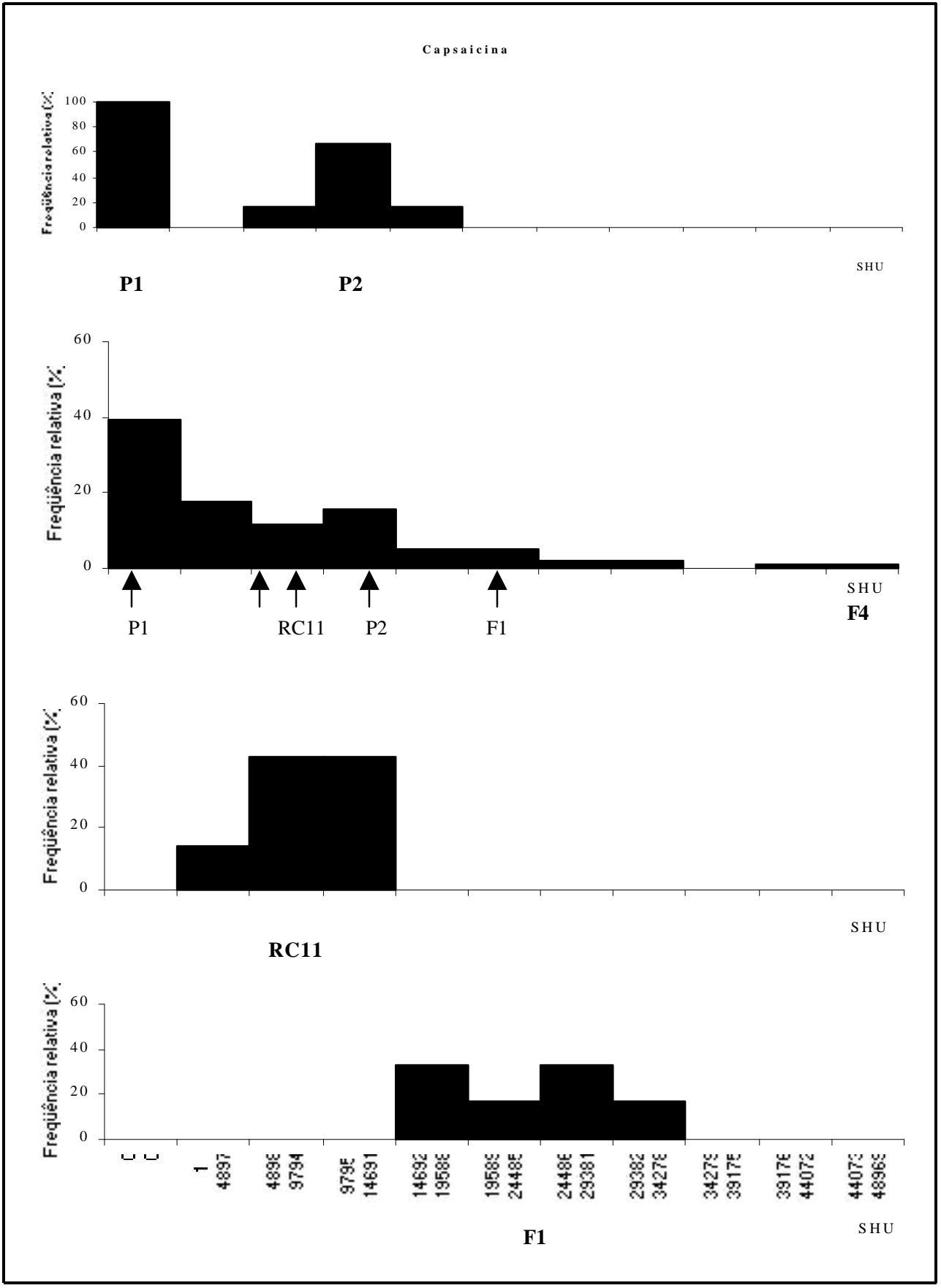

Figura 4-Histograma de distribuição de frequiência das análises de capsaicina, em unidade Scoville de calor ( $\mathrm{SHU}$ ) das gerações $\mathrm{P}_{1}, \mathrm{P}_{2}, \mathrm{~F}_{1}, \mathrm{RC}_{11}$ e $\mathrm{F}_{4}$, com as médias das gerações plotadas na base do gráfico da geração $\mathrm{F}_{4}$. Capsicum aпnиит L. 2002. 


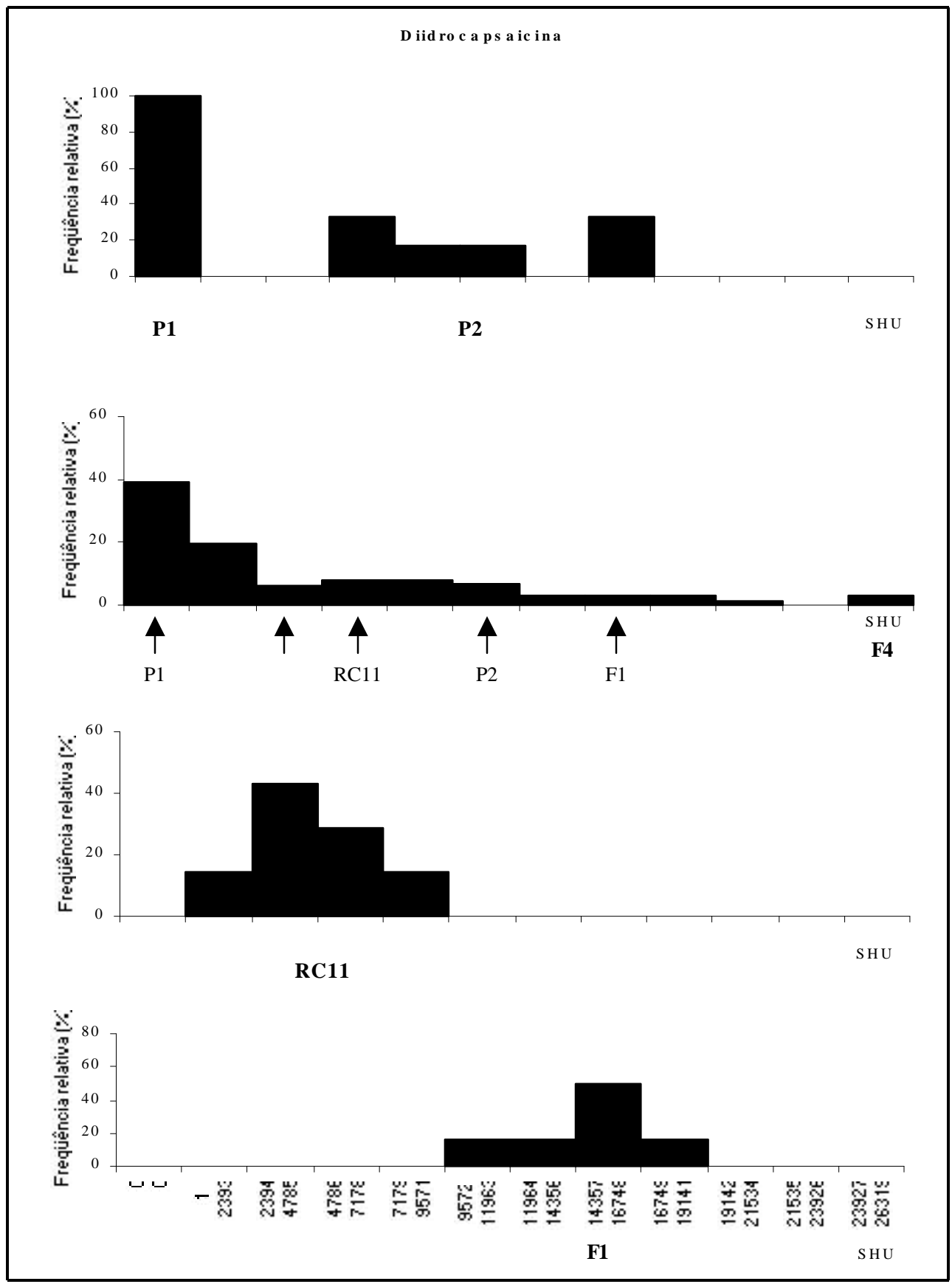

Figura 5-Histograma de distribuição de freqüência das análises de diidrocapsaicina, em unidade Scoville de calor (SHU) das gerações $\mathrm{P}_{1}, \mathrm{P}_{2}, \mathrm{~F}_{1}, \mathrm{RC}_{11}$ e $\mathrm{F}_{4}$, com as médias das gerações plotadas na base do gráfico da geração $\mathrm{F}_{4}$. Capsicum аппиит L. 2002. 


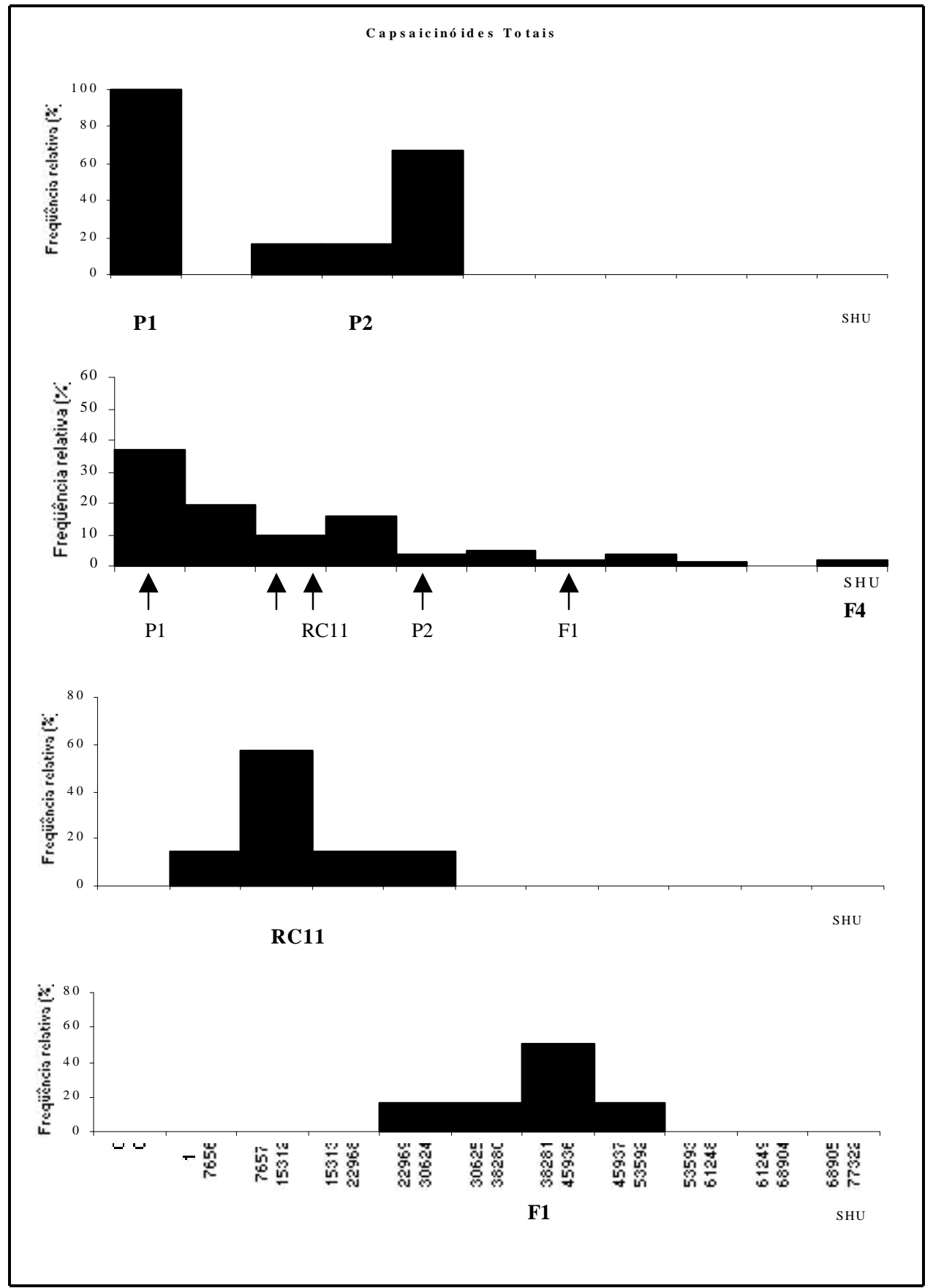

Figura 6 - Histograma de distribuição de frequiência das análises de capsaicinóides totais, em unidade Scoville de calor (SHU) das gerações $\mathrm{P}_{1}, \mathrm{P}_{2}, \mathrm{~F}_{1}, \mathrm{RC}_{11}$ e $\mathrm{F}_{4}$, com as médias das gerações plotadas na base do gráfico da geração $F_{4}$. Capsicum аппиит L. 2002. 


\subsection{Análise de variância da pungência}

A análise de variância dos dados encontra-se na Tabela 4. Os coeficientes de variação foram altos: 79\%, 58\%, 73\% e 60\% para nordiidrocapsaicina, capsaicina, diidrocapsaicina e capsaicinóides totais, respectivamente. Porém os valores de F também foram altos e significativos ao nível de probabilidade de $1 \%$, sendo: $18,33,23$ e 30 para os efeitos de gerações e 10, 16, 10 e 14 para os efeitos de progênies $F_{4.3}$ em relação à nordiidrocapsaicina, capsaicina, diidrocapsaicina e capsaicinóides totais, respectivamente. $\mathrm{O}$ teste $\mathrm{F}$ para blocos foi não significativo para os três capsaicinóides e capsaicinóides totais. A significância destes valores $\mathrm{F}$ deve ser interpretada com certa cautela, tendo em vista a natureza dos dados. Pela amplitude de variação desses e pela presença de valores nulos, não se pode admitir a normalidade dos erros do modelo. Tentativas de transformação dos dados não surtiram efeito. Todavia pela magnitude dos valores $\mathrm{F}$ e considerando a robustez deste critério de teste, não parece haver dúvidas quanto à existência de variância genética entre as progênies. As estimativas da variância genética foram superiores às da variância residual. Os valores de herdabilidade, no sentido amplo, com base em média de parcela foram altos: $89 \%, 93 \%, 90 \%$ e $92 \%$ para nordiidrocapsaicina, capsaicina, diidrocapsaicina e capsaicinóides totais, respectivamente.

\subsection{Componentes de médias da pungência}

As médias de capsaicina foram superiores às de diidrocapsaicina e estas superiores à nordiidrocapsaicina (Tabela 5). As médias esperadas de $\mathrm{P}_{1}, \mathrm{~F}_{1}$ e $\mathrm{F}_{4}$ foram menores do que as observadas, exceção feita às médias da geração $F_{4}$ de nordiidrocapsaicina. Já as média esperadas de $\mathrm{P}_{2}$ e $\mathrm{RC}_{11}$ foram maiores que as médias observadas, para todos os capsaicinóides. O modelo genético aditivo-dominante, testado para os três parâmetros $\mathrm{m}$, somatório dos efeitos aditivos [a] e somatório dos efeitos dominantes [d] não foi adequado para explicar o comportamento das médias das gerações, admitindo-se a probabilidade de 5\%. Quando testado a $1 \%$ de probabilidade apenas o comportamento das médias de capsaicina puderam ser explicadas pelo modelo de três parâmetros. 
Tabela 4. Análise de variância de médias de parcela, com fontes de variação (FV), graus de liberdade (GL), quadrados médios (QM), teste F, média geral coeficiente de variação (C.V.), estimativas das variâncias genética e residual e herdabilidade no sentido amplo, de nordiidrocapsaicina (Nordiidro), capsaicina, diidrocapsaicina (Diidro) e capsaicinóides totais (Caps. Totais). Capsicum annuum L. 2002.

\begin{tabular}{|c|c|c|c|c|c|c|c|c|c|}
\hline \multirow{2}{*}{$\mathrm{FV}$} & \multirow{2}{*}{ GL } & \multicolumn{2}{|c|}{ Nordiidro } & \multicolumn{2}{|c|}{ Capsaicina } & \multicolumn{2}{|l|}{ Diidro } & \multicolumn{2}{|c|}{ Caps. Totais } \\
\hline & & $\mathrm{QM}$ & $\mathrm{F}$ & $\mathrm{QM}$ & $\mathrm{F}$ & QM & $\mathrm{F}$ & $\mathrm{QM}$ & $\mathrm{F}$ \\
\hline Blocos & 2 & 395845 & $3^{\text {ns }}$ & 49304378 & $3^{\text {ns }}$ & 30801012 & $3^{\text {ns }}$ & 71605278 & $1,3^{\text {ns }}$ \\
\hline Gerações & 4 & 2230030 & $18^{* *}$ & 586531572 & $33^{* *}$ & 255973931 & $23^{* *}$ & 1699875038 & $30^{* *}$ \\
\hline Progênies $F_{4}$ & 101 & 1212141 & $9^{* *}$ & 285496728 & $15^{* *}$ & 114622386 & $10^{* *}$ & 802935623 & $13^{* *}$ \\
\hline Resíduo & 209 & 124749 & & 17955450 & & 11244151 & & 55539781 & \\
\hline Total & 316 & & & & & & & & \\
\hline Resíduo $\mathrm{F}_{4}$ & 185 & 132599 & & 19241586 & & 11805966 & & 60290205 & \\
\hline Média & & 44 & & 732 & & 461 & & 1238 & \\
\hline C.V. & & $79 \%$ & & $58 \%$ & & $73 c$ & & $60 \%$ & \\
\hline$\sigma_{p}^{2}$ & & 35984 & & 8875171 & & 3427214 & & 24754847 & \\
\hline$\sigma^{2^{p}}$ & & 13259 & & 1924158 & & 1180596 & & 6029020 & \\
\hline $\mathrm{h}_{\mathrm{m}}^{2}$ & & $89 \%$ & & $93 \%$ & & $90^{\circ}$ & & $92 \%$ & \\
\hline
\end{tabular}

Os valores calculados de qui-quadrado foram de 23,$4 ; 6,1 ; 10,7$ e 14,6 para nordiidrocapsaicina, capsaicina, diidrocapsaicina e capsaicinóides totais, respectivamente. Os valores tabelados de qui-quadrado são: $\chi_{(2 \text { G.L; } \alpha=0,05)}^{2}=5,99$ e $\chi_{(2}^{2}$ G.L; $\alpha=0,01)=9,21$, para este caso.

Foi incluído no modelo o somatório dos efeitos epistáticos [i] do tipo aditivo $\mathrm{x}$ aditivo (Tabela 6). Conforme verificado nas Figuras 3 a 6 as médias de $\mathrm{RC}_{11}$ são influenciadas, provavelmente por [i], no sentido do alelo favorável. Assim, os valores de [i] foram estimados considerando que os genes epistáticos estão em associação. No caso de estarem em repulsão a estimativa de [i] atuará nas médias no sentido do alelo desfavorável e o sinal será negativo.

O modelo genético com os quatro parâmetros explicou o comportamento das médias das gerações sendo que os valores de qui-quadrado foram não significativos em 
todos os capsaicinóides (Tabela 6). O modelo foi testado contra os valores tabelados $\chi_{(1 \mathrm{G} . L ; \alpha=0,05)}^{2}=3,84$ e $\chi^{2}(1$ G.L; $\alpha=0,01)=6,64$.

Desenvolvendo o teste de escala conjunta foram obtidas as estimativas dos quatro parâmetros a saber: m, somatório dos efeitos aditivos [a], somatório dos efeitos dominantes [d] e somatório dos efeitos epistáticos [i] do tipo aditivo x aditivo. As estimativas de [d] apresentaram magnitudes de, aproximadamente, o dobro das estimativas de [a] na capsaicina, diidrocapsaicina e capsaicinóides totais. A exceção foi a nordiidrocapsaicina, que apresentou estimativas de [a] semelhantes às de [d]. Os valores das estimativas de [i] foram inferiores aos dos demais parâmetros em todos os capsaicinóides.

Tabela 5. Médias observadas e esperadas de nordiidrocapsaicina (nordiidro), capsaicina, diidrocapsaicina (diidro) e capsaicinóides totais (Capsc. Totais), nas cinco gerações, obtidos da análise de componentes de médias para quatro parâmetros com os respectivos valores do teste de qui-quadrado. Capsicum annuum L. 2002.

\begin{tabular}{|c|c|c|c|c|c|c|c|c|}
\hline \multirow[b]{2}{*}{ Gerações } & \multicolumn{2}{|c|}{ Nordiidro } & \multicolumn{2}{|c|}{ Capsaicina } & \multicolumn{2}{|c|}{ Diidrocapsaicina } & \multicolumn{2}{|c|}{ Caps. Totais } \\
\hline & $\begin{array}{l}\text { Média } \\
\text { obs. }\end{array}$ & $\begin{array}{l}\text { Média } \\
\text { esp. }\end{array}$ & $\begin{array}{l}\text { Média } \\
\text { obs. }\end{array}$ & $\begin{array}{l}\text { Média } \\
\text { esp. }\end{array}$ & $\begin{array}{l}\text { Média } \\
\text { obs. }\end{array}$ & $\begin{array}{l}\text { Média } \\
\text { esp. }\end{array}$ & $\begin{array}{l}\text { Média } \\
\text { obs. }\end{array}$ & $\begin{array}{l}\text { Média } \\
\text { esp. }\end{array}$ \\
\hline $\mathrm{P}_{1}$ & 0 & -4 & 0 & -342 & 0 & -308 & 0 & -400 \\
\hline $\mathrm{RC}_{11}$ & 383 & 408 & 8724 & 11234 & 4792 & 6402 & 13899 & 18374 \\
\hline $\mathrm{F}_{1}$ & 997 & 990 & 24188 & 23552 & 14808 & 14236 & 39994 & 39251 \\
\hline $\mathrm{F}_{4}$ & 433 & 433 & 7062 & 7043 & 4418 & 4406 & 11912 & 11878 \\
\hline $\mathrm{P}_{2}$ & 1392 & 1394 & 12506 & 12677 & 10654 & 10808 & 24552 & 24752 \\
\hline $\mathrm{m}$ & & & 468 & & 30 & & & \\
\hline [a] & & & 65 & & 55 & & & \\
\hline [d] & & & 188 & & 112 & & & \\
\hline [i] & & & $14 \varepsilon$ & & 22 & & & \\
\hline$\chi^{2}$ & 0.0 & & 2.90 & & 2.02 & & & \\
\hline
\end{tabular}

Os valores obtidos de $\chi^{2}$ foram significativos quando testada a hipótese de segregação genética de um gene dominante em todos os capsaicinóides (proporção 3:1). Já para a presença de interação não alélica o teste foi não significativo (proporção 9:7 -Tabela 6). 
Na Tabela 7 são apresentadas as médias de progênies $\mathrm{F}_{4.3}$ nos três blocos. Foram identificados, 64 pungentes e 38 progênies doces. Dos pungentes, seis (769, 787, 790, 811, 862 e 879) não apresentaram nordiidrocapsaicina e um (795) apresentou apenas nordiidrocapsaicina. O genótipo 862 só apresentou capsaicina e o 769 só apresentou diidrocapsaicina. Ao observar os dados originais (Anexo B) verifica-se que sete progênies $(787,790,795,803,811,826$ e 862) foram doces em alguma repetição e pungente em outras, nos capsaicinóides estudados. Ainda nos dados originais verifica-se que para a ocorrência de apenas um capsaicinóide doce em alguma repetição e pungente nas demais existem nove progênies $(785,790,811,826,830,836,839,845$ e 847).

Tabela 6. Capsaicinóides. Hipótese de segregação fenotípica, frequiências observadas e esperadas de progênies doces e pungentes e teste do qui-quadrado* . Capsicum annuum L. 2002.

\begin{tabular}{|c|c|c|c|c|c|}
\hline \multirow{2}{*}{ Capsaicinóides } & \multicolumn{3}{|c|}{ Freqüência observada } & Freqüência esperada & \multirow{2}{*}{$\chi^{2}$} \\
\hline & Hipótese & pungente & Doce & pungente & \\
\hline Nordiidrocapsaicina & & 58 & 44 & \multirow{4}{*}{$77: 26$} & $17,9^{*}$ \\
\hline Capsaicina & & 32 & 40 & & $10,9^{*}$ \\
\hline Diidrocapsaicina & $3: 1$ & 62 & 40 & & $10,9^{*}$ \\
\hline Capsaicinóides totais & & 64 & 38 & & $8,2^{*}$ \\
\hline Nordiidrocapsaicina & \multirow{4}{*}{$9: 7$} & 58 & 44 & \multirow{4}{*}{$57: 45$} & $0,02^{\mathrm{ns}}$ \\
\hline Capsaicina & & 32 & 40 & & $0,8^{\mathrm{ns}}$ \\
\hline Diidrocapsaicina & & 62 & 40 & & $0,8^{\mathrm{ns}}$ \\
\hline Capsaicinóides totais & & 64 & 38 & & $1,7^{\mathrm{ns}}$ \\
\hline
\end{tabular}

$* \chi_{(1 \text { G.L; } \alpha=0,05)}^{2}=3,84$

Foram verificados seis progênies $(782,795,846,862,876$ e 879) que apresentaram dois capsaicinóides doces em alguma repetição e pungente nas demais. 
Tabela 7. Número de observações (n) e médias das progênies $\mathrm{F}_{4.3}$, nos três blocos para nordiidrocapsaicina (nordiidro), capsaicina, diidrocapsaicina (diidro) e capsaicinóides totais (Caps. Totais). Capsicum annuum L. 2002.

\begin{tabular}{|c|c|c|c|c|c|}
\hline Progênies $\mathrm{F}_{4.3}$ & $\mathrm{n}$ & Nordiidro & Capsaicina & Diidro & Caps. Totais \\
\hline 766 & 3 & 751 & 12330 & 9978 & 23060 \\
\hline 769 & 2 & 0 & 0 & 110 & 110 \\
\hline 771 & 2 & 1164 & 11753 & 8290 & 21207 \\
\hline 773 & 2 & 1215 & 14115 & 13933 & 29264 \\
\hline 774 & 2 & 347 & 110198 & 4115 & 14659 \\
\hline 775 & 3 & 1689 & 17765 & 10916 & 30369 \\
\hline 776 & 3 & 1542 & 19755 & 14361 & 35658 \\
\hline 777 & 3 & 3414 & 48969 & 24939 & 77322 \\
\hline 779 & 3 & 0 & 0 & 0 & 0 \\
\hline 780 & 3 & 502 & 7317 & 4620 & 12439 \\
\hline 781 & 3 & 0 & 0 & 0 & 0 \\
\hline 782 & 3 & 277 & 616 & 219 & 1112 \\
\hline 783 & 3 & 447 & 10436 & 4387 & 15271 \\
\hline 784 & 2 & 1508 & 29006 & 19011 & 49527 \\
\hline 785 & 3 & 139 & 1315 & 819 & 2274 \\
\hline 786 & 3 & 705 & 18943 & 9803 & 29451 \\
\hline 787 & 3 & 0 & 1017 & 275 & 1292 \\
\hline 789 & 3 & 0 & 0 & 0 & 0 \\
\hline 790 & 3 & 0 & 52 & 95 & 147 \\
\hline 791 & 3 & 45 & 877 & 334 & 1256 \\
\hline 792 & 3 & 0 & 0 & 0 & 0 \\
\hline 795 & 3 & 119 & 0 & 0 & 119 \\
\hline 796 & 3 & 429 & 9028 & 5212 & 14669 \\
\hline 797 & 3 & 0 & 0 & 0 & 0 \\
\hline 799 & 3 & 0 & 0 & 0 & 0 \\
\hline 800 & 3 & 1831 & 25292 & 14838 & 41960 \\
\hline 802 & 3 & 645 & 12487 & 7071 & 20203 \\
\hline 803 & 3 & 71 & 1561 & 602 & 2234 \\
\hline 804 & 3 & 441 & 5989 & 3462 & 9892 \\
\hline 806 & 3 & 0 & 0 & 0 & 0 \\
\hline 807 & 3 & 324 & 11245 & 4964 & 16534 \\
\hline 808 & 3 & 0 & 0 & 0 & 0 \\
\hline 809 & 3 & 0 & 0 & 0 & 0 \\
\hline 810 & 3 & 658 & 18567 & 11651 & 30875 \\
\hline 811 & 3 & 0 & 107 & 217 & 324 \\
\hline 813 & 2 & 1329 & 45778 & 26319 & 73426 \\
\hline 817 & 2 & 0 & 0 & 0 & 0 \\
\hline 819 & 3 & 286 & 8653 & 3592 & 12532 \\
\hline
\end{tabular}


Tabela 7. Número de observações (n) e médias das progênies $F_{4}$, nos três blocos para nordiidrocapsaicina (nordiidro), capsaicina, diidrocapsaicina (diidro) e capsaicinóides totais (Caps. Totais). Capsicum annuum L. 2002.

\begin{tabular}{|c|c|c|c|c|c|}
\hline Progênies $\mathrm{F}_{4.3}$ & $\mathrm{n}$ & Nordiidro & Capsaicina & Diidro & Caps. Totais \\
\hline 821 & 3 & 672 & 12313 & 8814 & 21799 \\
\hline 822 & 2 & 185 & 4482 & 2325 & 6993 \\
\hline 823 & 3 & 0 & 0 & 0 & 0 \\
\hline 824 & 2 & 952 & 12113 & 7761 & 20826 \\
\hline 825 & 3 & 0 & 0 & 0 & 0 \\
\hline 826 & 3 & 86 & 2504 & 1335 & 3925 \\
\hline 827 & 3 & 0 & 0 & 0 & 0 \\
\hline 828 & 2 & 0 & 0 & 0 & 0 \\
\hline 829 & 3 & 0 & 0 & 0 & 0 \\
\hline 830 & 3 & 661 & 6231 & 2132 & 9023 \\
\hline 831 & 3 & 696 & 11385 & 7336 & 19418 \\
\hline 832 & 3 & 784 & 9793 & 8667 & 19245 \\
\hline 833 & 2 & 1352 & 7663 & 8787 & 17804 \\
\hline 835 & 3 & 943 & 22425 & 14058 & 37426 \\
\hline 836 & 3 & 37 & 1143 & 1450 & 2630 \\
\hline 839 & 3 & 34 & 1914 & 893 & 2841 \\
\hline 840 & 3 & 0 & 0 & 0 & 0 \\
\hline 842 & 3 & 0 & 0 & 0 & 0 \\
\hline 843 & 3 & 1292 & 17919 & 13083 & 32294 \\
\hline 844 & 3 & 379 & 15041 & 4226 & 19646 \\
\hline 845 & 3 & 112 & 3633 & 1574 & 5319 \\
\hline 846 & 3 & 52 & 1292 & 672 & 2017 \\
\hline 847 & 3 & 112 & 1743 & 707 & 2562 \\
\hline 848 & 3 & 0 & 0 & 0 & 0 \\
\hline 849 & 3 & 286 & 5486 & 2272 & 8044 \\
\hline 850 & 3 & 655 & 13129 & 6016 & 19800 \\
\hline 851 & 3 & 0 & 0 & 0 & 0 \\
\hline 852 & 3 & 826 & 21528 & 10219 & 32573 \\
\hline 853 & 3 & 0 & 0 & 0 & 0 \\
\hline 855 & 3 & 0 & 0 & 0 & 0 \\
\hline 856 & 2 & 0 & 0 & 0 & 0 \\
\hline 857 & 3 & 0 & 0 & 0 & 0 \\
\hline 858 & 3 & 64 & 920 & 758 & 1741 \\
\hline 859 & 3 & 0 & 0 & 0 & 0 \\
\hline 862 & 3 & 0 & 898 & 0 & 898 \\
\hline 863 & 3 & 507 & 10660 & 7526 & 18694 \\
\hline 864 & 3 & 0 & 0 & 0 & 0 \\
\hline 865 & 3 & 1417 & 29719 & 15198 & 46334 \\
\hline 866 & 3 & 0 & 0 & 0 & 0 \\
\hline
\end{tabular}


Tabela 7. Número de observações (n) e médias das progênies $F_{4}$, nos três blocos para nordiidrocapsaicina (nordiidro), capsaicina, diidrocapsaicina (diidro) e capsaicinóides totais (Caps. Totais). Capsicum annuum L. 2002.

\begin{tabular}{|c|c|c|c|c|c|}
\hline Progênies $\mathrm{F}_{4.3}$ & $\mathrm{n}$ & Nordiidro & Capsaicina & Diidro & Caps. Totais \\
\hline 867 & 3 & 2897 & 23493 & 25612 & 52003 \\
\hline 868 & 3 & 1860 & 32910 & 22052 & 56823 \\
\hline 869 & 2 & 1127 & 9381 & 10384 & 20893 \\
\hline 870 & 3 & 0 & 0 & 0 & 0 \\
\hline 871 & 3 & 826 & 10359 & 9589 & 20774 \\
\hline 872 & 2 & 967 & 11395 & 8726 & 21088 \\
\hline 873 & 3 & 0 & 0 & 0 & 0 \\
\hline 874 & 3 & 1603 & 30057 & 16769 & 48429 \\
\hline 875 & 3 & 0 & 0 & 0 & 0 \\
\hline 876 & 3 & 41 & 2938 & 954 & 3933 \\
\hline 877 & 3 & 316 & 11046 & 6032 & 17394 \\
\hline 878 & 3 & 0 & 0 & 0 & 0 \\
\hline 879 & 2 & 0 & 2211 & 660 & 2871 \\
\hline 880 & 3 & 0 & 0 & 0 & 0 \\
\hline 881 & 3 & 0 & 0 & 0 & 0 \\
\hline 882 & 3 & 0 & 0 & 0 & 0 \\
\hline 884 & 2 & 0 & 0 & 0 & 0 \\
\hline 885 & 3 & 514 & 7511 & 5247 & 13272 \\
\hline 886 & 3 & 0 & 0 & 0 & 0 \\
\hline 887 & 2 & 1752 & 23615 & 17993 & 43360 \\
\hline 888 & 3 & 0 & 0 & 0 & 0 \\
\hline 889 & 3 & 0 & 0 & 0 & 0 \\
\hline 890 & 3 & 898 & 5181 & 5590 & 11669 \\
\hline 891 & 3 & 534 & 9847 & 5952 & 16333 \\
\hline 892 & 3 & 0 & 0 & 0 & 0 \\
\hline $\mathrm{s}(\overline{\mathrm{Y}})_{\mathrm{F} 4}=$ & & 210 & 2533 & 1984 & 4483 \\
\hline $\mathrm{s}(\overline{\mathrm{Y}})_{\mathrm{P} 1, \mathrm{P} 2 \mathrm{e} \text { F1 }}=$ & & 143 & 1673 & 1567 & 2381 \\
\hline $\mathrm{s}(\overline{\mathrm{Y}})_{\mathrm{RC} 11}=$ & & 204 & 2446 & 1936 & 4303 \\
\hline
\end{tabular}

Conforme verificado na Tabela 8 , as médias gerais da população $\mathrm{F}_{4}$ foram 433, 7062, 4418 e 11912 para nordiidrocapsaicina, capsaicina, diidrocapsaicina e capsaicinóides totais, respectivamente.

No caso de uma seleção para aumento da pungência, como normalmente ocorre, o progresso esperado aumentou com a intensidade de seleção (5\%, 10\% e 20\%). Isso, no 
entanto, não ocorreu quando se simulou uma seleção para redução da pungência (Tabela 8).

O progresso genético para aumentar a pungência, em progênies $F_{4.3}$ derivadas de $F_{2}$ via SSD, foi superior ao esperado numa seleção para diminuí-la. Considerando a pressão de seleção de 5 \%, obteve-se um progresso esperado de 1707 SHU, 28295 SHU, 17060 SHU e 46415 SHU, para nordiidrocapsaicina, capsaicina, diidrocapsaicina e capsaicinóides totais, respectivamente; enquanto o progresso para diminuir a pungência foi de -385 SHU, -6568 SHU, -3932 SHU e -11078 SHU, respectivamente. O mesmo padrão de comportamento foi verificado nos ganhos genéticos com seleção negativa quando a população foi submetida a pressões de seleção de $10 \%$ e $20 \%$.

\subsection{Análise de correlação}

Os resultados da análise de correlação entre as avaliações obtidas via análise sensorial dos frutos e do extrato etanólico com a variável capsaicinóides totais estão na Tabela 9. As correlações entre as avaliações do fruto $(0,63)$ e do extrato etanólico $(0,62)$ com os resultados de capsaicinóides totais foram semelhantes. A maior correlação foi detectada entre as avaliações sensoriais do fruto contra o extrato etanólico $(0,92)$. A metodologia de quantificação dos capsaicinóides totais por cromatografia (CLAE) foi 37\% mais eficiente em relação à avaliação sensorial do fruto e 38\% mais eficiente em relação a avaliação sensorial do extrato etanólico. Todos os coeficientes foram significativos à probabilidade de 0,0001 .

Tabela 9. Resultado da análise de correlação simples de Pearson entre as avaliações sensoriais do fruto e do extrato etanólico com capsaicinóides totais, quantificado por CLAE. Progênies F 4.3 . Capsicum annuum L. 2002.

\begin{tabular}{lccc}
\hline & Fruto & Extrato etanólico & Capsaicinóide totais \\
\hline Fruto & 1 & 0,92 & 0,63 \\
Extrato etanólico & & 1 & 0,62 \\
Capsaicinóide totais & & & 1 \\
\hline
\end{tabular}


Tabela 8 - Médias das progênies selecionadas $\left(\overline{\mathrm{Y}}_{\mathrm{s}}\right)$, da população original $\left(\overline{\mathrm{Y}}_{\mathrm{o}}\right)$ e ganho genético com seleção (Gs) para aumentar e diminuir a pungênia, sob diferentes pressões de seleção $(5 \%, 10 \%$ e $20 \%)$ para nordiidrocapsaicina capsaicina, diidrocapsaicina e capsaicinóides totais. Capsicum аппиит L. 2002.

\begin{tabular}{|c|c|c|c|c|c|c|c|}
\hline \multirow{2}{*}{ Capsaicinóide } & \multicolumn{3}{|c|}{$5 \%$} & \multicolumn{2}{|l|}{$10 \%$} & \multicolumn{2}{|c|}{$20 \%$} \\
\hline & $\overline{\mathrm{Y}}_{\mathrm{o}}$ & $\overline{\mathrm{Y}}_{\mathrm{s}}$ & Gs & $\overline{\mathrm{Y}}_{\mathrm{s}}$ & Gs & $\overline{\mathrm{Y}}_{\mathrm{s}}$ & Gs \\
\hline \multicolumn{8}{|c|}{$\overline{\text { Seleção para aumentar a pungência }}$} \\
\hline Nordidro & 433 & 2351 & 1707 & 1951 & 1351 & 1538 & 983 \\
\hline Capsaicina & 7062 & 37487 & 28295 & 31126 & 22380 & 24026 & 15776 \\
\hline Diidro & 4418 & 23587 & 17060 & 19709 & 13609 & 15535 & 9895 \\
\hline Caps. Totais & 11912 & 61820 & 46415 & 52661 & 37897 & 40658 & 26734 \\
\hline \multicolumn{8}{|c|}{ Seleção para diminuir a pungência } \\
\hline Nordidro & 443 & 0 & -385 & 0 & -385 & 0 & -385 \\
\hline Capsaicina & 7062 & 0 & -6568 & 0 & -6568 & 0 & -6568 \\
\hline Diidro & 4418 & 0 & -3932 & 0 & -3932 & 0 & -3932 \\
\hline Caps. Totais & 11912 & 0 & -11078 & 0 & -11078 & 0 & -11078 \\
\hline
\end{tabular}




\subsection{Histograma de distribuição de freqüência dos dados de produtividade e demais caracteres do fruto}

Os genitores foram contrastantes quanto a resposta à produtividade, peso médio do fruto, largura e comprimento do fruto. Na espessura da polpa houve sobreposição de classes para os genitores e em número de frutos $\mathrm{P}_{1}$ e $\mathrm{P}_{2}$ foram pouco divergentes sem no entanto, ocorrer sobreposição de classes para este caráter (Figuras 7 a 12).

Foi verificada a ocorrência de segregação transgressiva no sentido do genitor $\mathrm{P}_{1} \mathrm{em}$ todos caracteres avaliados, sendo que em peso médio do fruto (Figura 12) foi no sentido dos dois genitores.

As médias das avaliações da geração $\mathrm{F}_{1}$ quanto à produtividade, peso médio do fruto e largura do fruto ficaram compreendidas entre as médias dos genitores (Figuras 10, 12 e 7). Já quando avaliados o comprimento e o número de frutos na $F_{1}$, alguns genótipos apresentaram valores superiores ao do genitor $\mathrm{P}_{1}$, genitor de maior comprimento (Figuras 11 e 8). As médias das avaliações da geração $\mathrm{RC}_{11}$ ficaram compreendidas entre a amplitude de variação dos genitores e mais próximo do genitor recorrente $\left(\mathrm{P}_{1}\right)$ em largura e comprimento do fruto (Figuras 7 e 8 ), sendo que no caso da espessura da polpa houve sobreposição de classes entre $\mathrm{P}_{1}, \mathrm{P}_{2}$ e $\mathrm{RC}_{11}$ (Figura 9). 


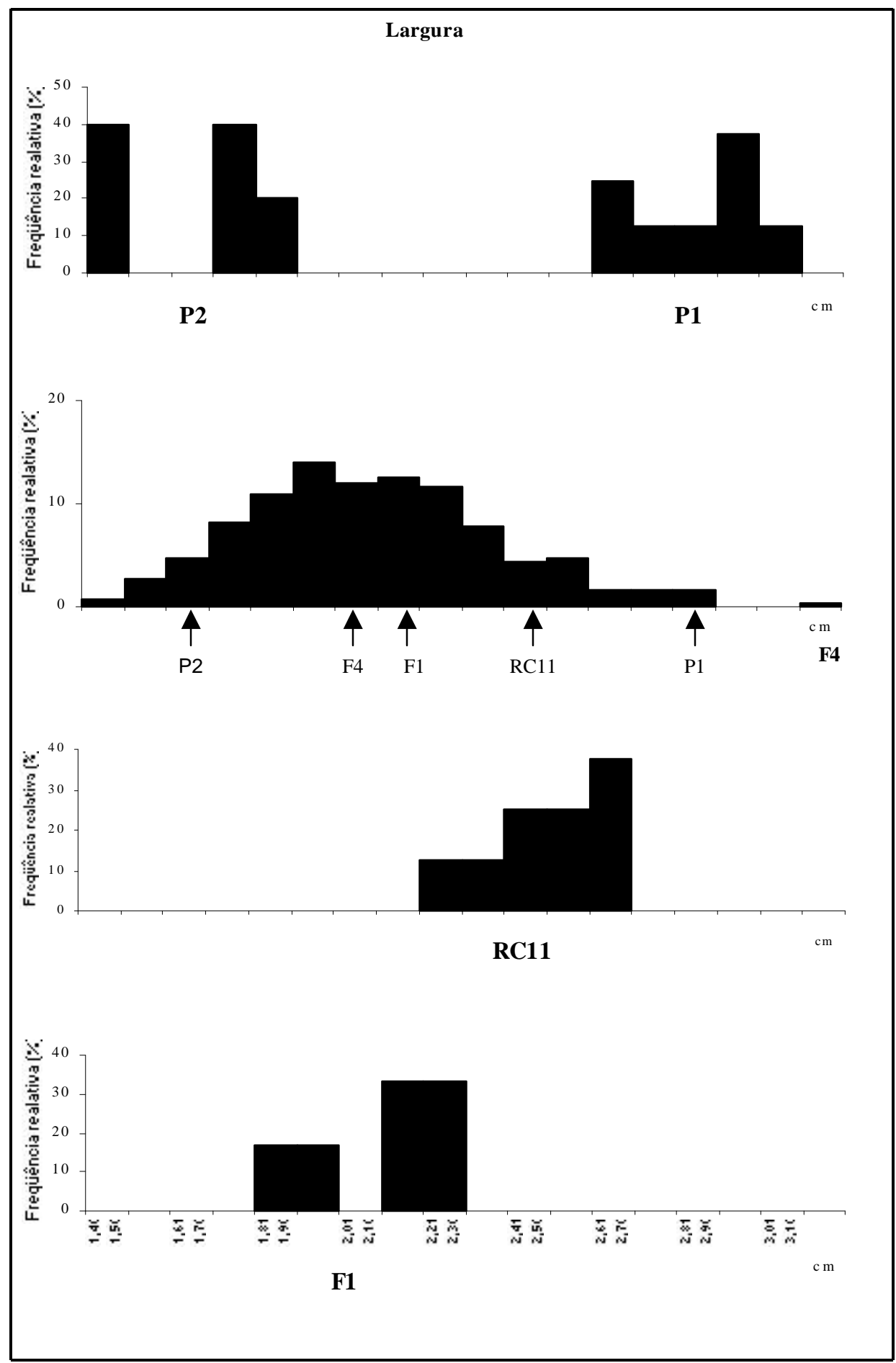

Figura 7 - Histograma de distribuição de freqüência dos dados de largura do fruto em $\mathrm{cm}$ das gerações $\mathrm{P}_{1}, \mathrm{P}_{2}, \mathrm{~F}_{1}, \mathrm{RC}_{11}$ e $\mathrm{F}_{4}$, com as médias das gerações plotadas na base do gráfico da geração $\mathrm{F}_{4}$. Capsicum annuum L. 2002 . 


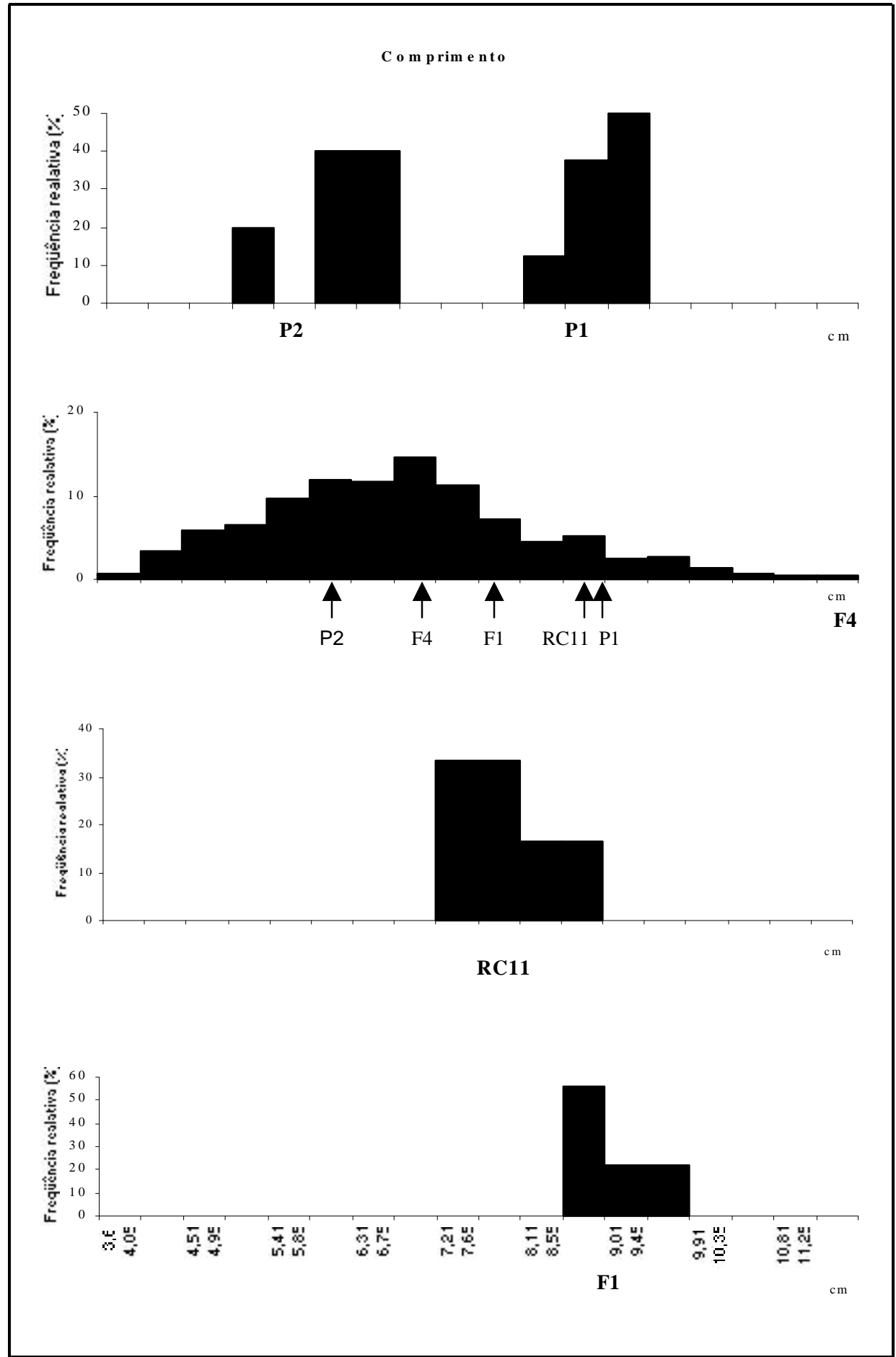

Figura 8 - Histograma de distribuição de freqüência dos dados de comprimento do fruto em $\mathrm{cm}$ das gerações $\mathrm{P}_{1}, \mathrm{P}_{2}, \mathrm{~F}_{1}, \mathrm{RC}_{11}$ e $\mathrm{F}_{4}$, com as médias das gerações plotadas na base do gráfico da geração $\mathrm{F}_{4}$. Capsicum annuum L. 2002. 


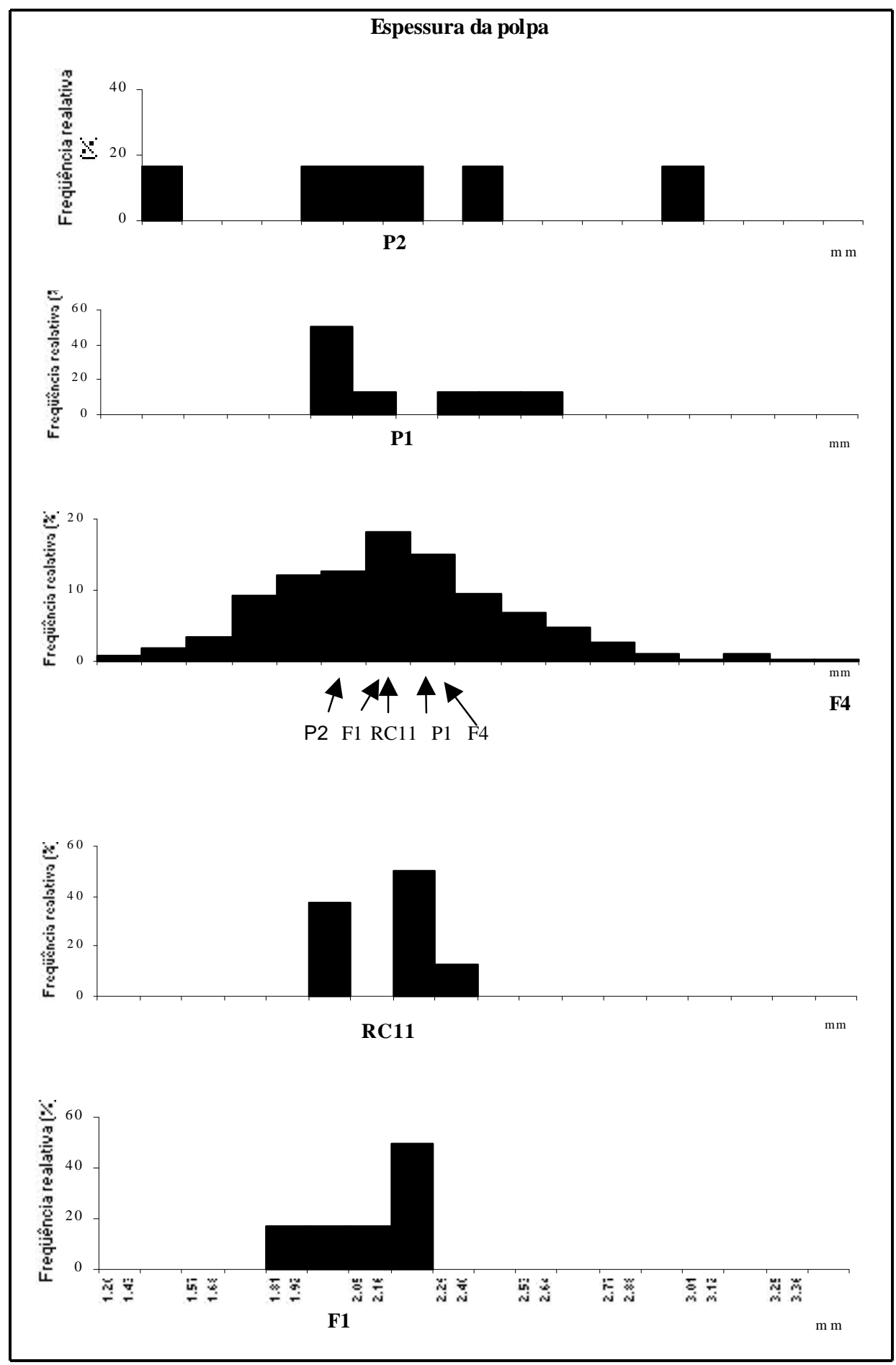

Figura 9 - Histograma de distribuição de freqüência dos dados de espessura da polpa em $\mathrm{mm}$ das gerações $\mathrm{P}_{1}, \mathrm{P}_{2}, \mathrm{~F}_{1}, \mathrm{RC}_{11}$ e $\mathrm{F}_{4}$, com as médias das gerações plotadas na base do gráfico da geração $\mathrm{F}_{4}$. Capsicum annuum L. 2002. 


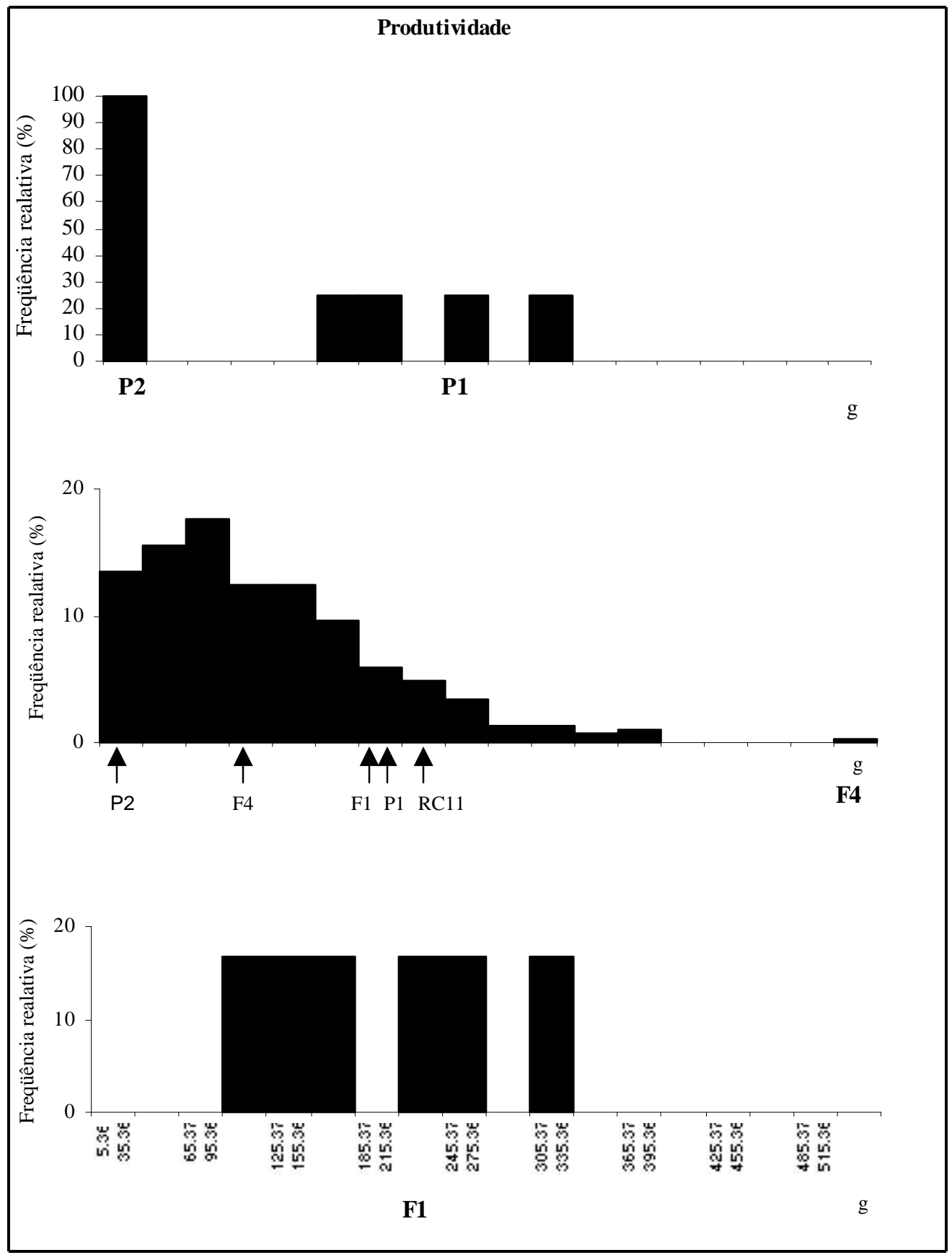

Figura 10 - Histograma de distribuição de freqüência dos dados de produtividade de frutos em gramas das gerações $\mathrm{P}_{1}, \mathrm{P}_{2}, \mathrm{~F}_{1}, \mathrm{RC}_{11}$ e $\mathrm{F}_{4}$, com as médias das gerações plotadas na base do gráfico da geração $\mathrm{F}_{4}$. Capsicum annuum L. 2002. 


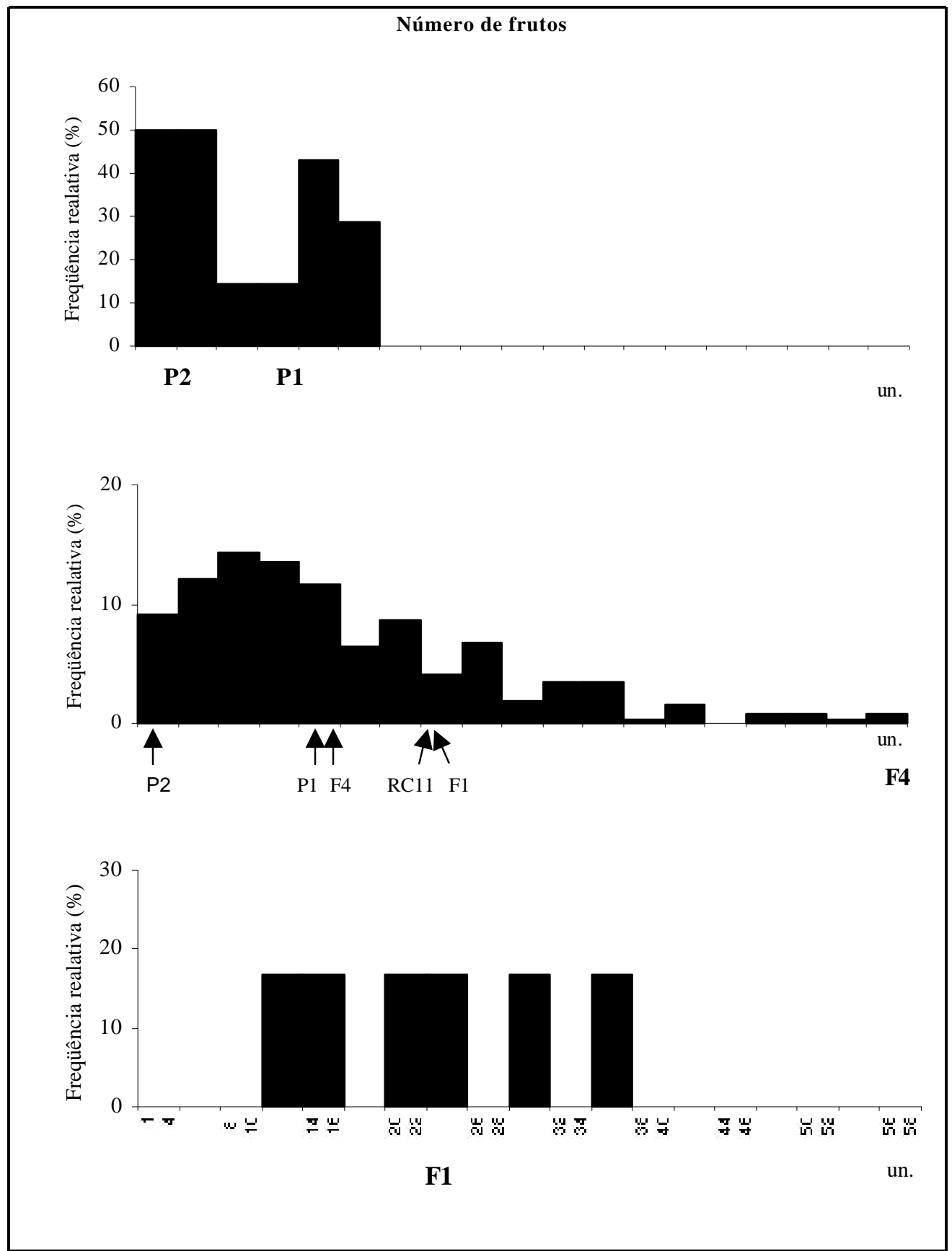

Figura 11 - Histograma de distribuição de frequiência dos dados de número de frutos das gerações $\mathrm{P}_{1}, \mathrm{P}_{2}, \mathrm{~F}_{1}, \mathrm{RC}_{11}$ e $\mathrm{F}_{4}$, com as médias das gerações plotadas na base do gráfico da geração $\mathrm{F}_{4}$. Capsicum anпиит L. 2002. 


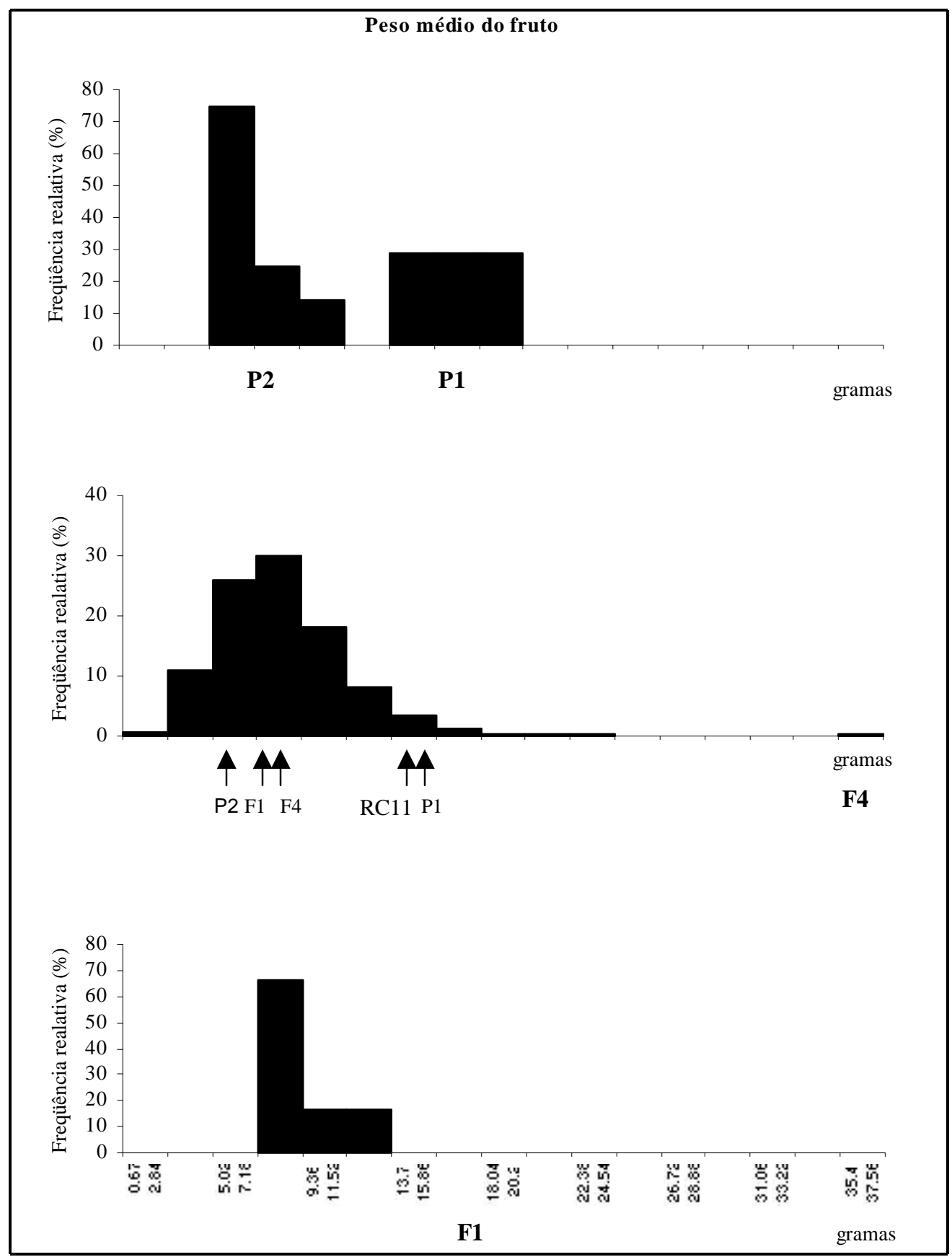

Figura 12 - Histograma de distribuição de freqüência dos dados do peso médio dos frutos em gramas das gerações $\mathrm{P}_{1}, \mathrm{P}_{2}, \mathrm{~F}_{1}, \mathrm{RC}_{11} \mathrm{e} \mathrm{F}_{4}$, com as médias das gerações plotadas na base do gráfico da geração $\mathrm{F}_{4}$. Capsicum annuum L. 2002. 


\subsection{Análise de variância da produtividade e demais caracteres do fruto}

Os resultados da análise de variância de largura e comprimento do fruto e espessura da polpa estão na Tabela 10 e os de produtividade, número de frutos e peso médio do fruto na Tabela 11. Os coeficientes de variação dos dados analisados na Tabela 10 foram baixos, sendo de $7 \%$ na largura do fruto e $9 \%$ no comprimento do fruto e espessura da polpa. Os testes de $\mathrm{F}$ foram significativos para blocos, gerações e progênies de todos os caracteres avaliados. Exceção feita para gerações na espessura da polpa que foi não significativo.

As variâncias de progênies foram maiores que as variâncias residuais em todos os caracteres avaliados. As herdabilidades de médias de parcela, no sentido amplo foram de 90\%, 92\% e 80\% para largura e comprimento do fruto e espessura da polpa, respectivamente (Tabela 10$)$.

Tabela 10. Análise de variância de médias de parcela, com fontes de variação (FV), graus de liberdade (GL), quadrados médios (QM), teste F, média geral, coeficiente de variação (C.V.), estimativas das variâncias genética e residual e herdabilidade no sentido amplo, de largura e comprimento do fruto e espessura da polpa. Capsicum annuum L. 2002.

\begin{tabular}{|c|c|c|c|c|c|c|c|c|}
\hline \multirow{2}{*}{$\mathrm{FV}$} & \multirow{2}{*}{ GL } & \multicolumn{2}{|c|}{ Largura $(\mathrm{cm})$} & \multicolumn{2}{|c|}{ Comprimento $(\mathrm{cm})$} & \multicolumn{3}{|c|}{ Espessura (mm) } \\
\hline & & $\overline{\mathrm{QM}}$ & $\mathrm{F}$ & QM & $\mathrm{F}$ & GL & QM & $\mathrm{F}$ \\
\hline Blocos & 2 & 0,814 & $40^{* *}$ & 4,09 & $10^{* *}$ & 2 & 1,439 & $33^{* *}$ \\
\hline Gerações & 4 & 1,648 & $82^{* *}$ & 19,53 & $48^{* *}$ & 4 & 0,110 & $2,5^{\mathrm{ns}}$ \\
\hline Progênies $F_{4}$ & 101 & 0,215 & $11^{* *}$ & 5,28 & $13^{* *}$ & 101 & 0,198 & $4,5^{* *}$ \\
\hline Resíduo & 212 & 0,020 & & 0,410 & & 211 & 0,044 & \\
\hline Total & 319 & & & & & 318 & & \\
\hline Resíduo $\mathrm{F}_{4}$ & & 0,020 & & 0,424 & & & 0,040 & \\
\hline Média geral & & & & 6,94 & & & 2,24 & \\
\hline C.V. & & & & $9 \%$ & & & $9 \%$ & \\
\hline$\sigma_{p}^{2}$ & & & & 1,613 & & & 0,053 & \\
\hline$\sigma^{2}$ & & & & 0,42 & & & 0,040 & \\
\hline $\mathrm{h}_{\mathrm{m}}^{2}$ & & & & $92 \%$ & & & $80 \%$ & \\
\hline
\end{tabular}


Nos dados de produtividade, número de frutos e peso médio do fruto os coeficientes de variação foram altos ou seja, de $48 \%, 47 \%$ e $28 \%$ respectivamente. Porém os valores de $\mathrm{F}$ foram significativos em todas as fontes de variação testadas.

A variância residual foi maior que a genética e as herdabilidades no sentido amplo, calculadas com base em médias de parcela que foram $66 \%$ em produtividade e $71 \%$ em número de frutos e $69 \%$ em peso médio do fruto.

Tabela 11. Análise de variância de médias de parcela, com fontes de variação (FV), graus de liberdade (GL), quadrados médios (QM), teste F, média geral, coeficiente de variação (C.V.), estimativas das variâncias genética e residual e herdabilidade no sentido amplo, de produtividade, número de frutos e peso médio do fruto. Capsicum annuum L. 2002.

\begin{tabular}{|c|c|c|c|c|c|c|c|c|c|}
\hline \multirow{2}{*}{$\mathrm{FV}$} & \multirow{2}{*}{ GL } & \multicolumn{2}{|c|}{ Produtividade (g) } & \multirow{2}{*}{ GL } & \multicolumn{2}{|c|}{ Número de frutos } & \multicolumn{3}{|c|}{ Peso médio do fruto (g) } \\
\hline & & QM & $\mathrm{F}$ & & QM & $\mathrm{F}$ & GL & QM & $\mathrm{F}$ \\
\hline Blocos & 2 & 151043 & $42^{* *}$ & 2 & 1042 & $17^{* * *}$ & 2 & 149 & $24^{* *}$ \\
\hline Gerações & 4 & 60071 & $17^{* *}$ & 4 & 328 & $5^{* *}$ & 4 & 144 & $23^{* *}$ \\
\hline Progênies $F_{4}$ & 101 & 10128 & $3^{* *}$ & 101 & 206 & $3^{* *}$ & 101 & 20,42 & $3^{* *}$ \\
\hline Resíduo & 208 & 3622 & & 183 & 61,86 & & 180 & 6,32 & \\
\hline Total & 315 & & & 290 & & & 287 & & \\
\hline Resíduo $\mathrm{F}_{4}$ & 186 & 3444 & & & 59,25 & & & 6,23 & \\
\hline Média geral & & 126 & & & 17 & & & 8,85 & \\
\hline C.V. & & $48 \%$ & & & $47 \%$ & & & $28 \%$ & \\
\hline$\sigma_{p}^{2}$ & & 2228 & & & 48.92 & & & 4.73 & \\
\hline$\sigma^{2}$ & & 3444 & & & 59.25 & & & 6.23 & \\
\hline $\mathrm{h}_{\mathrm{m}}^{2}$ & & $66 \%$ & & & $71 \%$ & & & $69 \%$ & \\
\hline
\end{tabular}

\subsection{Componentes de média da produtividade e demais caracteres do fruto}

O modelo genético aditivo-dominante não foi suficiente para explicar o comportamento das médias das geração quanto a largura e comprimento do fruto, os valores de $\chi^{2}$ foram 17,7 e 97 , respectivamente, sendo significativos nos dois casos. Já a espessura da polpa apresentou $\chi^{2}$ de 4,06 , sendo não significativo a $5 \%$ de probabilidade. 
As estimativas dos efeitos de $\mathrm{m}$, [a] e [d] da espessura da polpa foram de 2,27 \pm 0,$02 ;-0,01 \pm 0,07$ e $-0,20 \pm 0,11$, respectivamente.

Os valores do cálculo do teste de escala conjunta para o modelo dos quatro parâmetros: m, [a], [d] e [i] dos caracteres mencionados acima, estão na Tabela 13. O comportamento das médias das gerações se adequaram ao modelo, sendo os valores de $\chi^{2}: 0,82 ; 0,02$ e 0,29 para largura e comprimento do fruto e espessura da polpa, respectivamente.

As estimativas de [a] foram positivas para todos os caracteres avaliados, podendo ser considerada nulas para espessura da polpa. As estimativas de [d] foram positivas na largura e comprimento do fruto e praticamente nula na largura do fruto. Já para espessura da polpa foi negativa. A estimativa de [i] foi positiva apenas em largura do fruto.

Tabela 12. Médias observadas e esperadas da largura e comprimento do fruto e espessura da polpa nas cinco gerações, obtidos da análise de componentes de médias com parâmetros e respectivos valores de qui-quadrado. Capsicum annuum L. 2002.

\begin{tabular}{|c|c|c|c|c|c|c|}
\hline \multirow{2}{*}{ Gerações } & \multicolumn{2}{|c|}{ Largura $(\mathrm{cm})$} & \multicolumn{2}{|c|}{ Comprimento $(\mathrm{cm})$} & \multicolumn{2}{|c|}{ Espessura (mm) } \\
\hline & Média obs. & Média esp. & Média obs. & Média esp. & Média obs. & Média esp \\
\hline $\mathrm{P}_{1}$ & 2,87 & 2,89 & 8,94 & 8,95 & 2,18 & 2,16 \\
\hline $\mathrm{RC}_{11}$ & 2,50 & 2,47 & 8,84 & 8,81 & 2,12 & 2,15 \\
\hline $\mathrm{F}_{1}$ & 2,11 & 2,14 & 8,00 & 8,01 & 2,09 & 2,06 \\
\hline $\mathrm{F}_{4}$ & 2,10 & 2,10 & 6,82 & 6,82 & 2,25 & 2,25 \\
\hline $\mathrm{P}_{2}$ & 1,68 & 1,67 & 1,68 & 1,68 & 2,07 & 2,08 \\
\hline $\mathrm{m}$ & \multicolumn{2}{|c|}{$2,09 \pm 0,01$} & \multicolumn{2}{|c|}{$6,65 \pm 0,05$} & \multicolumn{2}{|c|}{$2,28 \pm 0,02$} \\
\hline [a] & \multicolumn{2}{|c|}{$0,61 \pm 0,04$} & \multicolumn{2}{|c|}{$3,63 \pm 0,12$} & \multicolumn{2}{|c|}{$0,04 \pm 0,07$} \\
\hline [d] & \multicolumn{2}{|c|}{$0,04 \pm 0,06$} & \multicolumn{2}{|c|}{$1,36 \pm 0,20$} & \multicolumn{2}{|c|}{$-0,22 \pm 0,11$} \\
\hline [i] & \multicolumn{2}{|c|}{$0,18 \pm 0,04$} & \multicolumn{2}{|c|}{$-1,34 \pm 0,14$} & \multicolumn{2}{|c|}{$-0,16 \pm 0,08$} \\
\hline$x^{2}$ & \multicolumn{2}{|c|}{0,82} & \multicolumn{2}{|c|}{0,02} & \multicolumn{2}{|c|}{0,29} \\
\hline
\end{tabular}

Os valores de $\chi^{2}$ obtidos admitindo modelo genético aditivo-dominantes foram significativos em número de frutos $\left(\chi^{2}=16\right)$ e peso médio do fruto $\left(\chi^{2}=30\right)$. Já para a 
produtividade foi não significativo $\left(\chi^{2}=2,14\right)$. As estimativas da $\mathrm{m}$, [a] e [d] da produtividade, obtidas pelo teste de escala conjunta para tal modelo, foram de $107 \pm 5$, $104 \pm 14$ e $113 \pm 21$, respectivamente. Os valores do teste de $\chi^{2}$, bem como as estimativas dos parâmetros genéticos da produtividade, número de frutos e peso médio do fruto, do modelo incluindo epistasia, estão na Tabela 13.

Os valores obtidos de $\chi^{2}$ para a produtividade e número de frutos indicam que o modelo de quatro parâmetros é suficiente para explicar o comportamento das médias das gerações. Já no peso médio dos frutos as médias não se adequaram a tal modelo. As estimativas dos parâmetros genéticos da produtividade obtidas pelo modelo incluindo epistasia foram semelhantes às obtidas pelo modelo aditivo-dominante. A magnitude do efeito [i] tendeu a ser inferior aos demais efeitos. As estimativas dos efeitos m, [a], [d] e [i] quanto ao número de frutos foram de $15,6,8$ e -6 , respectivamente.

Não foram obtidas estimativas dos efeitos genéticos de peso médio dos frutos em função de nenhum dos modelos testados ter explicado o comportamento das médias das gerações.

Tabela 13. Médias observadas e esperadas de produtividade, número de frutos e peso médio do fruto nas cinco gerações, obtidos da análise de componentes de médias com quatro parâmetros e os respectivos valores de qui-quadrado. Capsicum annuum L. 2002.

\begin{tabular}{|c|c|c|c|c|c|c|}
\hline \multirow{2}{*}{ Gerações } & \multicolumn{2}{|c|}{ Produtividade (g) } & \multicolumn{2}{|c|}{ Número de frutos } & \multicolumn{2}{|c|}{ Peso médio do fruto $(\mathrm{g})$} \\
\hline & Média obs. & Média esp. & Média obs. & Média esp. & Média obs. & Média esp. \\
\hline $\mathrm{P}_{1}$ & 210 & 216 & 14 & 14 & 15,45 & 16,54 \\
\hline $\mathrm{RC}_{11}$ & 241 & 216 & 22 & 20 & 14,63 & 11,53 \\
\hline $\mathrm{F}_{1}$ & 211 & 221 & 23 & 23 & 6,30 & 7,87 \\
\hline $\mathrm{F}_{4}$ & 120 & 120 & 16 & 16 & 8,52 & 8,55 \\
\hline $\mathrm{P}_{2}$ & 19 & 15 & 3 & 3 & 6,76 & 6,12 \\
\hline $\mathrm{m}$ & \multicolumn{2}{|c|}{$106 \pm 5$} & \multicolumn{2}{|c|}{$15 \pm 0,61$} & \multicolumn{2}{|c|}{ - } \\
\hline [a] & \multicolumn{2}{|c|}{$101 \pm 15$} & \multicolumn{2}{|c|}{$6 \pm 1,49$} & \multicolumn{2}{|c|}{ - } \\
\hline [d] & \multicolumn{2}{|c|}{$116 \pm 22$} & \multicolumn{2}{|c|}{$8 \pm 2,24$} & \multicolumn{2}{|c|}{ - } \\
\hline [i] & \multicolumn{2}{|c|}{$10 \pm 16$} & \multicolumn{2}{|c|}{$-6 \pm 1,63$} & \multicolumn{2}{|c|}{ - } \\
\hline$x^{2}$ & \multicolumn{2}{|c|}{1,76} & \multicolumn{2}{|c|}{0,33} & \multicolumn{2}{|c|}{16,94} \\
\hline
\end{tabular}




\subsection{Resposta correlacionada à seleção para pungência, sobre a produtividade e demais caracteres do fruto}

Nas Tabelas 14 e 16 e ANEXO D estão as respostas correlacionadas da largura e comprimento do fruto, espessura da polpa, produtividade, número e peso médio de frutos para aumento da pungência, de uma população $F_{4}$ submetida às pressões de seleção de 5\%,10\% e 20\%. Observa-se que ao selecionar para aumento de pungência há uma tendência de decréscimo da largura, comprimento e produtividade, enquanto que para o número e peso médio de frutos ocorre aumento do caráter. A espessura da polpa permanece inalterada nas pressões de seleção de $10 \%$ e $20 \%$ e sofre uma tendência de decréscimo a 5\% de pressão de seleção para pungência.

As RCs dos caracteres do fruto para a diminuição da pungência estão nas Tabelas 15 e 17 e ANEXO E. Paralelamente ao decréscimo da pungência ocorreu também diminuição do comprimento e peso médio do fruto e acréscimo em largura, produtividade e número de frutos. De todos os caracteres avaliados quanto a RCs nos dois sentidos, a produtividade e o número de fruto apresentaram os maiores valores em relação aos demais caracteres. 
Tabela 14. Progresso direto (Gs) e resposta correlacionada (RCs) na largura e comprimento do fruto e espessura da polpa com seleção para aumento da pungência, sob diferentes pressões de seleção (\% sel. ) em progênies $F_{4.3}$ (Prog.). Capsicum annuиm L. 2002.

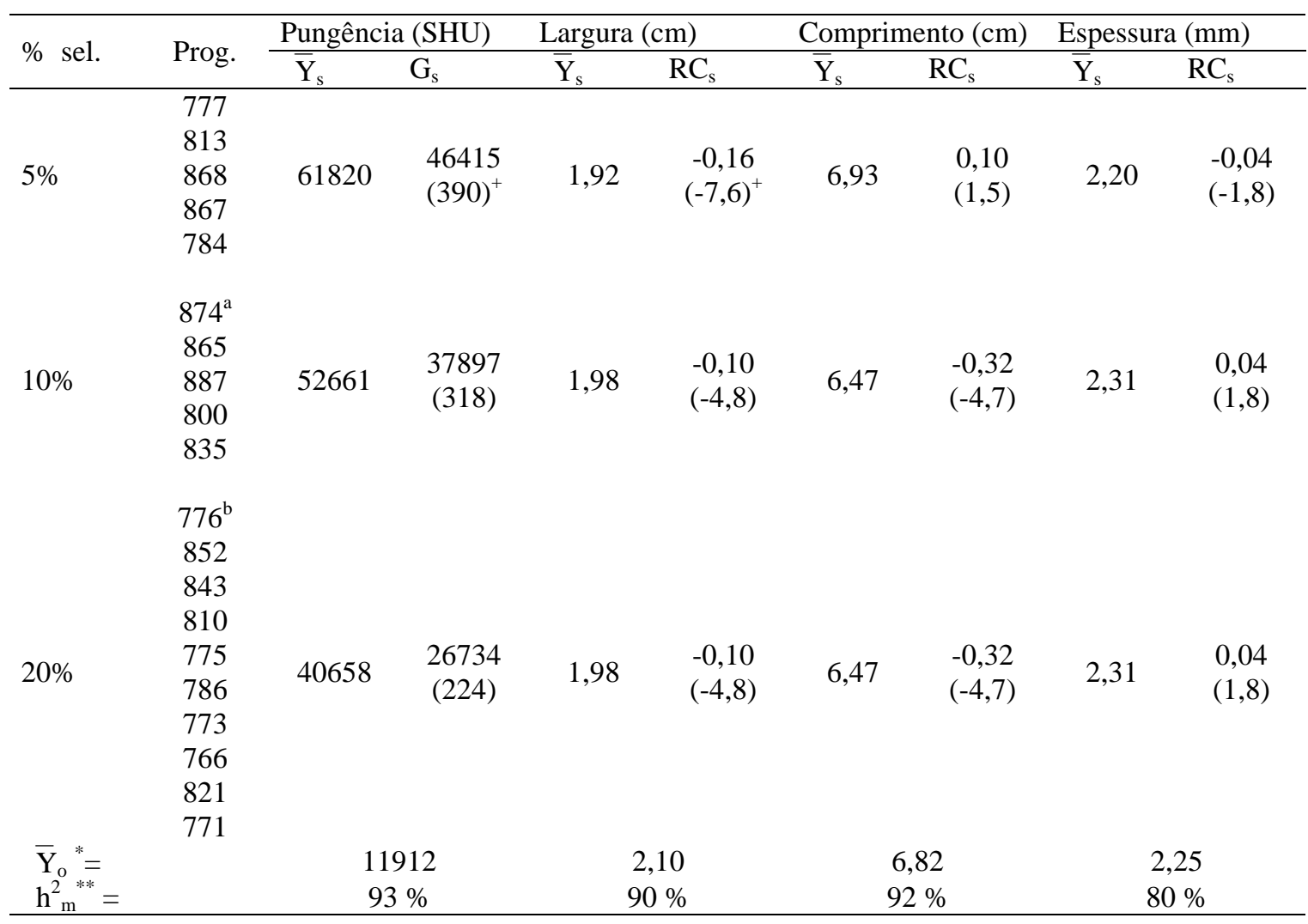

+ Entre parênteses: ganhos ou respostas correlacionadas em porcentagem da média original.

a, b: progênies selecionadas que devem ser acrescidas às anteriores.

* $\overline{\mathrm{Y}}_{\mathrm{o}}=$ média original de progênies $\mathrm{F}_{4.3}$.

$* * \mathrm{~h}_{\mathrm{m}}^{2}=$ coeficiente de herdabilidade ao nível de médias. 
Tabela 15. Progresso direto (Gs) e resposta correlacionada (RCs) na largura e comprimento do fruto e espessura da polpa com seleção para diminuição da pungência, sob diferentes pressões de seleção (\% sel. ) em progênies $F_{4.3}$ (Prog.). Capsicum annuum L. 2002.

\begin{tabular}{|c|c|c|c|c|c|c|c|c|c|}
\hline \multirow{2}{*}{$\%$ sel. } & \multirow{2}{*}{ Prog. } & \multicolumn{2}{|c|}{ Pungência (SHU) } & \multicolumn{2}{|c|}{ Largura $(\mathrm{cm})$} & \multicolumn{2}{|c|}{ Comprimento $(\mathrm{cm})$} & \multicolumn{2}{|c|}{ Espessura (mm) } \\
\hline & & $\overline{\mathrm{Y}}_{\mathrm{S}}$ & $\mathrm{G}_{\mathrm{s}}$ & $\overline{\mathrm{Y}}_{\mathrm{S}}$ & $\mathrm{RC}_{\mathrm{s}}$ & $\overline{\mathrm{Y}}_{\mathrm{s}}$ & $\mathrm{RC}_{\mathrm{s}}$ & $\overline{\mathrm{Y}}_{\mathrm{s}}$ & $\mathrm{RC}_{\mathrm{s}}$ \\
\hline $5 \%$ & $\begin{array}{l}779 \\
781 \\
789 \\
792 \\
797\end{array}$ & 0 & $\begin{array}{c}-11078 \\
(-93)^{+}\end{array}$ & 2,19 & $\begin{array}{c}0,09 \\
(4,3)^{+}\end{array}$ & 6,22 & $\begin{array}{l}-0,56 \\
(-8,2)\end{array}$ & 2,13 & $\begin{array}{l}-0,10 \\
(-4,4)\end{array}$ \\
\hline $10 \%$ & $\begin{array}{c}799^{\mathrm{a}} \\
806 \\
808 \\
809 \\
817\end{array}$ & 0 & $\begin{array}{c}-11078 \\
(-93)\end{array}$ & 2,16 & $\begin{array}{l}0,06 \\
(2,9)\end{array}$ & 6,41 & $\begin{array}{l}-0,38 \\
(-5,6)\end{array}$ & 2,22 & $\begin{array}{l}-0,03 \\
(-1,3)\end{array}$ \\
\hline $20 \%$ & $\begin{array}{c}823^{\mathrm{b}} \\
825 \\
827 \\
828 \\
829 \\
840 \\
842 \\
848 \\
851 \\
853\end{array}$ & 0 & $\begin{array}{c}-11078 \\
(-93)\end{array}$ & 2,10 & $\begin{array}{c}0,00 \\
(0)\end{array}$ & 6,67 & $\begin{array}{l}-0,14 \\
(2,0)\end{array}$ & 2,19 & $\begin{array}{l}-0,05 \\
(-2,2)\end{array}$ \\
\hline $\begin{array}{l}\overline{\mathrm{Y}}_{\mathrm{o}}{ }^{*}= \\
\mathrm{h}^{2}{ }_{\mathrm{m}}^{* *}=\end{array}$ & & & $\begin{array}{l}12 \\
\%\end{array}$ & & $\begin{array}{l}10 \\
\%\end{array}$ & & $\begin{array}{c}82 \\
\%\end{array}$ & & 25 \\
\hline
\end{tabular}

+ Entre parênteses: ganhos ou respostas correlacionadas em porcentagem da média original.

$a, b$ : progênies selecionadas que devem ser acrescidas às anteriores.

* $\overline{\mathrm{Y}}_{\mathrm{o}}=$ média original de progênies $\mathrm{F}_{4.3}$.

$* * \mathrm{~h}_{\mathrm{m}}^{2}=$ coeficiente de herdabilidade ao nível de médias. 
Tabela 16. Progresso direto (Gs) e resposta correlacionada (RCs) na produtividade, número de frutos e peso médio do fruto com seleção para aumento da pungência, sob diferentes pressões de seleção (\% sel. ) em progênies $F_{4.3}$ (Prog.). Capsicum annuum L. 2002.

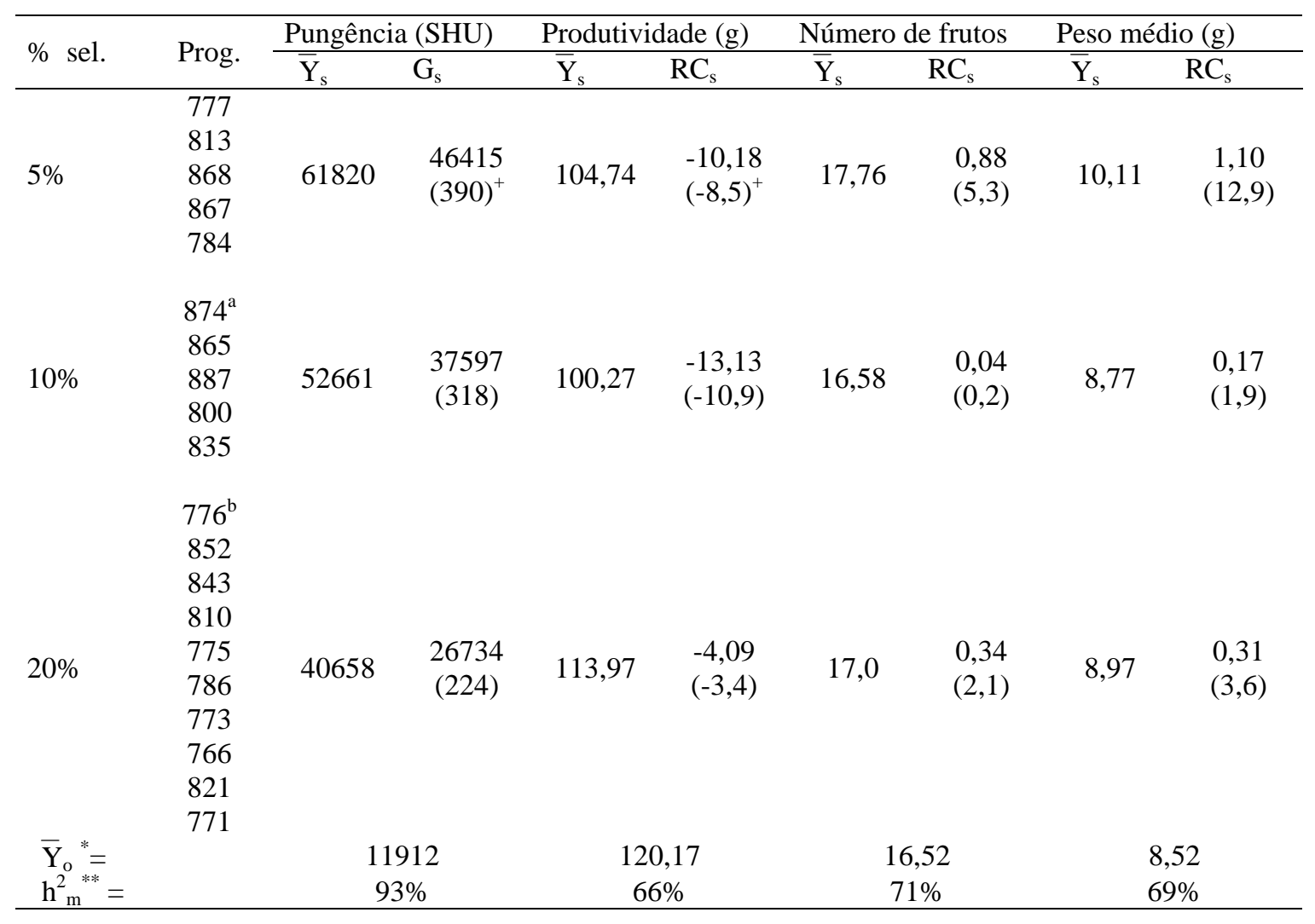

+ Entre parênteses: ganhos ou respostas correlacionadas em porcentagem da média original.

$a, b$ : progênies selecionadas que devem ser acrescidas às anteriores.

* $\overline{\mathrm{Y}}_{\mathrm{o}}=$ média original de progênies $\mathrm{F}_{4.3}$.

$* * \mathrm{~h}_{\mathrm{m}}^{2}=$ coeficiente de herdabilidade ao nível de médias. 
Tabela 17. Progresso direto (Gs) e resposta correlacionada (RCs) na produtividade, número de frutos e peso médio do fruto com seleção para diminuição da pungência, sob diferentes pressões de seleção (\% sel. ) em progênies $F_{4.3}$ (Prog.). Capsicum annuum L. 2002.

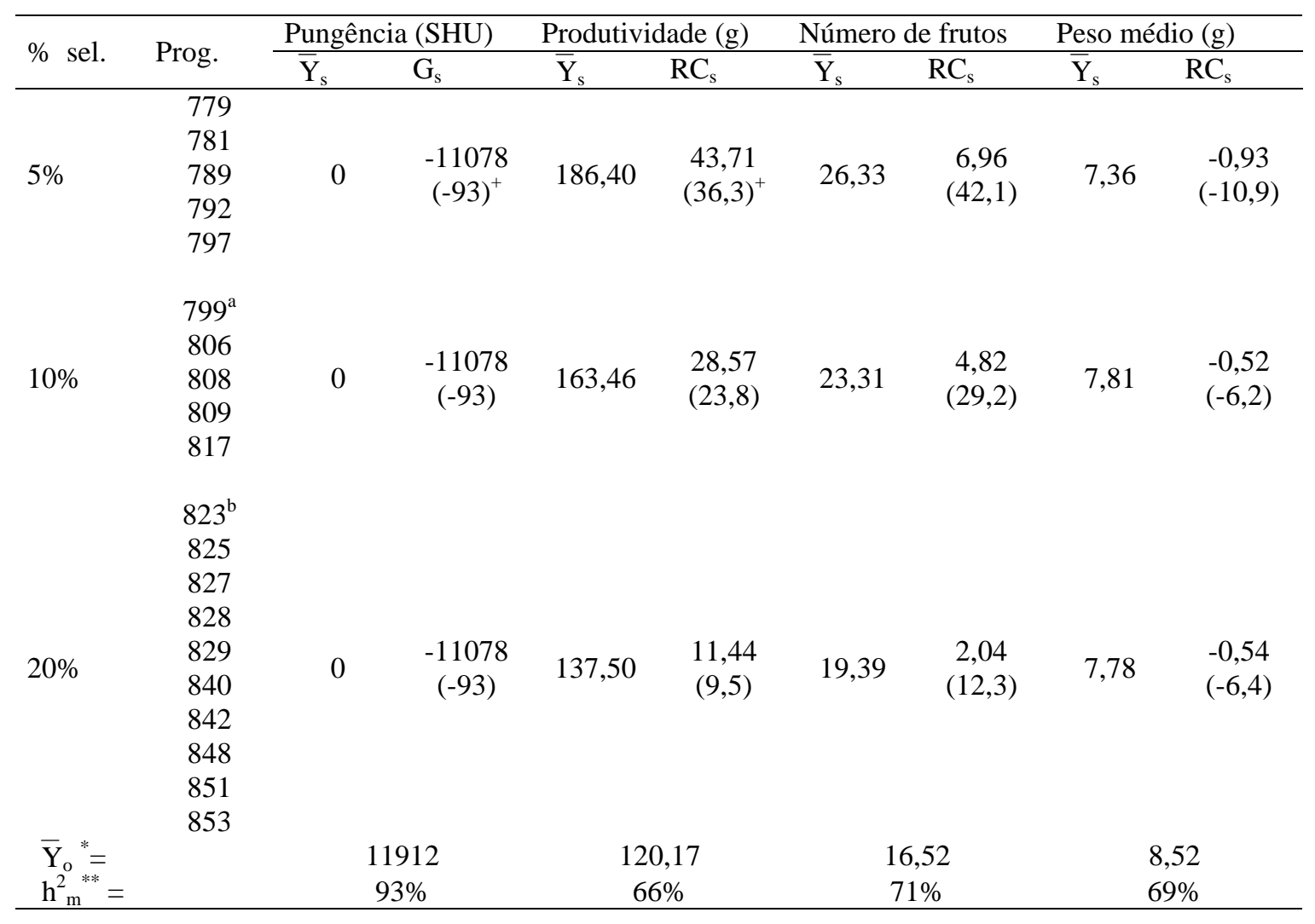

+ Entre parênteses: ganhos ou respostas correlacionadas em porcentagem da média original.

$a, b$ : progênies selecionadas que devem ser acrescidas às anteriores.

* $\overline{\mathrm{Y}}_{\mathrm{o}}=$ média original de progênies $\mathrm{F}_{4.3}$.

$* * \mathrm{~h}_{\mathrm{m}}^{2}=$ coeficiente de herdabilidade ao nível de médias. 


\section{DISCUSSÃO}

\subsection{Análises cromatográficas}

O padrão dos picos da nordiidrocapsaicina, da capsaicina e da diidrocapsaicina apresentados nos cromatogramas (Figuras 1 e 2) foi semelhante aos encontrados em estudos de Chiang (1986) e Collins et al. (1994).

$\mathrm{O}$ presença do pico não identificado, entre a capsaicina e a diidrocapsaicina lido no mesmo comprimento de onda dos capsaicinóides $(280 \mathrm{~nm})$ provavelmente, seja relativo a um capsiato (Lopes ${ }^{1}$ - informe pessoal). Esses possuem estrutura química semelhante aos capsaicinóides, apresentando o mesmo espectro de absorbância, porém são substâncias doces. Nos trabalhos consultados da literatura não foi verificada a presença deste pico em amostras de pimenta. Para identificar a substância responsável pela emissão de tal pico são necessários estudos de caráter bioquímico.

\subsection{Histogramas dos dados de pungência}

Os genitores apresentaram divergência genética adequada para o estudo da base genética da pungência. Os valores obtidos na geração $F_{1}$, para todos os capsaicinóides, demonstram a ocorrência de heterose e heterobeltiose. Excetua-se a nordiidrocapsaicina que apresentou a média da geração $F_{1}$ compreendida entre a média dos genitores, sugerindo a ocorrência de dominância parcial no sentido do genitor pungente. Esses fatos indicam que a produção de híbridos pode ser um alternativa viável para o aumento da pungência.

A ocorrência de segregação transgressiva na geração $F_{4}$ é um indício da presença de mais de um gene controlando a expressão da pungência. Outro ponto a ser considerado é que, se está ocorrendo segregação transgressiva e levando em conta que esta segregação é produzida tanto pela contribuição dos alelos do genitor masculino

1 Pesquisadora da Embrapa Agroindústria de Alimentos, 2002. 
como dos do feminino, tem-se forte indicação da existência de genes de pungência no genótipo doce. Isso permite aos melhoristas utilizarem em seus cruzamentos genótipos doces para aumentarem a pungência nos frutos de pimenta. Nos estudos consultados para a realização deste trabalho não existe nenhum relato sobre a presença de genes que controlam a expressam da pungência em genótipos doces.

Os dados de pungência da geração $\mathrm{RC}_{11}$ ficaram compreendidos entre os dos genitores em todos os capsaicinóides, porém no caso da capsaicina, diidrocapsaicina e capsaicinóides totais os valores tenderam a ficar mais próximo do genitor $\mathrm{P}_{2}$ ao invés de ficar mais próximo do genitor recorrente $\left(\mathrm{P}_{1}\right)$. Isso é um indício de que as médias de $\mathrm{RC}_{11}$ não estão se adequando ao modelo genético aditivo-dominante e que provavelmente, existam outros efeitos atuando no comportamento de tais médias.

\subsection{Análise de variância da pungência}

Apesar de terem sido tomados cuidados para diminuir, ao máximo, as causas de variação ambiental e tenha sido escolhida uma das mais eficientes metodologias de quantificação da pungência, foram encontrados altos valores do coeficiente de variação. $\mathrm{Na}$ literatura não foram relatados valores desta magnitude e o número de plantas utilizados nos experimentos foi menor (Zewdie \& Bosland, 2000a).

Os erros experimentais dos dados analisados não apresentaram distribuição normal de probabilidade $\mathrm{e}$ as variâncias não apresentaram independência e homogeneidade. Não foi encontrada uma metodologia de transformação dos dados que resolvesse esta limitação, provavelmente devido ao fato de o genitor feminino não apresentar nenhuma pungência. Assim, ocorreu a presença de valores de magnitude zero e cuja variância dos erros também foi zero, tanto para o genitor doce como em parte das progênies $F_{4.3}$. Por outro lado, foram também encontrados valores altos de pungência que variaram de 110 SHU a 77322 SHU (capsaicinóides totais). Apesar de os dados não atenderem às pressuposições para os testes $\mathrm{F}$ da análise de variância, optou-se por esta metodologia de análise em virtude da robustez do teste F (Steel \& Torrie, 1971).

Os valores de $\mathrm{F}$ calculados na análise de variância foram altos e significativos a $1 \%$ de probabilidade, para gerações e progênies e baixos e não significativos para 
blocos. Isso reforça a confiança de que existe, provavelmente, variação genética entre as progênies, para o caráter. Convém ressaltar que as estimativas dos componentes de médias e variância, bem como o ganho genético esperado com a seleção, calculado aqui por meio de diferencial de seleção, não necessitam da pressuposição de normalidade dos erros experimentais.

Foram encontrados valores altos do coeficiente de herdabilidade. Isso, indica a existência de poucos genes controlando o caráter ou um gene de efeito mais pronunciado e um complexo poligênico de efeito menos pronunciado, que regularia a expressão da pungência. Valores semelhantes de herdabilidade foram encontrados por Doshi \& Shukla (2000). Já Zewdie \& Bosland (2000a) encontram valores de herdabilidade semelhantes apenas para a nordiidrocapsaicina. Como as estimativas de herdabilidade deste trabalho foram calculadas com base em médias de parcela, é preciso ter cuidado ao compará-los com os valores obtidos em outros trabalhos. As herdabilidades estimadas para todos capsaicinóides avaliados, são válidas apenas para a população alvo do estudo e para situação de três repetições. Essa, neste caso, é uma população de interesse do programa de melhoramento genético da Embrapa Hortaliças. Outro ponto a considerar é tratar-se de uma herdabilidade no sentido amplo, ligeiramente superestimada por uma parcela da variância dominante. A obtenção desses valores altos do coeficiente de herdabilidade podem ter sido obtidos em função do alto componente de variância genética aditiva entre progênies $F_{4.3}$ (11/8); e do fato de a amplitude de variação dos dados de pungência ter sido grande. Como existe uma variação de zero a $77426 \mathrm{SHU}$, é lógico esperar altos valores da estimativa da $\sigma_{\mathrm{p}}^{2}$, o que contribui para elevação do coeficiente de herdabilidade em nível de médias de parcelas.

Dado o alto valor do coeficiente de herdabilidade em nível de parcelas, é permissível supor, baseado no bom senso do melhorista que, também o coeficiente de herdabilidade, estimado em nível de plantas seja alto, apesar de a herdabilidade adotada neste estudo, não ter sido obtida com base em plantas individuais, e possuir um viés. Com base no exposto, espera-se que parte significativa da variância aditiva seja passada às próximas gerações. Desta forma um método adequado de melhoramento seria o genealógico, onde inclusive a seleção para pungência, em se confirmando alto 
coeficiente de herdabilidade no sentido restrito, com base em plantas, poderia já ser iniciada na geração $F_{2}$ (mesmo a herdabilidade na $F_{2}$, sendo menor que na $F_{4}$, para a mesma população). Na prática dos programas de melhoramento genético de Capsicum a seleção no sentido de aumentar a pungência já em $\mathrm{F}_{2}$ vem ocorrendo com sucesso.

Outra estratégia interessante seria obter linhagens pelo método genealógico e cruzá-las para explorar o efeito de heterose, verificada nas Figuras 3 a 6. A limitação neste caso seria o alto custo da produção de híbridos e a possibilidade de parte dos híbridos produzirem pouca semente (Silva ${ }^{2}$, informe pessoal). Neste sentido é interessante que os programas de melhoramento adquiram e/ou desenvolvam linhagens macho-estéreis e realizem estudos de capacidade específica de combinação.

\subsection{Componentes de média da pungência}

As estimativas do erro padrão da média foram menores nas gerações $\mathrm{P}_{1}, \mathrm{P}_{2}, \mathrm{~F}_{1} \mathrm{e}$ $\mathrm{RC}_{11}$ do que em $\mathrm{F}_{4}$, conforme o esperado visto que, as médias da geração $\mathrm{F}_{4}$ sofrem ação de variação ambiental e genética, sendo a última maior em $\mathrm{F}_{4}$ do que em $\mathrm{RC}_{11}$.

Quando testado o modelo genético aditivo-dominante, o fato de as médias esperadas das gerações não serem semelhantes às observadas indica que tal modelo genético não é suficiente para explicar o comportamento das médias das gerações. Isso pode estar ocorrendo devido a fatores relacionados à condução do experimento e à metodologia de quantificação do caráter, ou a presença de interações não alélicas no controle da expressão da pungência.

O modelo genético de quatro parâmetros m, [a], [d] e [i] foi eficiente em explicar o comportamento das médias das gerações, o que demonstra a presença de epistasia aditiva $\mathrm{x}$ aditiva controlando a expressão da pungência (Tabela 5). Esse fato está de acordo com o comportamento dos dados de pungência do histograma da geração $\mathrm{F}_{4}$ (Figuras 3 a 6) e com os resultados obtidos do teste de $\chi^{2}$ para a hipótese de segregação fenotípica de nove pungentes para sete genótipos doces, esperada em $\mathrm{F}_{2}$ e aqui estendida para $\mathrm{F}_{4}$ devido ao processo SSD (Tabela 6). Estudos de Yagishita et al. (1990) e Zewdie

\& Bosland (2000a) também encontraram segregação de 9:7 e não significância do $\chi^{2}$ para o modelo genético incluindo epistasia. Optou-se por incluir o tipo de epistasia

2 Pesquisadora da Embrapa Hortaliças. 2002. 
aditivo $\mathrm{x}$ aditivo na geração $\mathrm{F}_{4}$, pois, pelas sucessivas gerações de auto-fecundação, espera-se maior contribuição de efeitos aditivos do que dos dominantes.

Como os genótipos utilizados neste estudo são homozigóticos e existem dois genes epistáticos controlando a pungência é possível denominar o genótipo do genitor feminino $\left(\mathrm{P}_{1}\right)$ de aabb e o do genitor masculino $\left(\mathrm{P}_{2}\right) \mathrm{AABB}$, sendo o último pungente. Desta forma a geração $\mathrm{F}_{1}$ tem genótipo $\mathrm{AaBb}$ e é pungente, conforme foi observado. $\mathrm{Na}$ geração $\mathrm{F}_{4}$ obtida como já enfatizado, pelo método SSD, espera-se que todas as progênies provenientes de ancestrais $F_{2}$ doces sejam também fenotipicamente doces. As descendentes de plantas $F_{2}$ pungentes (A_B_) no entanto, não serão necessariamente pungentes devido à amostragem inerente ao método SSD. Mesmo assim, optou-se por adotar a proporção 9:7 em $\mathrm{F}_{4}$ por ser esta a que mais se aproxima da situação real e por ser difícil prever o efeito da amostragem SSD sobre a descendência. Nota-se que para o genótipo ser considerado doce é preciso que um dos pares de alelos de um gene estejam em homozigose recessiva. O ocorrência do genótipo doce é explicada em função de o gene que está em homozigose recessiva produzir uma determinada enzima que inibe a ação da enzima produzida pela expressão do gene em dominância, resultando em ausência de pungência. Este fato não se verifica nos genótipos pungentes em função de cada par de alelos estar em homozigose dominante ou em heterozigose.

A ocorrência de epistasia explica o comportamento observado das médias avaliadas quanto à pungência, porém não explica a ocorrência de segregação transgressiva (Figuras 3 a 6). Uma alternativa seria admitir a presença de outros genes, que não estes epistáticos, presentes tanto nos genótipos doces como nos pungentes. $\mathrm{O}$ produto de tais genes só atuaria na presença de genótipos A_B_. Diversos estudos sugerem a presença de um complexo poligênico controlando a expressão da pungência (Ohta apud Greenleaf, 1986; Ribeiro \& Costa, 1990; Saccardo, 1992; Zewdie \& Bosland, 2000a). Com os dados obtidos neste estudo fica evidente que, além dos dois genes epistáticos, existe a presença de outros genes, provavelmente, de efeito menos pronunciado presentes tanto nos genótipos doces como nos pungentes e que atuam na variação dos níveis de pungência. É provável que se trate de um complexo poligênico modulador da expressão do caráter e de efeito aditivo. Porém apenas com os dados 
obtidos neste estudo não é possível tirar conclusões definitivas, sendo recomendado dar continuidade à pesquisa.

Outro ponto importante é que além de os genótipos doces provavelmente possuírem genes moduladores, ao cruzar dois genótipos doces de constituição genética distintas é possível obter na geração $\mathrm{F}_{1}$ genótipos pungentes. Isso é observado ao cruzar por exemplo, aaBB com AAbb sendo a descendência $\mathrm{AaBb}$ e portanto pungente. Assim, a escolha dos genitores em programas de melhoramento deverá ser cautelosa quando o objetivo for utilizar cruzamentos entre genótipos doces para obter indivíduos doces. Uma alternativa é utilizar técnicas de marcadores moleculares e/ou bioquímicas (isoenzimas) para auxiliar na escolha dos genitores.

Quando o objetivo for obter genótipos pungentes o melhorista também poderá optar por cruzamentos entre genótipos doces e de doces com pungentes, além dos cruzamentos entre genótipos pungentes. Nesse caso deverá tomar cuidado com o cruzamento entre genótipos pungentes em heterozigose, se por exemplo cruzar os indivíduos pungentes $\mathrm{AaBb}$ entre si, obterá genótipos pungentes e doces na proporção de 9:7, respectivamente. Assim, recomenda-se que, se o objetivo for cruzar genótipos pungentes para obter indivíduos pungentes deverá utilizar apenas linhagens homozigotas e/ou identificar a constituição alélica dos genitores por técnicas moleculares. Mesmo a constituição alélica dos genitores estando em heterozigose em alguns cruzamentos, como $\mathrm{AaBB}$ x $\mathrm{AABb}$ deverá produzir apenas descendentes pungentes; enquanto outros como $\mathrm{AaBB}$ x AaBB deverão produzir indivíduos pungentes e doces na proporção de 3:1, respectivamente.

Na população estudada, para a maioria dos genótipos avaliados, o conteúdo de capsaicina foi superior ao de diidrocapsaicina e este por sua vez, superior ao de nordiidrocapsaicina. Esta informação está de acordo com o citado na literatura para a espécie C. annuum L. (Bosland 1993; Zewdie \& Bosland 2000a), exceção feita às progênies: 795 que apresentou conteúdo de nordiidrocapsaicina superior aos demais capsaicinóides, e 769 que apresentou teor de diidrocapsaicina superior aos demais. Isso pode ter ocorrido devido ao fato de essas progênies apresentarem constituição genética distinta das demais ou em virtude de os frutos terem sido colhidos aos trinta dias após a 
antese, não dando tempo suficiente para a expressão dos demais capsaicinóides. Neste caso estar-se-ia admitindo que a expressão da nordiidrocapsaicina, apesar de menor em relação aos demais capsaicinóides é mais precoce.

Para os capsaicinóides estudados as estimativas do somatório dos efeitos de dominância foi, aproximadamente, o dobro do somatório dos efeitos de aditividade. Isso está de acordo com os valores encontrados para heterose e heterobeltiose. Este fato é um indício de que a produção de híbridos para aumentar a pungência é viável, porém, conforme mencionado, deve-se anteriormente ter cuidado na escolha dos genitores. Foi verificada a presença de heterose para capsaicina, diidrocapsicina e capsaicinóides totais. Estes valores provavelmente não estão superestimados, pois nesse caso, não existe a possibilidade do somatório dos efeitos se anularem. Isso ocorre porque não há estimativas negativas para os efeitos, devido ao fato de a média do genitor para o alelo desfavorável ser zero. Valores para os efeitos de dominância, superiores aos aditivos, também foram encontrados nos estudos de Zewdie \& Bosland (2000a).

Embora ocorra heterose e os efeitos dominantes sejam superiores aos aditivos, os últimos apresentam elevada magnitude e a ocorrência de segregação transgressiva na geração $\mathrm{F}_{4}$ indica que os efeitos aditivos são importantes na manifestação do caráter. Os efeitos epistáticos também não devem ser desprezados, pois estes são a provável causa de a média da geração $\mathrm{RC}_{11}$ estar situada entre o ponto médio dos genitores e o genitor $\mathrm{P}_{2}$, ao invés de estar mais próximo do genitor recorrente em relação ao conteúdo de capsaicina, diidrocapsaicina e capsaicinóides totais (Figuras 3 à 6). Isso também indica

que os genes epistáticos estão em associação, caso contrário o efeito de [i] seria negativo e as médias de $\mathrm{RC}_{11}$ estariam mais próximas do genitor recorrente $\left(\mathrm{P}_{1}\right)$.

\subsection{Ganho genético com seleção para pungência}

Embora os valores estimados de herdabilidade tenham sido calculados com base nas progênies $\mathrm{F}_{4.3}$, os altos valores encontrados indicam que, provavelmente, este caráter possa ser selecionado em gerações menos avançadas, utilizando alta pressão de seleção. Contudo estes valores estão superestimados devido à ocorrência de viés $\left(0,15 \sigma_{\mathrm{D}}^{2} / \sigma_{\mathrm{F}}^{2}\right)$. Outro fator que pode ter contribuído para os altos valores obtidos para a estimativa do 
Gs na pungência é o fato de este caráter ser "pouco melhorado" e neste caso a espécie também sofreu menos ação do melhoramento genético se comparada a culturas como o milho e a soja. Isso faz com que haja ampla variabilidade genética ainda, disponível para o caráter. Neste caso específico os genitores provém de grupos distintos, indicando que provavelmente, não sejam aparentados. Nos capsaicinóides totais, as médias das progênies variaram de zero a 77426 SHU (Tabela 7), o que resultou em alto valor do componente $\sigma_{p}^{2}$. Essa variação foi também foi influenciada por um forte estresse climático a que as plantas foram submetidas durante o período de transcrição dos capsaicinóides. As plantas sofreram ação de temperatura de $42^{\circ} \mathrm{C}$ e umidade relativa do ar de aproximadamente $15 \%$. No caso da pungência, quanto maiores as temperaturas e luminosidade e menor a umidade, maior será à expressão da pungência. Isso provavelmente ocorre em função de enzimas relacionadas à resposta ao estresse e que participam da via metabólica dos fenilpropanóides (Curry et al., 1999).

Tomando cautela em função do exposto até o momento, como estratégia de melhoramento provavelmente o melhorista terá maior ganho genético se aumentar o número de cruzamentos e diminuir o número de progênies geradas por cruzamento. No presente estudo, apesar de se utilizado apenas 100 progênies obtiveram-se ganhos genéticos significativos. É importante salientar que o melhorista deverá monitorar a intensidade da pressão de seleção a ser utilizada de modo a disponibilizar variabilidade genética suficiente para a seleção de outros caracteres de interesse que serão selecionados em gerações mais avançadas.

No caso de uma seleção para diminuir a pungência, como os valores do ganho genético foram reduzidos em relação à seleção no outro sentido e não variaram muito em função da pressão de seleção, é recomendado aumentar o tamanho da população a ser selecionada. Neste caso uma boa estratégia seria diminuir o número de cruzamentos em detrimento do aumento de progênies geradas em cada cruzamento, com isto aumentando a probabilidade de ocorrência de genótipos doces. Esta diminuição no ganho genético pode ter ocorrido devido à menor diversidade entre as progênies doces. Apesar do valor do Gs, no sentido de eliminar a pungência, ter sido menor do que os ganhos para aumento do caráter, mesmo assim os valores foram altos (-89\%). Isso e o 
fato de, na $\mathrm{F}_{4}$ ter ocorrido a presença de 38 progênies doces (Figuras 3 a 6 e Tabela 7) indica que a dificuldade em eliminar a pungência das populações não se deva a essa redução do ganho para diminuir em comparação com o ganho para aumentar a pungência. Mais pesquisas são necessárias para elucidar essa dificuldade. É provável que tal dificuldade esteja relacionada à constituição alélica dos genitores utilizados nos cruzamentos.

\subsection{Análise de correlação}

A correlação entre a pungência medida no fruto por análise sensorial foi de 0,63 em relação à pungência quantificada por cromatografia líquida (CLAE), sendo o último método mais preciso. Isso demonstra que em apenas uma fração dos genótipos avaliados houve coincidência entre as avaliações. Assim, se o melhorista for selecionar para aumentar a pungência baseado apenas na análise sensorial deverá aumentar o tamanho da população a ser selecionada, para obter a mesma eficiência do método cromatográfico. Por outro lado, no caso da seleção para identificar apenas os genótipos doces, o método cromatográfico não traz vantagens em relação a análise sensorial do fruto.

É recomendado dar continuidade a esta pesquisa explorando a variabilidade genética em progênies de cruzamentos entre indivíduos doces vs doce, pungentes vs pungentes, doce vs baixa pungência, doce vs média pungência e doce vs alta pungência. Dessa forma a presença de mais de um gene interferindo no controle do caráter poderá ser verificada com maior confiabilidade. A limitação em utilizar maior número de cruzamentos está no alto custo das análises cromatográficas. Nesse caso, uma alternativa seria implantar a metodologia de quantificação da pungência pelo método de Elisa e comparar os resultados com o método de cromatografia líquida de alta eficiência. Outra pesquisa interessante seria mapear QTL's associados à pungência e tentar localizar um possível complexo de genes moduladores da pungência via marcadores genéticos. Seria interessante também, auto-fecundar plantas das progênies doces e as de extrema pungência, para confirmar seu fenótipo e verificar a segregação na geração seguinte. 
Nesses tipos extremos seria interessante, também, verificar a variância entre progênies $\left(\sigma_{p}^{2}\right)$ bem como estimar o coeficiente de herdabilidade com base em plantas individuais.

A existência de genes de efeito menor, na expressão da pungência, como sugerido pelos dados deste trabalho, também deve ser levada em conta pelo melhorista. Estes devem ser importantes principalmente quando o objetivo for obter genótipos com extremos de pungência ou extremos de não pungência. Numa tal situação a seleção deverá se basear em progênies avaliadas com número adequado de repetições e a pungência avaliada por métodos precisos de quantificação, como por exemplo CLAE, elisa e ou NIR's.

\subsection{Histogramas de distribuição de freqüência dos dados de produtividade e demais caracteres do fruto}

A presença de segregação transgressiva na geração $\mathrm{F}_{4}$ em todos os caracteres avaliados indicam que os dois genitores possuem genes para aumentar os caracteres, e no caso específico do comprimento do fruto essa alteração do caráter pode se dar tanto no sentido do aumento como da diminuição do mesmo. Na largura, comprimento, produtividade e número de frutos, as médias da geração $\mathrm{F}_{1}$, exibiram heterose. $\mathrm{O}$ fato de a média da geração $F_{1}$ ser maior que a da $F_{4}$, indica uma provável ocorrência de valores de [d] maiores que os de [a]. A ocorrência de sobreposição de classe dos genitores, verificada na espessura da polpa dificulta a interpretação dos resultados obtidos no histograma das gerações (Figura 9).

\subsection{Análise de variância da produtividade e demais caracteres do fruto}

Os valores obtidos do coeficiente de variação para largura, comprimento e espessura da polpa indicam que ocorreu uma bom controle ambiental. A não significância da fonte de variação gerações, deu-se devido ao fato de as avaliações dos genitores apresentarem sobreposição de classes para espessura da polpa. Para produtividade, número e peso médio dos frutos os coeficientes de variação foram altos (Tabela 11), porém todos os valores de $\mathrm{F}$ foram significativos. As estimativas da variância ambiental tenderam a ser superiores às da variância entre progênies $\mathrm{F}_{4.3}$, o que 
contribuiu para a existência de valores intermediários do coeficiente de herdabilidade (aproximadamente 70\%). Estes valores de herdabilidade, aliados à ocorrência de segregação transgressiva em $\mathrm{F}_{4}$, são um forte indício da existência de mais de um gene responsável pela expressão destes caracteres.

\subsection{Componentes de médias da produtividade e demais caracteres do fruto}

Embora o modelo genético aditivo-dominante tenha sido suficiente para a espessura da polpa, ao se incluir o parâmetro [i] no modelo (Tabela 11), este mostra magnitude superior ao de [a], porém no sentido do genitor com alelos desfavoráveis $\left(\mathrm{P}_{2}\right)$. Assim, é conveniente considerar o modelo com [i] mais adequado para explicar o comportamento das médias das gerações. Para a espessura da polpa o efeito [d] foi negativo, o que está de acordo com o observado na Figura 9 onde a média de $F_{1}$ foi inferior às de $\mathrm{F}_{4}$, provavelmente em função de [d] estar no sentido do genitor com alelos desfavoráveis para o caráter.

As estimativas de [i] são um indício que, para a largura do fruto, os genes epistáticos, provavelmente, estejam em associação. Já para o comprimento e largura do fruto é provável que, os genes epistáticos estejam em repulsão. Porém são necessários

mais estudos para confirmar tais suspeitas. No caso da produtividade, a semelhança entre as médias de $\mathrm{F}_{1}$ com às de $\mathrm{P}_{1}$, podem estar relacionadas ao fato de as estimativas dos parâmetros m, [a] e [d] serem semelhantes.

\subsection{Resposta correlacionada à seleção para pungência, sobre a produtividade e demais caracteres do fruto}

$\mathrm{Na}$ RCs dos caracteres do fruto, após seleção para aumento da pungência, as maiores diminuições foram na largura do fruto e na produtividade. Os decréscimos na produtividade, neste caso, parecem terem sido influenciados pelas diminuições na largura e comprimento do fruto. Embora as magnitudes da diminuição da produtividade tenham oscilado entre $-3,4 \%$ e $-10,9 \%$ estes valores podem acarretar em prejuízos aos produtores. Para fins de uma melhor compreensão, admitindo uma densidade de plantio de 30000 plantas / ha (esse número varia em função do tipo de pimenta cultivada e da 
densidade de plantio) com a média geral obtida nas progênies $F_{4.3}$ de $0,1202 \mathrm{~kg}$ / planta, esta lavoura de pimenta produzirá aproximadamente 3,6 ton / ha. Ao aplicar pressão de seleção de $10 \%$ para pungência o melhorista estará criando um decréscimo de aproximadamente $393 \mathrm{~kg}$ / ha e a $20 \%$ de $123 \mathrm{~kg}$ / ha. Isto em 5 ha representa uma perda de $1965 \mathrm{~kg} /$ ha e $615 \mathrm{~kg} / \mathrm{ha}$, respectivamente. Ao considerar um plantio de $100 \mathrm{ha}$ os decréscimos serão de $39000 \mathrm{~kg} /$ ha e $12000 \mathrm{~kg} / \mathrm{ha}$, respectivamente. No Brasil, dependendo do tipo de pimenta, são encontrados cultivos que variam de aproximadamente 0,5 ha até 900 ha. $O$ preço de mercado pago às pimentas varia em função do tipo de pimenta, época de comercialização e oscilação do preço do mercado externo. No caso de Capsicum não existem estatísticas precisas quanto ao cultivo e comercialização. Apesar disso, os ganhos e as perdas em produtividade, mencionadas anteriormente, devem resultar em incrementos e prejuízos financeiros significativos, aos produtores.

Convém salientar que as estimativas das RCs estão superestimadas em função de as herdabilidades terem sido calculadas com base em médias de progênies $\mathrm{F}_{4.3}$ e terem portanto um viés para mais de $\left(0,156 \sigma_{\mathrm{D}}^{2} / \sigma_{\mathrm{F}}^{2}\right)$. A relação inversa entre pungência e produtividade, nesta população, foi provavelmente influenciada pelo fato de o genótipo pungente ter tido baixa produtividade. Tal genótipo não está adaptado à altas temperaturas, como as que ocorreram durante o período de floração e frutificação.

Para esta população, o aumento esperado da produtividade, como conseqüência de uma seleção para reduzir a pungência, parece estar relacionada com os aumentos das RCs da largura e do número de frutos (Tabelas 15 e 17 e ANEXO E). Ao admitir o mesmo exemplo abordado acima, neste caso o melhorista estaria criando um aumento de $412 \mathrm{~kg}$ / ha a $1576 \mathrm{~kg}$ / ha, dependendo da pressão de seleção aplicada. Isto em 5 ha representa acréscimo de $2062 \mathrm{~kg} /$ ha a $7880 \mathrm{~kg} /$ ha e em cultivo de $100 \mathrm{ha} 41200 \mathrm{~kg}$ / ha a $157600 \mathrm{~kg} / \mathrm{ha}$. Neste caso o impacto do aumento da produtividade tendeu a ser superior, em valor absoluto ao esperado com o decréscimo da produtividade após seleção para aumento da pungência. Isso indica que, nesta população, é possível utilizar genótipos pungentes para incorporar caracteres de interesse em populações doces, sem que haja perda de produtividade. 


\section{CONCLUSÕES}

Os resultados obtidos com a população segregante, estudada no presente trabalho, permitiram as seguintes conclusões:

1) Nos programas de melhoramento visando a pungência deve ser levada em conta a base genética desse caráter, cujos elementos principais são: a existência de dois locos com ação epistática duplo-dominante, responsáveis pela pungência e a presença de moduladores que causam variação contínua na expressão desse caráter.

2) Ao realizar cruzamentos, os melhoristas devem atentar para o fato de que genótipos doces podem conter genes para pungência, tanto nos locos de ação epistática como nos moduladores.

3) Para detectar diferenças pequenas de pungência entre genótipos é fundamental usar o método cromatográfico ao invés do sensorial.

4) Pelos altos níveis, detectados, de herdabilidade da pungência, não fica descartada a aplicação de seleção em gerações iniciais de segregação após os cruzamentos. Nessas fases iniciais, mesmo a seleção ao nível de plantas individuais deve ser considerada.

5) Ao selecionar visando a pungência, o melhorista deve atentar para as respostas correlacionadas, esperadas em outros caracteres. Isso é particularmente importante no caso da produtividade que mostra estar negativamente correlacionada com a pungência.

6) Como estratégia de melhoramento para aumento da pungência podem ser aplicadas tanto métodos de seleção de linhagens como os que visam a obtenção de híbridos. 
ANEXOS 
ANEXO A - Peso em gramas e volume em mililitros das amostras moídas de pimenta para análise de pungência nos três blocos. Capsicum annuum L. 2002.

\begin{tabular}{|c|c|c|c|c|c|c|}
\hline \multirow{2}{*}{ Genótipo } & \multicolumn{2}{|c|}{ Bloco I } & \multicolumn{2}{|c|}{ Bloco II } & \multicolumn{2}{|c|}{ Bloco III } \\
\hline & Peso & Volume & Peso & Volume & Peso & Volume \\
\hline 6-P A & 4,0 & 32 & 0,6 & 5 & 1,1 & 9 \\
\hline $6-B$ & 3,2 & 26 & 2,4 & 19 & 1,3 & 10 \\
\hline 7-P A & 8,4 & 67 & 5,1 & 41 & 12,5 & 100 \\
\hline 7-P B & 12,5 & 100 & 11,4 & 91 & 12,5 & 100 \\
\hline 7-P C & 12,5 & 100 & 12,5 & 100 & 10,7 & 86 \\
\hline $10-\mathrm{P} \mathrm{A}$ & 12,0 & 96 & 2,9 & 23 & 4,8 & 38 \\
\hline 10-P B & 8,3 & 66 & 10,5 & 84 & 1,6 & 13 \\
\hline 82-P A & 10,1 & 81 & 9,0 & 72 & 2,2 & 18 \\
\hline 82-P B & 12,5 & 100 & 12,5 & 100 & 7,1 & 57 \\
\hline 82-P C & 12,5 & 100 & 12,5 & 100 & 9,7 & 78 \\
\hline 766 & 9,3 & 74 & 4,8 & 38 & 8,4 & 67 \\
\hline 769 & 12,5 & 100 & 12,2 & 100 & - & - \\
\hline 771 & 4,5 & 36 & 9,2 & 74 & - & - \\
\hline 773 & - & - & 2,2 & 18 & 1,9 & 15 \\
\hline 774 & - & - & 5,7 & 46 & 12,5 & 100 \\
\hline 775 & 2,6 & 21 & 12,5 & 100 & 12,5 & 100 \\
\hline 776 & 12,5 & 100 & 7,8 & 62 & 10 & 82 \\
\hline 777 & 7,4 & 59 & 10,1 & 81 & 12,5 & 100 \\
\hline 779 & 12,5 & 100 & 12,5 & 100 & 12,1 & 97 \\
\hline 780 & 3,9 & 31 & 12,5 & 100 & 12,5 & 100 \\
\hline 781 & 12,5 & 100 & 12,5 & 100 & 12,5 & 100 \\
\hline 782 & 12,2 & 98 & 8,2 & 66 & 9,2 & 74 \\
\hline 783 & 9,3 & 74 & 12,5 & 100 & 12,5 & 100 \\
\hline 784 & 10,9 & 87 & 6,3 & 50 & - & - \\
\hline 785 & 2,3 & 18 & 8,9 & 71 & 12,5 & 100 \\
\hline 786 & 3,9 & 31 & 12,5 & 100 & 12,5 & 100 \\
\hline 787 & 10,4 & 83 & 12,5 & 100 & 12,4 & 99 \\
\hline 789 & 12,5 & 100 & 11,6 & 93 & 12,5 & 100 \\
\hline 790 & 6,0 & 48 & 12,5 & 100 & 12,4 & 99 \\
\hline 791 & 1,4 & 11 & 7,4 & 59 & 0,7 & 6 \\
\hline 792 & 3,2 & 26 & 1,0 & 8 & 1,1 & 9 \\
\hline 795 & 0,9 & 7 & 0,3 & 2,4 & 9,0 & 72 \\
\hline 796 & 12,5 & 100 & 11,9 & 95 & 7,5 & 60 \\
\hline 797 & 12,5 & 100 & 11,7 & 94 & 12,5 & 100 \\
\hline 799 & 7,7 & 62 & 12,5 & 100 & 6,1 & 49 \\
\hline
\end{tabular}


ANEXO A - Peso em gramas e volume em mililitros das amostras moídas de pimenta para análise de pungência nos três blocos. Capsicum annuum L. 2002.

\begin{tabular}{|c|c|c|c|c|c|c|}
\hline \multirow{2}{*}{ Genótipo } & \multicolumn{2}{|c|}{ Bloco I } & \multicolumn{2}{|c|}{ Bloco II } & \multicolumn{2}{|c|}{ Bloco III } \\
\hline & Peso & Volume & Peso & Volume & Peso & Volume \\
\hline 800 & 12,5 & 100 & 12,5 & 100 & 12,5 & 100 \\
\hline 802 & 12,5 & 100 & 12,5 & 100 & 2,4 & 19 \\
\hline 803 & 12,5 & 100 & 3,8 & 30 & 5,5 & 44 \\
\hline 804 & 12,5 & 100 & 12,5 & 100 & 11,9 & 95 \\
\hline 806 & 1,8 & 14 & 10,8 & 86 & 12,5 & 100 \\
\hline 807 & 12,5 & 100 & 12,5 & 100 & 12,5 & 100 \\
\hline 808 & 12,5 & 100 & 12,5 & 100 & 9,5 & 76 \\
\hline 809 & 12,5 & 100 & 8,0 & 64 & 7,8 & 62 \\
\hline 810 & 12,5 & 100 & 12,5 & 100 & 12,5 & 100 \\
\hline 811 & 12,5 & 100 & 7,0 & 56 & 12,5 & 100 \\
\hline 813 & 12,5 & 100 & 7,6 & 61 & - & - \\
\hline 817 & 4,1 & 33 & - & - & 9,8 & 78 \\
\hline 819 & 3,1 & 25 & 8,1 & 65 & 4,0 & 32 \\
\hline 821 & 12,5 & 100 & 12,5 & 100 & 12,5 & 100 \\
\hline 822 & 12,5 & 100 & 8,7 & 70 & - & - \\
\hline 823 & 12,5 & 100 & 12,5 & 100 & 3,1 & 25 \\
\hline 824 & 12,5 & 100 & - & - & 5,6 & 45 \\
\hline 825 & 8,9 & 71 & 9,7 & 78 & 12,5 & 100 \\
\hline 826 & 3,7 & 30 & 5,9 & 47 & 4,6 & 37 \\
\hline 827 & 12,5 & 100 & 12,5 & 100 & 12,5 & 100 \\
\hline 828 & - & - & 4,7 & 38 & 1,3 & 10 \\
\hline 829 & 10,5 & 84 & 12,5 & 100 & 2,7 & 6 \\
\hline 830 & 2,9 & 23 & 4,5 & 36 & 5,6 & 45 \\
\hline 831 & 4,9 & 39 & 3,7 & 30 & 5,8 & 46 \\
\hline 832 & 12,5 & 100 & 12,5 & 100 & 12,5 & 100 \\
\hline 833 & 4,1 & 33 & 1,3 & 10 & - & - \\
\hline 835 & 8,4 & 67 & 12,5 & 100 & 6,5 & 52 \\
\hline 836 & 2,0 & 16 & 5,1 & 41 & 12,5 & 100 \\
\hline 839 & 4,3 & 34 & 9,7 & 78 & 3,5 & 28 \\
\hline 840 & 12,5 & 100 & 11,7 & 94 & 10,8 & 86 \\
\hline 842 & 2,2 & 18 & 3,2 & 26 & 9,2 & 74 \\
\hline 843 & 12,5 & 100 & 10,18 & 81 & 12,5 & 100 \\
\hline 844 & 5,8 & 46 & 10,5 & 84 & 9,3 & 74 \\
\hline 845 & 10,8 & 86 & 4,5 & 36 & 1,6 & 13 \\
\hline
\end{tabular}


ANEXO A - Peso em gramas e volume em mililitros das amostras moídas de pimenta para análise de pungência nos três blocos. Capsicum annuum L. 2002.

\begin{tabular}{|c|c|c|c|c|c|c|}
\hline \multirow{2}{*}{ Genótipo } & \multicolumn{2}{|c|}{ Bloco I } & \multicolumn{2}{|c|}{ Bloco II } & \multicolumn{2}{|c|}{ Bloco III } \\
\hline & Peso & Volume & Peso & Volume & Peso & Volume \\
\hline 846 & 12,5 & 100 & 12,5 & 100 & 8,9 & 71 \\
\hline 847 & 11,4 & 91 & 12,5 & 100 & 12,5 & 100 \\
\hline 848 & 12,5 & 100 & 12,5 & 100 & 12,5 & 100 \\
\hline 849 & 11,5 & 92 & 9,0 & 72 & 12,5 & 100 \\
\hline 850 & 7,7 & 62 & 12 & 96 & 8,9 & 71 \\
\hline 851 & 12,5 & 100 & 12,5 & 100 & 11,1 & 89 \\
\hline 852 & 12,5 & 100 & 12,5 & 100 & 12,5 & 100 \\
\hline 853 & 11,8 & 94 & 12,5 & 100 & 12,5 & 100 \\
\hline 855 & 2,4 & 19 & 12,5 & 100 & 7,0 & 56 \\
\hline 856 & 12,5 & 100 & 6,6 & 53 & - & - \\
\hline 857 & 12,5 & 100 & 12,5 & 100 & 12,5 & 100 \\
\hline 858 & 7,3 & 58 & 5,5 & 44 & 6,0 & 48 \\
\hline 859 & 12,5 & 100 & 12,5 & 100 & 12,2 & 98 \\
\hline 862 & 10 & 80 & 12,5 & 100 & 12,5 & 100 \\
\hline 863 & 12,5 & 100 & 11,2 & 90 & 12,5 & 100 \\
\hline 864 & 9,3 & 74 & 11,9 & 95 & 12,5 & 100 \\
\hline 865 & 4,9 & 39 & 5,0 & 40 & 4,7 & 38 \\
\hline 866 & 9,4 & 75 & 9,4 & 75 & 9,6 & 77 \\
\hline 867 & 10,4 & 83 & 8,1 & 65 & 2,3 & 18 \\
\hline 868 & 12,5 & 100 & 12,5 & 100 & 12 & 97 \\
\hline 869 & 12,5 & 100 & 12,5 & 100 & - & - \\
\hline 870 & 3,4 & 27 & 12,0 & 96 & 7,0 & 56 \\
\hline 871 & 6,1 & 49 & 10,0 & 80 & 12,5 & 100 \\
\hline 872 & 4,5 & 36 & 6,9 & 55 & - & - \\
\hline 873 & 11,3 & 90 & 12,5 & 100 & 12,5 & 100 \\
\hline 874 & 12,5 & 100 & 8,8 & 70 & 12,5 & 100 \\
\hline 875 & 7,6 & 61 & 12,5 & 100 & 9,4 & 75 \\
\hline 876 & 3,5 & 28 & 7,0 & 56 & 12,5 & 100 \\
\hline 877 & 9,4 & 75 & 12,5 & 100 & 12,5 & 100 \\
\hline 878 & 3,9 & 31 & 10,1 & 81 & 10,5 & 84 \\
\hline 879 & - & - & 8,7 & 70 & 2,3 & 18 \\
\hline 880 & 11,5 & 92 & 9,1 & 73 & 12,5 & 100 \\
\hline 881 & 5,8 & 46 & 7,6 & 61 & 12,3 & 98 \\
\hline 882 & 8,2 & 66 & 8,7 & 70 & 8,6 & 69 \\
\hline
\end{tabular}


ANEXO A - Peso em gramas e volume em mililitros das amostras moídas de pimenta para análise de pungência nos três blocos. Capsicum annuum L. 2002.

\begin{tabular}{|c|c|c|c|c|c|c|}
\hline \multirow{2}{*}{ Genótipo } & \multicolumn{2}{|c|}{ Bloco I } & \multicolumn{2}{|c|}{ Bloco II } & \multicolumn{2}{|c|}{ Bloco III } \\
\hline & Peso & Volume & Peso & Volume & Peso & Volume \\
\hline 884 & 11,3 & 90 & - & - & 12,2 & 98 \\
\hline 885 & 12,5 & 100 & 12,5 & 100 & 12,5 & 100 \\
\hline 886 & 11,0 & 88 & 10,2 & 82 & 12,5 & 100 \\
\hline 887 & 2,9 & 23 & 3,8 & 30 & - & - \\
\hline 888 & 11,9 & 95 & 12,5 & 100 & 8,6 & 69 \\
\hline 889 & 9,7 & 78 & 9,2 & 74 & 12,5 & 100 \\
\hline 890 & 9,5 & 76 & 12,5 & 100 & 12,5 & 100 \\
\hline 891 & 1,4 & 11 & 10,8 & 86 & 10,8 & 86 \\
\hline 892 & 12,5 & 100 & 3,7 & 30 & 12,5 & 100 \\
\hline
\end{tabular}


ANEXO B - Dados de nordiidrocapsaicina (Nordiidro), capsaicina, diidrocapsaicina (Diidro) e capsaicinóides totais (Caps. Totais) em SHU nos três blocos para as gerações $\mathrm{P}_{1}, \mathrm{P}_{2}, \mathrm{~F}_{1}, \mathrm{~F}_{4}$ e $\mathrm{RC}_{11}$. Capsicum annuum L. 2002.

\begin{tabular}{|c|c|c|c|c|c|c|c|}
\hline Geração & Genótipo & Bloco & Parcela & Nordiidro & Capsaicina & Diidro & Caps. Totais \\
\hline $\mathrm{P} 2$ & 6 & 1 & 1 & 1471 & 12630 & 8379 & 22480 \\
\hline P2 & 6 & 1 & 2 & 1205 & 10352 & 6868 & 18426 \\
\hline P2 & 6 & 2 & 1 & 1790 & 12007 & 14622 & 28419 \\
\hline P2 & 6 & 2 & 2 & 1450 & 9722 & 11840 & 23011 \\
\hline P2 & 6 & 3 & 1 & 731 & 17560 & 6702 & 24993 \\
\hline P2 & 6 & 3 & 2 & 1707 & 12764 & 15513 & 29984 \\
\hline P1 & 7 & 1 & 1 & 0 & 0 & 0 & 0 \\
\hline $\mathrm{P} 1$ & 7 & 1 & 2 & 0 & 0 & 0 & 0 \\
\hline P1 & 7 & 1 & 3 & 0 & 0 & 0 & 0 \\
\hline $\mathrm{P} 1$ & 7 & 2 & 1 & 0 & 0 & 0 & 0 \\
\hline P1 & 7 & 2 & 2 & 0 & 0 & 0 & 0 \\
\hline P1 & 7 & 2 & 3 & 0 & 0 & 0 & 0 \\
\hline P1 & 7 & 3 & 1 & 0 & 0 & 0 & 0 \\
\hline P1 & 7 & 3 & 2 & 0 & 0 & 0 & 0 \\
\hline P1 & 7 & 3 & 3 & 0 & 0 & 0 & 0 \\
\hline $\mathrm{F} 1$ & 10 & 1 & 1 & 1366 & 19006 & 18882 & 39253 \\
\hline F1 & 10 & 1 & 2 & 1166 & 28598 & 15470 & 45235 \\
\hline F1 & 10 & 2 & 1 & 1053 & 26695 & 14707 & 42455 \\
\hline F1 & 10 & 2 & 2 & 649 & 18306 & 10373 & 29328 \\
\hline $\mathrm{F} 1$ & 10 & 3 & 1 & 924 & 29465 & 16390 & 46779 \\
\hline F1 & 10 & 3 & 2 & 826 & 23057 & 13029 & 36912 \\
\hline RC11 & 82 & 1 & 1 & 127 & 7907 & 3292 & 11326 \\
\hline RC11 & 82 & 1 & 2 & 249 & 5969 & 3675 & 9893 \\
\hline RC11 & 82 & 2 & 1 & 161 & 4187 & 1828 & 6175 \\
\hline RC11 & 82 & 2 & 2 & 792 & 12912 & 9445 & 23150 \\
\hline RC11 & 82 & 3 & 1 & 392 & 11616 & 5333 & 17342 \\
\hline RC11 & 82 & 3 & 2 & 377 & 10511 & 4404 & 15292 \\
\hline RC11 & 82 & 3 & 3 & 583 & 7963 & 5570 & 14116 \\
\hline $\mathrm{F} 4$ & 766 & 1 & 1 & 679 & 9949 & 8764 & 19392 \\
\hline F4 & 766 & 2 & 1 & 896 & 12035 & 10914 & 23845 \\
\hline $\mathrm{F} 4$ & 766 & 3 & 1 & 679 & 15007 & 10257 & 25943 \\
\hline F4 & 769 & 1 & 1 & 0 & 0 & 0 & 0 \\
\hline $\mathrm{F} 4$ & 769 & 2 & 1 & 0 & 0 & 221 & 221 \\
\hline F4 & 769 & 3 & 1 & & & & \\
\hline $\mathrm{F} 4$ & 771 & 1 & 1 & 835 & 7045 & 5081 & 12962 \\
\hline F4 & 771 & 2 & 1 & 1493 & 16461 & 11499 & 29452 \\
\hline $\mathrm{F} 4$ & 771 & 3 & 1 & & & & \\
\hline F4 & 773 & 1 & 1 & & & & \\
\hline F4 & 773 & 2 & 1 & 1395 & 17290 & 15126 & 33811 \\
\hline F4 & 773 & 3 & 1 & 1035 & 10941 & 12741 & 24717 \\
\hline $\mathrm{F} 4$ & 774 & 2 & 1 & & & & \\
\hline $\mathrm{F} 4$ & 774 & 2 & 1 & 213 & 6023 & 2135 & 8370 \\
\hline $\mathrm{F} 4$ & 774 & 3 & 1 & 481 & 14373 & 6095 & 20949 \\
\hline F4 & 775 & 1 & 1 & 2325 & 18088 & 10766 & 31179 \\
\hline
\end{tabular}


ANEXO B - Dados de nordiidrocapsaicina (Nordiidro), capsaicina, diidrocapsaicina (Diidro) e capsaicinóides totais (Caps. Totais) em SHU nos três blocos para as gerações $\mathrm{P}_{1}, \mathrm{P}_{2}, \mathrm{~F}_{1}, \mathrm{~F}_{4}$ e $\mathrm{RC}_{11}$. Capsicum annuum L. 2002.

\begin{tabular}{|c|c|c|c|c|c|c|c|}
\hline Geração & Genótipo & Bloco & Parcela & Nordiidro & Capsaicina & Diidro & Caps. Totais \\
\hline F4 & 775 & 2 & 1 & 1692 & 21918 & 11434 & 35044 \\
\hline F4 & 775 & 3 & 1 & 1050 & 13288 & 10548 & 24885 \\
\hline $\mathrm{F} 4$ & 776 & 1 & 1 & 1796 & 14595 & 15060 & 31451 \\
\hline F4 & 776 & 2 & 1 & 1375 & 21556 & 14265 & 37197 \\
\hline F4 & 776 & 3 & 1 & 1455 & 23114 & 13758 & 38326 \\
\hline F4 & 777 & 1 & 1 & 3724 & 45192 & 25412 & 74328 \\
\hline $\mathrm{F} 4$ & 777 & 2 & 1 & 3185 & 43282 & 20949 & 67416 \\
\hline $\mathrm{F} 4$ & 777 & 3 & 1 & 3333 & 58433 & 28456 & 90222 \\
\hline F4 & 779 & 1 & 1 & 0 & 0 & 0 & 0 \\
\hline F4 & 779 & 2 & 1 & 0 & 0 & 0 & 0 \\
\hline $\mathrm{F} 4$ & 779 & 3 & 1 & 0 & 0 & 0 & 0 \\
\hline F4 & 780 & 1 & 1 & 399 & 6684 & 3189 & 10271 \\
\hline F4 & 780 & 2 & 1 & 467 & 4591 & 3574 & 8632 \\
\hline F4 & 780 & 3 & 1 & 640 & 10676 & 7098 & 18414 \\
\hline F4 & 781 & 1 & 1 & 0 & 0 & 0 & 0 \\
\hline F4 & 781 & 2 & 1 & 0 & 0 & 0 & 0 \\
\hline F4 & 781 & 3 & 1 & 0 & 0 & 0 & 0 \\
\hline F4 & 782 & 1 & 1 & 0 & 279 & 0 & 279 \\
\hline F4 & 782 & 2 & 1 & 0 & 290 & 656 & 946 \\
\hline F4 & 782 & 3 & 1 & 831 & 1279 & 0 & 2110 \\
\hline F4 & 783 & 1 & 1 & 406 & 7430 & 4661 & 12498 \\
\hline F4 & 783 & 2 & 1 & 349 & 9853 & 2641 & 12843 \\
\hline F4 & 783 & 3 & 1 & 586 & 14027 & 5860 & 20472 \\
\hline $\mathrm{F} 4$ & 784 & 1 & 1 & 1339 & 25523 & 19652 & 46515 \\
\hline F4 & 784 & 2 & 1 & 1678 & 32490 & 18371 & 52539 \\
\hline F4 & 784 & 3 & 1 & & & & \\
\hline F4 & 785 & 1 & 1 & 239 & 2680 & 1748 & 4668 \\
\hline $\mathrm{F} 4$ & 785 & 2 & 1 & 0 & 180 & 0 & 180 \\
\hline F4 & 785 & 3 & 1 & 179 & 1086 & 708 & 1973 \\
\hline F4 & 786 & 1 & 1 & 639 & 12929 & 9479 & 23047 \\
\hline F4 & 786 & 2 & 1 & 658 & 18118 & 7870 & 26646 \\
\hline F4 & 786 & 3 & 1 & 819 & 25782 & 12060 & 38661 \\
\hline F4 & 787 & 1 & 1 & 0 & 956 & 0 & 956 \\
\hline F4 & 787 & 2 & 1 & 0 & 0 & 0 & 0 \\
\hline F4 & 787 & 3 & 1 & 0 & 2095 & 825 & 2920 \\
\hline F4 & 789 & 1 & 1 & 0 & 0 & 0 & 0 \\
\hline $\mathrm{F} 4$ & 789 & 2 & 1 & 0 & 0 & 0 & 0 \\
\hline F4 & 789 & 3 & 1 & 0 & 0 & 0 & 0 \\
\hline F4 & 790 & 1 & 1 & 0 & 0 & 0 & 0 \\
\hline F4 & 790 & 2 & 1 & 0 & 156 & 286 & 442 \\
\hline $\mathrm{F} 4$ & 790 & 3 & 1 & 0 & 0 & 0 & 0 \\
\hline F4 & 791 & 1 & 1 & 0 & 532 & 0 & 532 \\
\hline F4 & 791 & 2 & 1 & 135 & 2099 & 1002 & 3236 \\
\hline F4 & 791 & 3 & 1 & 0 & 0 & 0 & 0 \\
\hline
\end{tabular}


ANEXO B - Dados de nordiidrocapsaicina (Nordiidro), capsaicina, diidrocapsaicina (Diidro) e capsaicinóides totais (Caps. Totais) em SHU nos três blocos para as gerações $\mathrm{P}_{1}, \mathrm{P}_{2}, \mathrm{~F}_{1}, \mathrm{~F}_{4}$ e $\mathrm{RC}_{11}$. Capsicum annuum L. 2002.

\begin{tabular}{|c|c|c|c|c|c|c|c|}
\hline Geração & Genótipo & Bloco & Parcela & Nordiidro & Capsaicina & Diidro & Caps. Totais \\
\hline $\mathrm{F} 4$ & 792 & 1 & 1 & 0 & 0 & 0 & 0 \\
\hline F4 & 792 & 2 & 1 & 0 & 0 & 0 & 0 \\
\hline F4 & 792 & 3 & 1 & 0 & 0 & 0 & 0 \\
\hline $\mathrm{F} 4$ & 795 & 1 & 1 & 357 & 0 & 0 & 357 \\
\hline F4 & 795 & 2 & 1 & 0 & 0 & 0 & 0 \\
\hline $\mathrm{F} 4$ & 795 & 3 & 1 & 0 & 0 & 0 & 0 \\
\hline F4 & 796 & 1 & 1 & 341 & 4785 & 4188 & 9314 \\
\hline $\mathrm{F} 4$ & 796 & 2 & 1 & 314 & 6458 & 3285 & 10056 \\
\hline F4 & 796 & 3 & 1 & 633 & 15841 & 8163 & 24637 \\
\hline $\mathrm{F} 4$ & 797 & 1 & 1 & 0 & 0 & 0 & 0 \\
\hline F4 & 797 & 2 & 1 & 0 & 0 & 0 & 0 \\
\hline F4 & 797 & 3 & 1 & 0 & 0 & 0 & 0 \\
\hline F4 & 799 & 1 & 1 & 0 & 0 & 0 & 0 \\
\hline $\mathrm{F} 4$ & 799 & 2 & 1 & 0 & 0 & 0 & 0 \\
\hline F4 & 799 & 3 & 1 & 0 & 0 & 0 & 0 \\
\hline $\mathrm{F} 4$ & 800 & 1 & 1 & 2503 & 27285 & 19770 & 49559 \\
\hline $\mathrm{F} 4$ & 800 & 2 & 1 & 1522 & 27670 & 12142 & 41334 \\
\hline $\mathrm{F} 4$ & 800 & 3 & 1 & 1467 & 20920 & 12601 & 34987 \\
\hline $\mathrm{F} 4$ & 802 & 1 & 1 & 818 & 10260 & 9916 & 20994 \\
\hline F4 & 802 & 2 & 1 & 575 & 11871 & 6809 & 19255 \\
\hline $\mathrm{F} 4$ & 802 & 3 & 1 & 541 & 15329 & 4489 & 20359 \\
\hline F4 & 803 & 1 & 1 & 214 & 4682 & 1807 & 6703 \\
\hline F4 & 803 & 2 & 1 & 0 & 0 & 0 & 0 \\
\hline F4 & 803 & 3 & 1 & 0 & 0 & 0 & 0 \\
\hline F4 & 804 & 1 & 1 & 564 & 6661 & 5949 & 13174 \\
\hline F4 & 804 & 2 & 1 & 280 & 4759 & 2452 & 7491 \\
\hline $\mathrm{F} 4$ & 804 & 3 & 1 & 479 & 6547 & 1985 & 9011 \\
\hline F4 & 806 & 1 & 1 & 0 & 0 & 0 & 0 \\
\hline F4 & 806 & 2 & 1 & 0 & 0 & 0 & 0 \\
\hline F4 & 806 & 3 & 1 & 0 & 0 & 0 & 0 \\
\hline $\mathrm{F} 4$ & 807 & 1 & 1 & 329 & 7904 & 5002 & 13235 \\
\hline F4 & 807 & 2 & 1 & 397 & 18179 & 6893 & 25469 \\
\hline $\mathrm{F} 4$ & 807 & 3 & 1 & 247 & 7653 & 2998 & 10899 \\
\hline $\mathrm{F} 4$ & 808 & 1 & 1 & 0 & 0 & 0 & 0 \\
\hline $\mathrm{F} 4$ & 808 & 2 & 1 & 0 & 0 & 0 & 0 \\
\hline $\mathrm{F} 4$ & 808 & 3 & 1 & 0 & 0 & 0 & 0 \\
\hline F4 & 809 & 1 & 1 & 0 & 0 & 0 & 0 \\
\hline $\mathrm{F} 4$ & 809 & 2 & 1 & 0 & 0 & 0 & 0 \\
\hline $\mathrm{F} 4$ & 809 & 3 & 1 & 0 & 0 & 0 & 0 \\
\hline $\mathrm{F} 4$ & 810 & 1 & 1 & 1065 & 16128 & 16676 & 33869 \\
\hline F4 & 810 & 2 & 1 & 439 & 20847 & 8535 & 29821 \\
\hline $\mathrm{F} 4$ & 810 & 3 & 1 & 469 & 18726 & 9741 & 28936 \\
\hline F4 & 811 & 1 & 1 & 0 & 0 & 0 & 0 \\
\hline $\mathrm{F} 4$ & 811 & 2 & 1 & 0 & 322 & 650 & 971 \\
\hline
\end{tabular}


ANEXO B - Dados de nordiidrocapsaicina (Nordiidro), capsaicina, diidrocapsaicina (Diidro) e capsaicinóides totais (Caps. Totais) em SHU nos três blocos para as gerações $\mathrm{P}_{1}, \mathrm{P}_{2}, \mathrm{~F}_{1}$, $\mathrm{F}_{4}$ e $\mathrm{RC}_{11 .}$ Capsicum annuum L. 2002.

\begin{tabular}{|c|c|c|c|c|c|c|c|}
\hline Geração & Genótipo & Bloco & Parcela & Nordiidro & Capsaicina & Diidro & Caps. Totais \\
\hline$\overline{\mathrm{F} 4}$ & 811 & 3 & 1 & 0 & 0 & 0 & $\overline{0}$ \\
\hline F4 & 813 & 1 & 1 & 1268 & 32776 & 25920 & 59964 \\
\hline F4 & 813 & 2 & 1 & 1391 & 58780 & 26718 & 86889 \\
\hline F4 & 813 & 3 & 1 & & & & \\
\hline F4 & 817 & 1 & 1 & 0 & 0 & 0 & 0 \\
\hline F4 & 817 & 3 & 1 & 0 & 0 & 0 & 0 \\
\hline F4 & 819 & 1 & 1 & 114 & 7163 & 2657 & 9934 \\
\hline F4 & 819 & 2 & 1 & 338 & 10313 & 4662 & 15313 \\
\hline F4 & 819 & 3 & 1 & 407 & 8483 & 3457 & 12348 \\
\hline F4 & 821 & 1 & 1 & 858 & 12150 & 10536 & 23543 \\
\hline F4 & 821 & 2 & 1 & 429 & 12815 & 6895 & 20140 \\
\hline F4 & 821 & 3 & 1 & 729 & 11974 & 9010 & 21713 \\
\hline $\mathrm{F} 4$ & 822 & 1 & 1 & 283 & 5259 & 3332 & 8874 \\
\hline F4 & 822 & 2 & 1 & 88 & 3706 & 1319 & 5113 \\
\hline F4 & 822 & 3 & 1 & & & & \\
\hline F4 & 823 & 1 & 1 & 0 & 0 & 0 & 0 \\
\hline $\mathrm{F} 4$ & 823 & 2 & 1 & 0 & 0 & 0 & 0 \\
\hline F4 & 823 & 3 & 1 & 0 & 0 & 0 & 0 \\
\hline F4 & 824 & 1 & 1 & 1095 & 13287 & 8597 & 22978 \\
\hline F4 & 824 & 2 & 1 & & & & \\
\hline F4 & 824 & 3 & 1 & 810 & 10940 & 6925 & 18675 \\
\hline $\mathrm{F} 4$ & 825 & 1 & 1 & 0 & 0 & 0 & 0 \\
\hline F4 & 825 & 2 & 1 & 0 & 0 & 0 & 0 \\
\hline $\mathrm{F} 4$ & 825 & 3 & 1 & 0 & 0 & 0 & 0 \\
\hline F4 & 826 & 1 & 1 & 0 & 0 & 0 & 0 \\
\hline F4 & 826 & 2 & 1 & 0 & 1569 & 723 & 2292 \\
\hline F4 & 826 & 3 & 1 & 258 & 5944 & 3282 & 9484 \\
\hline F4 & 827 & 1 & 1 & 0 & 0 & 0 & 0 \\
\hline F4 & 827 & 2 & 1 & 0 & 0 & 0 & 0 \\
\hline F4 & 827 & 3 & 1 & 0 & 0 & 0 & 0 \\
\hline F4 & 828 & 1 & 1 & & & & \\
\hline $\mathrm{F} 4$ & 828 & 2 & 1 & 0 & 0 & 0 & 0 \\
\hline F4 & 828 & 3 & 1 & 0 & 0 & 0 & 0 \\
\hline F4 & 829 & 1 & 1 & 0 & 0 & 0 & 0 \\
\hline F4 & 829 & 2 & 1 & 0 & 0 & 0 & 0 \\
\hline F4 & 829 & 3 & 1 & 0 & 0 & 0 & 0 \\
\hline F4 & 830 & 1 & 1 & 329 & 3003 & 1747 & 5078 \\
\hline $\mathrm{F} 4$ & 830 & 2 & 1 & 129 & 1690 & 0 & 1819 \\
\hline $\mathrm{F} 4$ & 830 & 3 & 1 & 1524 & 13999 & 4649 & 20173 \\
\hline F4 & 831 & 1 & 1 & 1329 & 16813 & 14538 & 32680 \\
\hline F4 & 831 & 2 & 1 & 187 & 6273 & 2861 & 9321 \\
\hline F4 & 831 & 3 & 1 & 571 & 11070 & 4610 & 16252 \\
\hline $\mathrm{F} 4$ & 832 & 1 & 1 & 1204 & 10308 & 13168 & 24679 \\
\hline F4 & 832 & 2 & 1 & 645 & 12255 & 8619 & 21520 \\
\hline
\end{tabular}


ANEXO B - Dados de nordiidrocapsaicina (Nordiidro), capsaicina, diidrocapsaicina (Diidro) e capsaicinóides totais (Caps. Totais) em SHU nos três blocos para as gerações $\mathrm{P}_{1}, \mathrm{P}_{2}, \mathrm{~F}_{1}$, $\mathrm{F}_{4}$ e $\mathrm{RC}_{11 .}$ Capsicum annuum L. 2002.

\begin{tabular}{|c|c|c|c|c|c|c|c|}
\hline Geração & Genótipo & Bloco & Parcela & Nordiidro & Capsaicina & Diidro & Caps. Totais \\
\hline F4 & 832 & 3 & 1 & 503 & 6817 & 4214 & 11535 \\
\hline F4 & 833 & 1 & 1 & 1482 & 7527 & 10638 & 19647 \\
\hline F4 & 833 & 2 & 1 & 1223 & 7800 & 6937 & 15961 \\
\hline F4 & 833 & 3 & 1 & & & & \\
\hline F4 & 835 & 1 & 1 & 1435 & 22280 & 20548 & 44263 \\
\hline F4 & 835 & 2 & 1 & 692 & 22947 & 10770 & 34408 \\
\hline F4 & 835 & 3 & 1 & 703 & 22047 & 10857 & 33607 \\
\hline $\mathrm{F} 4$ & 836 & 1 & 1 & 0 & 1315 & 3204 & 4519 \\
\hline F4 & 836 & 2 & 1 & 112 & 1276 & 730 & 2118 \\
\hline F4 & 836 & 3 & 1 & 0 & 837 & 417 & 1254 \\
\hline F4 & 839 & 1 & 1 & 102 & 2909 & 1230 & 4241 \\
\hline F4 & 839 & 2 & 1 & 0 & 2833 & 1448 & 4281 \\
\hline F4 & 839 & 3 & 1 & 0 & 0 & 0 & 0 \\
\hline F4 & 840 & 1 & 1 & 0 & 0 & 0 & 0 \\
\hline F4 & 840 & 2 & 1 & 0 & 0 & 0 & 0 \\
\hline F4 & 840 & 3 & 1 & 0 & 0 & 0 & 0 \\
\hline $\mathrm{F} 4$ & 842 & 1 & 1 & 0 & 0 & 0 & 0 \\
\hline F4 & 842 & 2 & 1 & 0 & 0 & 0 & 0 \\
\hline F4 & 842 & 3 & 1 & 0 & 0 & 0 & 0 \\
\hline $\mathrm{F} 4$ & 843 & 1 & 1 & 1600 & 18305 & 16699 & 36604 \\
\hline F4 & 843 & 2 & 1 & 875 & 14512 & 9235 & 24622 \\
\hline $\mathrm{F} 4$ & 843 & 3 & 1 & 1402 & 20941 & 13315 & 35658 \\
\hline F4 & 844 & 1 & 1 & 380 & 14187 & 3826 & 18393 \\
\hline F4 & 844 & 2 & 1 & 367 & 14851 & 4704 & 19922 \\
\hline F4 & 844 & 3 & 1 & 390 & 16086 & 4148 & 20624 \\
\hline F4 & 845 & 1 & 1 & 159 & 4651 & 2320 & 7130 \\
\hline F4 & 845 & 2 & 1 & 178 & 3518 & 1025 & 4722 \\
\hline $\mathrm{F} 4$ & 845 & 3 & 1 & 0 & 2730 & 1377 & 4106 \\
\hline $\mathrm{F} 4$ & 846 & 1 & 1 & 62 & 704 & 629 & 1396 \\
\hline $\mathrm{F} 4$ & 846 & 2 & 1 & 0 & 625 & 0 & 625 \\
\hline F4 & 846 & 3 & 1 & 94 & 2549 & 1388 & 4031 \\
\hline F4 & 847 & 1 & 1 & 233 & 2145 & 1157 & 3535 \\
\hline F4 & 847 & 2 & 1 & 103 & 1721 & 555 & 2380 \\
\hline $\mathrm{F} 4$ & 847 & 3 & 1 & 0 & 1363 & 408 & 1772 \\
\hline F4 & 848 & 1 & 1 & 0 & 0 & 0 & 0 \\
\hline F4 & 848 & 2 & 1 & 0 & 0 & 0 & 0 \\
\hline F4 & 848 & 3 & 1 & 0 & 0 & 0 & 0 \\
\hline $\mathrm{F} 4$ & 849 & 1 & 1 & 392 & 5581 & 3014 & 8986 \\
\hline $\mathrm{F} 4$ & 849 & 2 & 1 & 243 & 5062 & 2117 & 7422 \\
\hline F4 & 849 & 3 & 1 & 223 & 5816 & 1686 & 7725 \\
\hline F4 & 850 & 1 & 1 & 675 & 17559 & 10336 & 28569 \\
\hline $\mathrm{F} 4$ & 850 & 2 & 1 & 67 & 10110 & 4341 & 14518 \\
\hline F4 & 850 & 3 & 1 & 1224 & 11717 & 3372 & 16313 \\
\hline F4 & 851 & 1 & 1 & 0 & 0 & 0 & 0 \\
\hline
\end{tabular}


ANEXO B - Dados de nordiidrocapsaicina (Nordiidro), capsaicina, diidrocapsaicina (Diidro) e capsaicinóides totais (Caps. Totais) em SHU nos três blocos para as gerações $\mathrm{P}_{1}, \mathrm{P}_{2}, \mathrm{~F}_{1}$, $\mathrm{F}_{4}$ e $\mathrm{RC}_{11 .}$ Capsicum annuum L. 2002.

\begin{tabular}{|c|c|c|c|c|c|c|c|}
\hline Geração & Genótipo & Bloco & Parcela & Nordiidro & Capsaicina & Diidro & Caps. Totais \\
\hline $\mathrm{F} 4$ & 851 & 2 & 1 & 0 & 0 & 0 & 0 \\
\hline F4 & 851 & 3 & 1 & 0 & 0 & 0 & 0 \\
\hline F4 & 852 & 1 & 1 & 720 & 12225 & 8421 & 21366 \\
\hline F4 & 852 & 2 & 1 & 1162 & 34223 & 13784 & 49169 \\
\hline F4 & 852 & 3 & 1 & 595 & 18137 & 8453 & 27185 \\
\hline F4 & 853 & 1 & 1 & 0 & 0 & 0 & 0 \\
\hline F4 & 853 & 2 & 1 & 0 & 0 & 0 & 0 \\
\hline F4 & 853 & 3 & 1 & 0 & 0 & 0 & 0 \\
\hline F4 & 855 & 1 & 1 & 0 & 0 & 0 & 0 \\
\hline F4 & 855 & 2 & 1 & 0 & 0 & 0 & 0 \\
\hline F4 & 855 & 3 & 1 & 0 & 0 & 0 & 0 \\
\hline F4 & 856 & 1 & 1 & 0 & 0 & 0 & 0 \\
\hline $\mathrm{F} 4$ & 856 & 2 & 1 & 0 & 0 & 0 & 0 \\
\hline F4 & 856 & 3 & 1 & & & & \\
\hline F4 & 857 & 1 & 1 & 0 & 0 & 0 & 0 \\
\hline F4 & 857 & 2 & 1 & 0 & 0 & 0 & 0 \\
\hline $\mathrm{F} 4$ & 857 & 3 & 1 & 0 & 0 & 0 & 0 \\
\hline F4 & 858 & 1 & 1 & 191 & 2759 & 2274 & 5224 \\
\hline F4 & 858 & 2 & 1 & 0 & 0 & 0 & 0 \\
\hline F4 & 858 & 3 & 1 & 0 & 0 & 0 & 0 \\
\hline F4 & 859 & 1 & 1 & 0 & 0 & 0 & 0 \\
\hline $\mathrm{F} 4$ & 859 & 2 & 1 & 0 & 0 & 0 & 0 \\
\hline F4 & 859 & 3 & 1 & 0 & 0 & 0 & 0 \\
\hline F4 & 862 & 1 & 1 & 0 & 0 & 0 & 0 \\
\hline F4 & 862 & 2 & 1 & 0 & 0 & 0 & 0 \\
\hline F4 & 862 & 3 & 1 & 0 & 2693 & 0 & 2693 \\
\hline F4 & 863 & 1 & 1 & 635 & 8190 & 5825 & 14651 \\
\hline F4 & 863 & 2 & 1 & 314 & 11632 & 7843 & 19790 \\
\hline F4 & 863 & 3 & 1 & 572 & 12159 & 8909 & 21641 \\
\hline F4 & 864 & 1 & 1 & 0 & 0 & 0 & 0 \\
\hline F4 & 864 & 2 & 1 & 0 & 0 & 0 & 0 \\
\hline F4 & 864 & 3 & 1 & 0 & 0 & 0 & 0 \\
\hline F4 & 865 & 1 & 1 & 2389 & 44243 & 30794 & 77426 \\
\hline $\mathrm{F} 4$ & 865 & 2 & 1 & 606 & 17647 & 6682 & 24935 \\
\hline F4 & 865 & 3 & 1 & 1256 & 27266 & 8119 & 36640 \\
\hline F4 & 866 & 1 & 1 & 0 & 0 & 0 & 0 \\
\hline F4 & 866 & 2 & 1 & 0 & 0 & 0 & 0 \\
\hline $\mathrm{F} 4$ & 866 & 3 & 1 & 0 & 0 & 0 & 0 \\
\hline $\mathrm{F} 4$ & 867 & 1 & 1 & 1567 & 10510 & 14169 & 26246 \\
\hline F4 & 867 & 2 & 1 & 1184 & 6700 & 9695 & 17579 \\
\hline F4 & 867 & 3 & 1 & 5940 & 53270 & 52973 & 112183 \\
\hline $\mathrm{F} 4$ & 868 & 1 & 1 & 2141 & 26696 & 22607 & 51443 \\
\hline $\mathrm{F} 4$ & 868 & 2 & 1 & 1581 & 35412 & 21237 & 58230 \\
\hline F4 & 868 & 3 & 1 & 1857 & 36623 & 22314 & 60795 \\
\hline
\end{tabular}


ANEXO B - Dados de nordiidrocapsaicina (Nordiidro), capsaicina, diidrocapsaicina (Diidro) e capsaicinóides totais (Caps. Totais) em SHU nos três blocos para as gerações $\mathrm{P}_{1}, \mathrm{P}_{2}, \mathrm{~F}_{1}, \mathrm{~F}_{4}$ e $\mathrm{RC}_{11}$. Capsicum annuum L. 2002.

\begin{tabular}{|c|c|c|c|c|c|c|c|}
\hline Geração & Genótipo & Bloco & Parcela & Nordiidro & Capsaicina & Diidro & Caps. Totais \\
\hline F4 & 869 & 1 & 1 & 1020 & 7279 & 8097 & 16397 \\
\hline F4 & 869 & 2 & 1 & 1234 & 11483 & 12672 & 25389 \\
\hline F4 & 869 & 3 & 1 & & & & \\
\hline F4 & 870 & 1 & 1 & 0 & 0 & 0 & 0 \\
\hline F4 & 870 & 2 & 1 & 0 & 0 & 0 & 0 \\
\hline F4 & 870 & 3 & 1 & 0 & 0 & 0 & 0 \\
\hline $\mathrm{F} 4$ & 871 & 1 & 1 & 1007 & 12709 & 11000 & 24716 \\
\hline F4 & 871 & 2 & 1 & 478 & 6801 & 5360 & 12639 \\
\hline F4 & 871 & 3 & 1 & 993 & 11566 & 12407 & 24967 \\
\hline F4 & 872 & 1 & 1 & 1933 & 19215 & 16522 & 37670 \\
\hline $\mathrm{F} 4$ & 872 & 2 & 1 & 967 & 14969 & 9657 & 25593 \\
\hline F4 & 873 & 1 & 1 & 0 & 0 & 0 & 0 \\
\hline F4 & 873 & 2 & 1 & 0 & 0 & 0 & 0 \\
\hline F4 & 873 & 3 & 1 & 0 & 0 & 0 & 0 \\
\hline F4 & 874 & 1 & 1 & 1953 & 30608 & 21840 & 54401 \\
\hline F4 & 874 & 2 & 1 & 1922 & 34193 & 17146 & 53261 \\
\hline F4 & 874 & 3 & 1 & 933 & 25370 & 11321 & 37624 \\
\hline F4 & 875 & 1 & 1 & 0 & 0 & 0 & 0 \\
\hline F4 & 875 & 2 & 1 & 0 & 0 & 0 & 0 \\
\hline F4 & 875 & 3 & 1 & 0 & 0 & 0 & 0 \\
\hline F4 & 876 & 1 & 1 & 123 & 5820 & 2445 & 8388 \\
\hline F4 & 876 & 2 & 1 & 0 & 1154 & 0 & 1154 \\
\hline F4 & 876 & 3 & 1 & 0 & 1841 & 417 & 2258 \\
\hline $\mathrm{F} 4$ & 877 & 1 & 1 & 499 & 15540 & 8947 & 24986 \\
\hline F4 & 877 & 2 & 1 & 220 & 8385 & 3640 & 12246 \\
\hline F4 & 877 & 3 & 1 & 229 & 9213 & 5508 & 14950 \\
\hline F4 & 878 & 1 & 1 & 0 & 0 & 0 & 0 \\
\hline $\mathrm{F} 4$ & 878 & 2 & 1 & 0 & 0 & 0 & 0 \\
\hline F4 & 878 & 3 & 1 & 0 & 0 & 0 & 0 \\
\hline F4 & 879 & 1 & 1 & & & & \\
\hline F4 & 879 & 2 & 1 & 0 & 3686 & 1320 & 5006 \\
\hline F4 & 879 & 3 & 1 & 0 & 737 & 0 & 737 \\
\hline F4 & 880 & 1 & 1 & 0 & 0 & 0 & 0 \\
\hline F4 & 880 & 2 & 1 & 0 & 0 & 0 & 0 \\
\hline F4 & 880 & 3 & 1 & 0 & 0 & 0 & 0 \\
\hline F4 & 881 & 1 & 1 & 0 & 0 & 0 & 0 \\
\hline $\mathrm{F} 4$ & 881 & 2 & 1 & 0 & 0 & 0 & 0 \\
\hline F4 & 881 & 3 & 1 & 0 & 0 & 0 & 0 \\
\hline F4 & 882 & 1 & 1 & 0 & 0 & 0 & 0 \\
\hline F4 & 882 & 2 & 1 & 0 & 0 & 0 & 0 \\
\hline $\mathrm{F} 4$ & 882 & 3 & 1 & 0 & 0 & 0 & 0 \\
\hline F4 & 884 & 1 & 1 & 0 & 0 & 0 & 0 \\
\hline F4 & 884 & 2 & 1 & & & & \\
\hline F4 & 884 & 3 & 1 & 0 & 0 & 0 & 0 \\
\hline
\end{tabular}


ANEXO B - Dados de nordiidrocapsaicina (Nordiidro), capsaicina, diidrocapsaicina (Diidro) e capsaicinóides totais (Caps. Totais) em SHU nos três blocos para as gerações $\mathrm{P}_{1}, \mathrm{P}_{2}, \mathrm{~F}_{1}, \mathrm{~F}_{4}$ e $\mathrm{RC}_{11}$. Capsicum annuum L. 2002.

\begin{tabular}{lrrrrrrr}
\hline Geração & Genótipo & Bloco & \multicolumn{1}{r}{ Parcela } & Nordiidro & Capsaicina & Diidro & Caps. Totais \\
\hline F4 & 885 & 1 & 1 & 630 & 9695 & 6850 & 17175 \\
F4 & 885 & 2 & 1 & 255 & 3954 & 1312 & 5521 \\
F4 & 885 & 3 & 1 & 657 & 8884 & 7580 & 17121 \\
F4 & 886 & 1 & 1 & 0 & 0 & 0 & 0 \\
F4 & 886 & 2 & 1 & 0 & 0 & 0 & 0 \\
F4 & 886 & 3 & 1 & 0 & 0 & 0 & 0 \\
F4 & 887 & 1 & 1 & 1886 & 20759 & 16282 & 38927 \\
F4 & 887 & 2 & 1 & 1618 & 26472 & 19704 & 47794 \\
F4 & 887 & 3 & 1 & & & & \\
F4 & 888 & 1 & 1 & 0 & 0 & 0 & 0 \\
F4 & 888 & 2 & 1 & 0 & 0 & 0 & 0 \\
F4 & 888 & 3 & 1 & 0 & 0 & 0 & 0 \\
F4 & 889 & 1 & 1 & 0 & 0 & 0 & 0 \\
F4 & 889 & 2 & 1 & 0 & 0 & 0 & 0 \\
F4 & 889 & 3 & 1 & 0 & 0 & 0 & 0 \\
F4 & 890 & 1 & 1 & 1395 & 5625 & 8578 & 15598 \\
F4 & 890 & 2 & 1 & 837 & 5728 & 4233 & 10798 \\
F4 & 890 & 3 & 1 & 463 & 4189 & 3960 & 8611 \\
F4 & 891 & 1 & 1 & 0 & 0 & 0 & 0 \\
F4 & 891 & 2 & 1 & 852 & 13587 & 8386 & 22825 \\
F4 & 891 & 3 & 1 & 750 & 15953 & 9469 & 26173 \\
F4 & 892 & 1 & 1 & 0 & 0 & 0 & 0 \\
F4 & 892 & 2 & 1 & 0 & 0 & 0 & 0 \\
F4 & 892 & 3 & 1 & 0 & 0 & 0 & 0 \\
\hline & & & & & & &
\end{tabular}




\section{ANEXO C - Protocolo das análises de variância e obtenção das médias utilizados para todos os caracteres avaliados. Capsicum annuum L. 2002.}

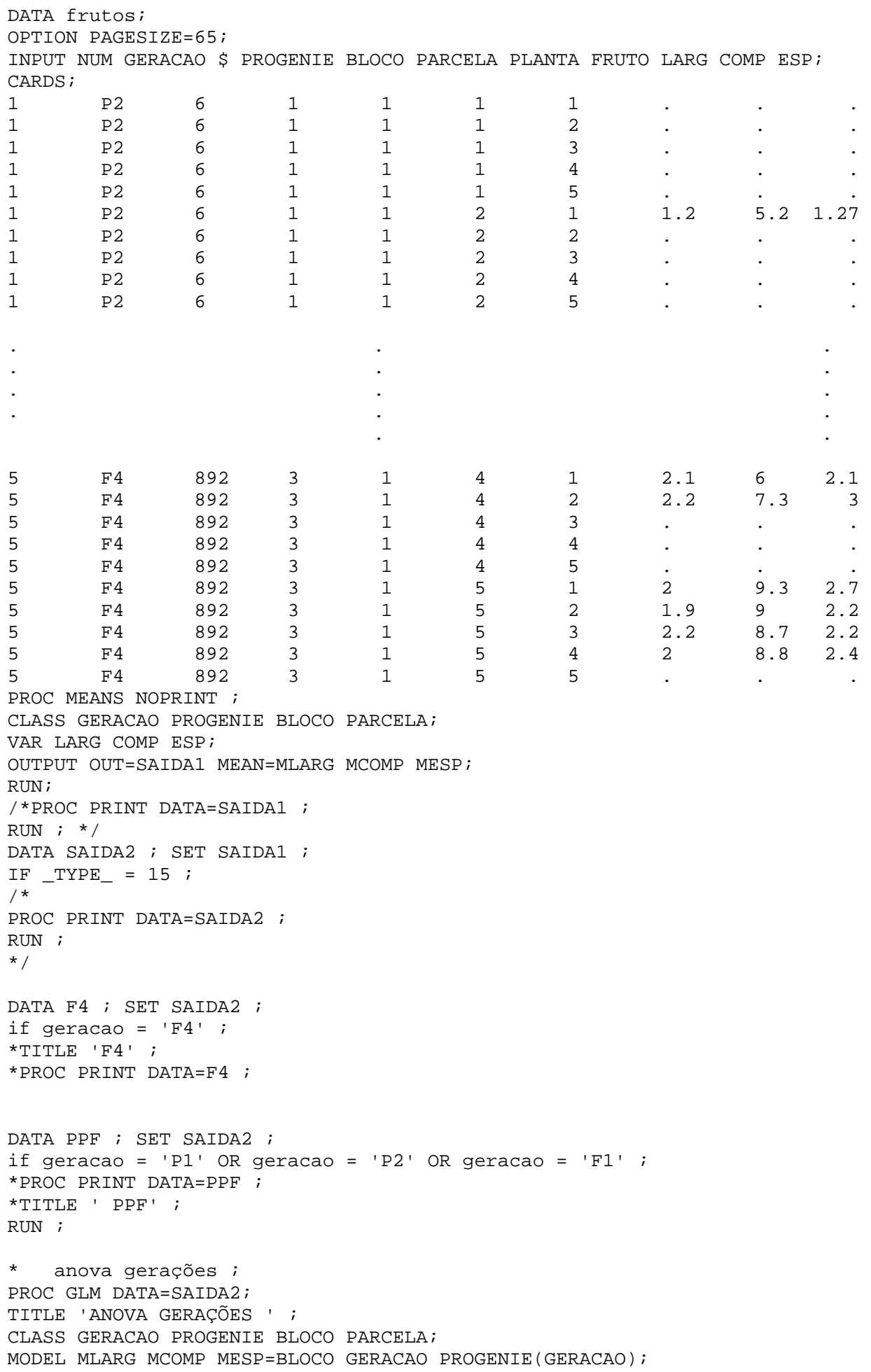


ANEXO C - Protocolo das análises de variância e obtenção das médias utilizados para todos os caracteres avaliados. Capsicum annuum L. 2002.

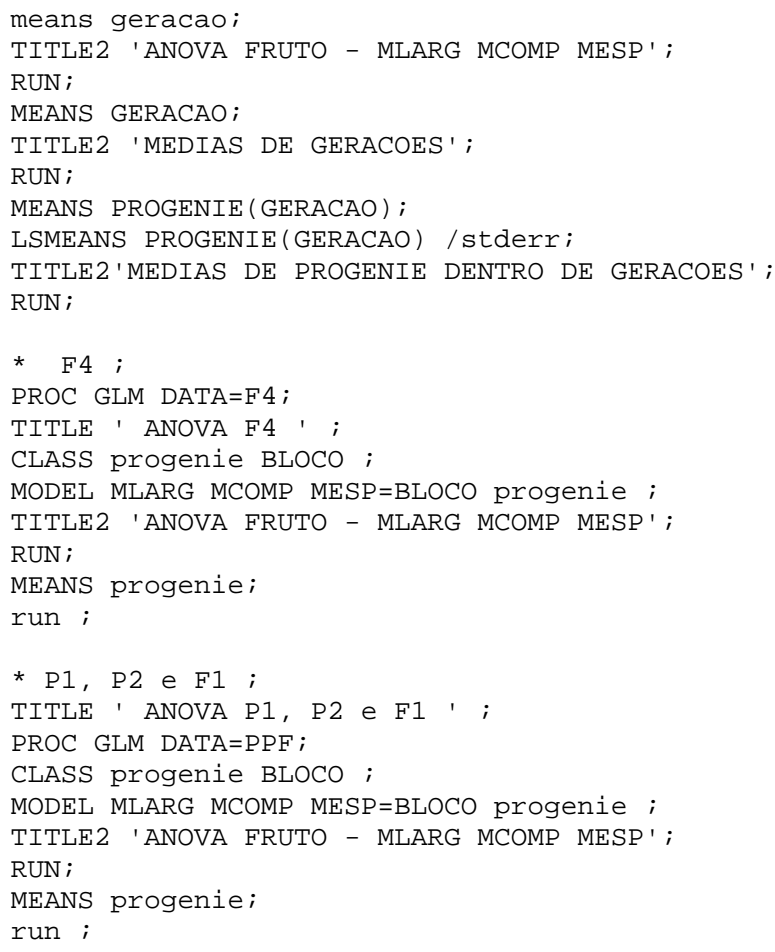


ANEXO D - Respostas correlacionadas a seleção (RCs) para aumento da pungência. Capsicum anпиит L. 2002.

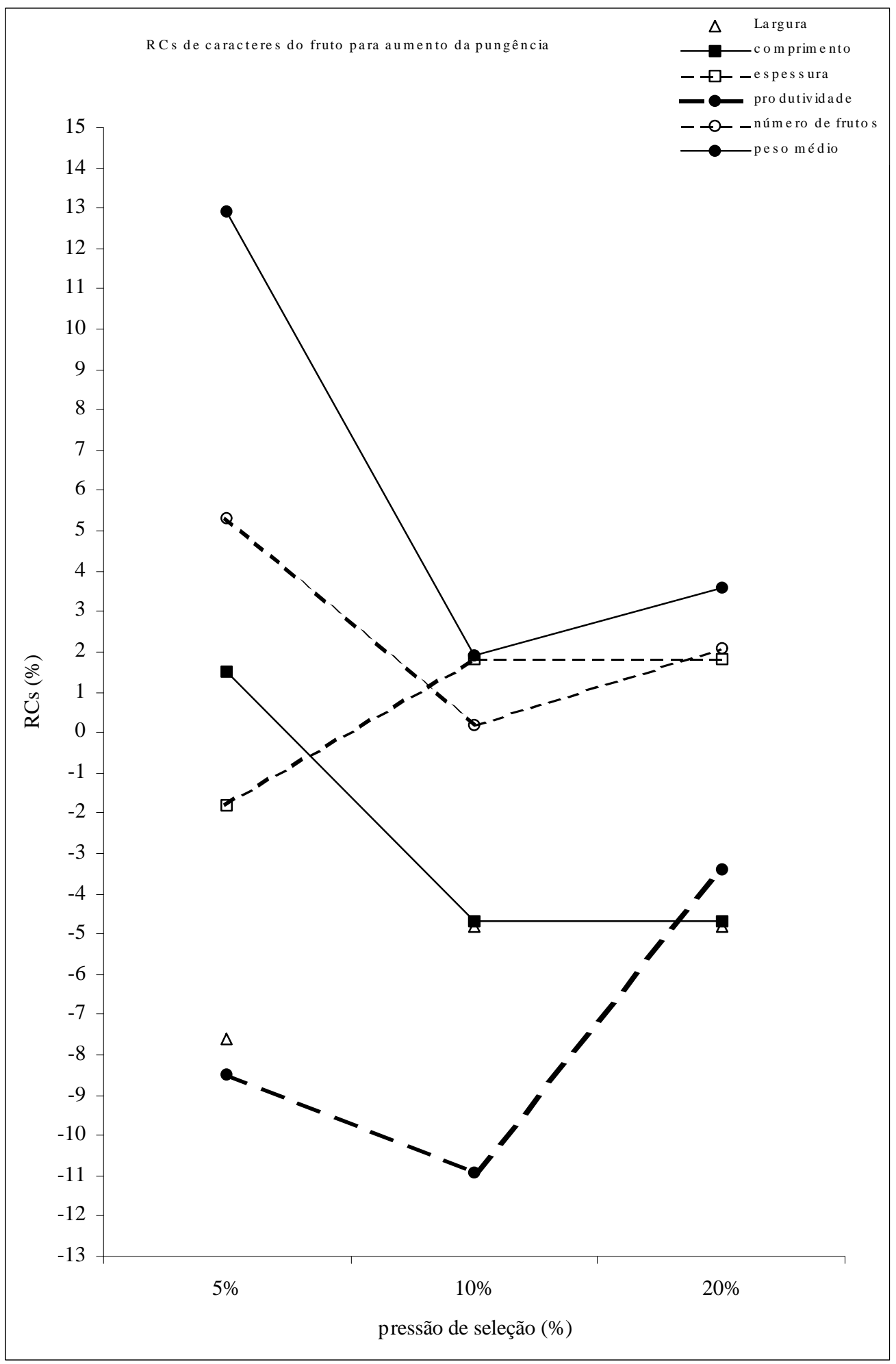


ANEXO E - Respostas correlacionadas a seleção (RCs) para diminuição da pungência. Capsicum anпиum L. 2002.

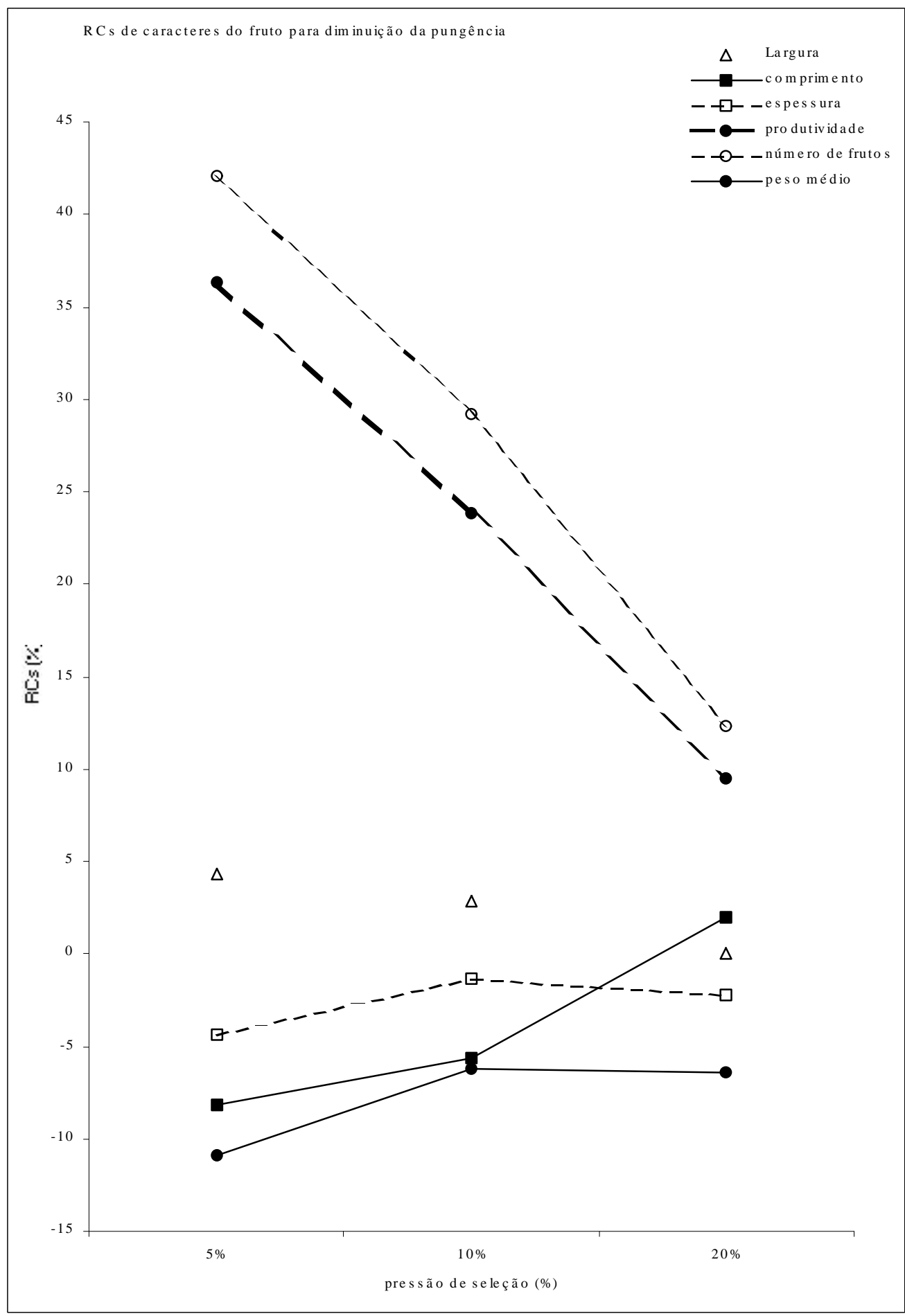


ANEXO F - Médias observadas nos três blocos, das progênies $F_{4,3}$ dos dados de largura e comprimento do fruto, espessura da polpa, produtividade, número e peso médio dos frutos. Capsicum annuum L. 2002.

\begin{tabular}{|c|c|c|c|c|c|c|}
\hline Progênies $F_{4,3}$ & Largura $(\mathrm{cm})$ & Comprimento $(\mathrm{cm})$ & Espessura (mm) & Produtividade (g) & Número & Peso (g) \\
\hline 766 & 1,92 & 5,61 & 2,04 & 81,79 & 14,13 & 5,95 \\
\hline 769 & 2,28 & 7,13 & 2,03 & 93,02 & 12,10 & 9,51 \\
\hline 771 & 1,73 & 6,40 & 2,21 & 185,67 & 34,90 & 5,81 \\
\hline 773 & 2,07 & 5,90 & 2,51 & 84,77 & 9,92 & 9,11 \\
\hline 774 & 1,84 & 5,52 & 2,38 & 56,23 & 8,93 & 6,30 \\
\hline 775 & 2,42 & 9,77 & 2,13 & 148,66 & 12,00 & 13,76 \\
\hline 776 & 1,80 & 7,58 & 2,12 & 51,24 & 6,00 & 7,89 \\
\hline 777 & 2,47 & 8,05 & 2,24 & 109,39 & 10,00 & 12,23 \\
\hline 779 & 2,14 & 5,98 & 2,17 & 173,96 & 22,50 & 7,68 \\
\hline 780 & 2,23 & 7,21 & 2,20 & 151,95 & 17,27 & 9,52 \\
\hline 781 & 2,35 & 6,58 & 2,24 & 240,87 & 27,73 & 8,42 \\
\hline 782 & 2,10 & 7,49 & 2,09 & 94,15 & 12,87 & 7,61 \\
\hline 783 & 1,80 & 5,67 & 2,56 & 136,86 & 23,87 & 5,89 \\
\hline 784 & 1,71 & 7,00 & 1,90 & 135,18 & 31,80 & 5,66 \\
\hline 785 & 1,73 & 8,23 & 2,25 & 87,23 & 10,40 & 8,55 \\
\hline 786 & 1,99 & 6,74 & 2,03 & 67,80 & 5,40 & 10,11 \\
\hline 787 & 2,04 & 7,48 & 2,03 & 90,58 & 15,40 & 5,33 \\
\hline 789 & 2,22 & 7,58 & 2,46 & 208,47 & 23,27 & 9,82 \\
\hline 790 & 1,72 & 5,33 & 1,80 & 137,40 & 25,64 & 6,01 \\
\hline 791 & 2,08 & 7,50 & 2,09 & 61,81 & 8,78 & 7,42 \\
\hline 792 & 2,19 & 6,21 & 1,96 & 72,12 & 13,80 & 5,58 \\
\hline 795 & 1,72 & 4,26 & 2,03 & 62,46 & 21,10 & 3,88 \\
\hline 796 & 2,19 & 7,23 & 2,34 & 217,11 & 26,50 & 7,90 \\
\hline 797 & 2,06 & 4,73 & 1,81 & 236,57 & 44,33 & 5,28 \\
\hline 799 & 2,14 & 9,43 & 2,57 & 110,24 & 13,56 & 11,04 \\
\hline 800 & 1,86 & 7,74 & 2,30 & 101,81 & 13,40 & 7,57 \\
\hline 802 & 2,29 & 7,65 & 2,33 & 126,39 & 14,40 & 10,15 \\
\hline 803 & 1,83 & 4,92 & 2,19 & 83,94 & 15,47 & 5,41 \\
\hline 804 & 2,16 & 6,55 & 2,00 & 220,18 & 28,93 & 8,14 \\
\hline 806 & 2,44 & 6,89 & 2,63 & 185,00 & 15,40 & 11,91 \\
\hline 807 & 2,08 & 6,21 & 2,12 & 144,09 & 15,87 & 8,80 \\
\hline 808 & 2,20 & 7,19 & 2,06 & 192,47 & 23,07 & 8,58 \\
\hline 809 & 1,85 & 4,35 & 2,39 & 131,01 & 26,50 & 4,94 \\
\hline 810 & 2,26 & 9,32 & 2,33 & 83,67 & 6,67 & 12,59 \\
\hline 811 & 2,22 & 6,05 & 2,23 & 88,64 & 11,00 & 8,12 \\
\hline 813 & 1,55 & 5,03 & 1,99 & 59,82 & 15,11 & 4,02 \\
\hline 817 & 2,04 & 5,14 & 1,89 & 83,93 & 22,90 & 4,83 \\
\hline 819 & 2,06 & 5,36 & 2,09 & 50,24 & 11,90 & 5,77 \\
\hline 821 & 1,96 & 4,97 & 2,10 & 248,87 & 49,80 & 5,34 \\
\hline 822 & 1,97 & 7,74 & 2,17 & 154,24 & 29,11 & 6,64 \\
\hline 823 & 1,88 & 6,75 & 2,24 & 28,02 & 5,83 & 6,42 \\
\hline 824 & 1,91 & 5,96 & 2,09 & 59,19 & 9,67 & 6,91 \\
\hline 825 & 2,04 & 7,23 & 2,28 & 192,99 & 21,93 & 8,65 \\
\hline
\end{tabular}


ANEXO F - Médias observadas nos três blocos das progênies $\mathrm{F}_{4,3}$ dos dados de largura e comprimento do fruto espessura da polpa produtividade número e peso médio dos frutos. Capsicum annuum L. 2002.

\begin{tabular}{|c|c|c|c|c|c|c|}
\hline Progênies $F_{4,3}$ & Largura (cm) & Comprimento $(\mathrm{cm})$ & Espessura (mm) & Produtividade (g) & Número & Peso (g) \\
\hline 826 & 1,76 & 6,50 & 1,94 & 41,69 & 5,23 & 5,85 \\
\hline 827 & 2,42 & 8,00 & 2,26 & 132,70 & 12,80 & 10,58 \\
\hline 828 & 1,74 & 4,23 & 1,61 & 29,43 & 6,93 & 4,09 \\
\hline 829 & 2,44 & 6,90 & 2,25 & 119,34 & 12,47 & 9,55 \\
\hline 830 & 1,97 & 5,63 & 1,80 & 59,22 & 10,00 & 5,20 \\
\hline 831 & 2,63 & 4,81 & 3,04 & 58,53 & 5,77 & 11,10 \\
\hline 832 & 1,92 & 0,60 & 2,02 & 78,66 & 12,80 & 9,06 \\
\hline 833 & 2,44 & 9,26 & 2,29 & 87,94 & 7,30 & 11,92 \\
\hline 835 & 2,16 & 6,38 & 2,39 & 111,78 & 12,47 & 9,11 \\
\hline 836 & 1,61 & 6,27 & 2,20 & 46,73 & 21,14 & 5,32 \\
\hline 839 & 2,32 & 7,00 & 2,54 & 53,04 & 4,44 & 12,97 \\
\hline 840 & 1,95 & 6,74 & 2,25 & 29,56 & 5,30 & 7,50 \\
\hline 842 & 1,85 & 7,81 & 1,89 & 53,72 & 11,00 & 5,68 \\
\hline 843 & 2,01 & 9,14 & 2,71 & 131,79 & 11,33 & 12,67 \\
\hline 844 & 2,32 & 6,76 & 2,41 & 105,53 & 11,60 & 9,25 \\
\hline 845 & 2,41 & 7,97 & 2,18 & 141,15 & 21,00 & 7,98 \\
\hline 846 & 2,79 & 8,67 & 2,41 & 168,33 & 14,90 & 15,67 \\
\hline 847 & 2,40 & 6,27 & 2,23 & 210,52 & 28,90 & 7,90 \\
\hline 848 & 2,01 & 7,33 & 2,30 & 181,27 & 19,60 & 9,38 \\
\hline 849 & 1,79 & 5,99 & 2,19 & 113,52 & 19,53 & 5,42 \\
\hline 850 & 2,11 & 8,28 & 2,52 & 109,58 & 10,20 & 10,26 \\
\hline 851 & 1,89 & 6,94 & 1,98 & 229,72 & 46,70 & 5,79 \\
\hline 852 & 2,01 & 8,07 & 2,16 & 192,38 & 24,00 & 8,54 \\
\hline 853 & 2,14 & 7,46 & 2,52 & 118,60 & 12,27 & 9,91 \\
\hline 855 & 2,23 & 6,59 & 2,41 & 125,24 & 14,47 & 8,37 \\
\hline 856 & 2,43 & 5,89 & 2,72 & 102,75 & 15,00 & 7,50 \\
\hline 857 & 2,15 & 6,13 & 2,01 & 180,37 & 21,79 & 7,51 \\
\hline 858 & 2,13 & 6,37 & 2,19 & 73,94 & 9,40 & 8,19 \\
\hline 859 & 2,54 & 7,60 & 2,48 & 253,23 & 21,47 & 12,05 \\
\hline 862 & 2,12 & 6,88 & 2,72 & 183,75 & 19,13 & 9,74 \\
\hline 863 & 2,44 & 5,80 & 3,02 & 137,65 & 15,00 & 9,17 \\
\hline 864 & 2,13 & 5,47 & 2,00 & 111,56 & 15,67 & 6,43 \\
\hline 865 & 2,58 & 5,48 & 3,30 & 158,12 & 15,70 & 10,84 \\
\hline 866 & 1,51 & 5,03 & 2,15 & 111,77 & 35,90 & 4,25 \\
\hline 867 & 2,10 & 5,62 & 2,55 & 93,95 & 17,10 & 7,33 \\
\hline 868 & 1,80 & 8,94 & 2,33 & 125,35 & 14,80 & 21,33 \\
\hline 869 & 2,42 & 7,22 & 2,53 & 84,12 & 6,93 & 12,25 \\
\hline 870 & 2,16 & 6,16 & 2,20 & 53,60 & 8,21 & 6,63 \\
\hline 871 & 2,06 & 9,41 & 2,22 & 120,87 & 12,20 & 9,88 \\
\hline 872 & 2,12 & 6,11 & 2,16 & 58,75 & 7,90 & 7,97 \\
\hline 873 & 2,01 & 8,75 & 2,26 & 231,35 & 24,60 & 10,18 \\
\hline 874 & 1,82 & 6,08 & 2,00 & 84,35 & 29,00 & 4,84 \\
\hline 875 & 2,62 & 0,35 & 2,70 & 208,29 & 11,27 & 18,31 \\
\hline 876 & 2,19 & 5,32 & 2,66 & 71,13 & 14,38 & 7,61 \\
\hline 877 & 2,10 & 6,20 & 2,35 & 145,65 & 16,71 & 8,80 \\
\hline
\end{tabular}


ANEXO F - Médias observadas nos três blocos das progênies $\mathrm{F}_{4,3}$ dos dados de largura e comprimento do fruto espessura da polpa produtividade número e peso médio dos frutos. Capsicum annuum L. 2002.

$\begin{array}{ccccrrr}\text { Progênies } \mathrm{F}_{4,3} & \text { Largura }(\mathrm{cm}) & \text { Comprimento }(\mathrm{cm}) & \text { Espessura }(\mathrm{mm}) & \text { Produtividade }(\mathrm{g}) & \text { Número } & \text { Peso }(\mathrm{g}) \\ 878 & 2,23 & 7,88 & 2,33 & 182,10 & 20,91 & 8,52 \\ 879 & 2,41 & 6,33 & 2,23 & 79,80 & 9,13 & 8,94 \\ 880 & 2,19 & 7,13 & 2,17 & 141,97 & 13,67 & 9,82 \\ 881 & 1,96 & 5,42 & 2,03 & 132,12 & 25,00 & 5,54 \\ 882 & 2,92 & 7,93 & 2,57 & 79,59 & 5,50 & 14,80 \\ 884 & 1,89 & 6,98 & 2,08 & 108,55 & 17,40 & 6,24 \\ 885 & 2,11 & 5,98 & 2,40 & 155,25 & 18,50 & 7,82 \\ 886 & 2,58 & 7,04 & 2,12 & 293,08 & 31,33 & 10,31 \\ 887 & 1,80 & 4,35 & 2,06 & 22,98 & 6,40 & 4,80 \\ 888 & 2,02 & 7,34 & 2,14 & 73,61 & 19,60 & 7,17 \\ 889 & 1,88 & 6,60 & 2,23 & 131,59 & 20,57 & 6,80 \\ 890 & 1,77 & 9,37 & 2,00 & 117,27 & 15,00 & 7,70 \\ 891 & 1,73 & 5,58 & 2,41 & 47,46 & 8,67 & 5,50 \\ 892 & 2,00 & 9,12 & 2,30 & 86,43 & 9,13 & 9,51 \\ \mathrm{~s}(\overline{\mathrm{Y}})_{\mathrm{F} 4}= & 008 & 038 & 012 & 3388 & 444 & 244 \\ \mathrm{~s}(\overline{\mathrm{Y}})_{\mathrm{Pl} \mathrm{P} 2 \mathrm{~F} 1}= & 008 & 026 & 016 & 2879 & 280 & 132 \\ \mathrm{~s}(\overline{\mathrm{Y}})_{\mathrm{RC} 11}= & 009 & 037 & 012 & 3475 & 454 & 145\end{array}$




\section{REFERÊNCIAS BIBLIOGRÁFICAS}

AMERICAN SPICE TRADE ASSOCIATION. Official analytical methods of the American Spice Trade Association. 3.ed. Englewood Cliffs: American Spice Trade Association, 1985. 54p.

ATTUQUAYEFIO, V.K.; BUCKLE, K.A. Rapid sample preparation method for HPLC analysis of Capsicum fruits and oleoresins. Journal of Agricultural Food Chemistry, v.35, p.777-779, 1987.

BARBIN, D. Componentes de variância: teoria a aplicações. 2.ed. Piracicaba: Fealq, 1998. 120p.

BERNAL, M.A.; CALDERÓN, A.A.; PEDREÑO, M.A.; MUÑOZ, R.; BARCELÓ, A.R.; CÁCERES, F.M. Capsaicin oxidation by peroxidase from Capsicum annuum (var. annuum) fruits. Journal of Agricultural and Food Chemistry, v.41, p.1041-1044, July 1993.

BERNAL, M.A.; CALDERÓN, A.A.; FERRER, M.A.; CÁCERES, F.M.; BARCELÓ, A.R. Oxidation of capsaicin and capsaicin phenolic precursors by the basic peroxidase isoenzyme $\mathrm{B}_{6}$ from hot pepper. Journal of Agricultural and Food Chemistry, v.43, p.352-355, 1995. 
BERNAL, M.A.; BARCELÓ, A.R. 5,5'-Dicapsaicin, 4'-O-5-Dicapsaicin ether, and dehydrogenation polymers with high molecular weights are the main products of the oxidation of capsaicin by peroxidase from hot pepper. Journal of Agricultural and Food Chemistry, v.44, p.3085-3089, Oct. 1996.

BIANCHETTI, L.B. Aspectos morfológicos, ecológicos e biogeográficos de dez táxons de Capsicum (Solanaceae) ocorrentes no Brasil. Brasília, 1996. 174p. Dissertação (M.S.) - Universidade de Brasília.

BOSLAND, P.W. Breeding for quality in Capsicum. Capsicum and Eggplant Newsletter, v.12, p.25-31, 1993.

CHAIM, A.B.; PARAN, I.; GRUBE, R.C.; JAHN, M. Qtl mapping of fruit related traits in pepper (Capsicum апnиum). Theoretical Applied in Genetic, v.102, n.6-7, p.1016-1028, May 2001.

CHIANG, H.G. HPLC analysis of capsaicins and simultaneous determination of capsaicins and piperine by HPLC-ECD and UV. Journal of Food Science, v.51, n.2, p.499-503, 1986.

COLLINS, M.D.; BOSLAND, P.W. Rare and novel capsaicinoid profiles in Capsicum. Capsicum and Eggplant Newsletter, v.13, p.48-51, 1994.

COLLINS, M.D.; WASMUND, L.M.; BOSLAND, P.W. Improved method for quantifying capsaicinoids in Capsicum using high-performance liquid chromatography. HortScience, v.30, n.1, p.137-139, Feb. 1995.

COOPER, T.H.; GUZINSKI, J.A.; FISHER, C. Improved high-performance liquid chromatography method for determination of major capsaicinoids in capsicum oleoresins. Journal of Agricultural Food Chemistry, v.39, p.2253-2256, 1991. 
CRUZ, C.D.; REGAZZI, A.J. Modelos biométricos aplicados ao melhoramento genético. Viçosa: UFV, Imprensa Universitária, 1994. 390p.

CURRY, J.; ALURU, M.; MENDOZA, M.; NEVAREZ, J.; MELENDREZ, M.; O’CONNELL, M.A. Transcripts for possible capsaicinoid biosynthetic genes are differentially accumulated in pungent and non-pungent Capsicum spp. Plant Science, v.148, p.47-57, 1999.

DESHPANDE, R.B. Studies in indian chilles: (4) Inheritance of pungency in Capsicum annuит L. Indian Journal of Agricultural Science, v.5, p.513-516, June 1935.

DOSHI, K.M.; SHUKLA, P.T. Genetics of yield and its components in chilli (Capsicum annuит L.). Capsicum and Eggplant Newsletter, v.19, p.78-81, 2000.

EMBRAPA. www. cnph. embrapa.br / capscicum, 2003.

ESTRADA, B.; DIAZ, J.; MERINO, F.; BERNAL, M.A. The effect of seasonal changes on the pungency level of padron pepper fruits. Capsicum and Eggplant Newsletter, v.18, p.28-31, 1999a.

ESTRADA, B.; POMAR, F.; DIAZ, J.; MERINO, F.; BERNAL, M.A. Pungency level in fruits of the padrón pepper with different water supply. Scientia Horticulturae, v.81, p.385-396, 1999 b.

ESTRADA, B.; BERNAL, M.A.; DÍAZ, J.; POMAR, F.; MERINO, F. Fruit development in Capsicum annuиm: changes ic capsaicin, lignin, free phenolics, and peroxidase patterns. Journal of Agricultural and Food Chemistry, v.48, p.6234-6239, Nov. 2000. 
ESTRADA, B.; BERNAL, M.A.; DÍAZ, J.; POMAR, F.; MERINO, F. Capsaicinoids in vegetative organs of Capsicum annuиm L. in relation to fruiting. Journal of Agricultural and Food Chemistry, v.50, p.1188-1191, Feb. 2002.

FERREIRA, R.P.; SEDIYAMA, C.S.; CRUZ, C.D.; FREIRE, M.S. Herança da tolerância à toxidez de alumínio em arroz baseada em análise de médias e varâncias. Pesquisa Agropecuária Brasileira, v.32, n.5, p.509-515, maio 1997.

GALLEGO, F.J.; BENITO, C. Genetic control of aluminium tolerance in rye (Sacale cereale L.). Theoretical and Applied Genetics, v.95, n.3, p.393-399, Aug. 1997.

GREENLEAF, W.H. Pepper breeding. In: BASSETT, M.J. (Ed.). Breeding vegetable crops. Connecticut: AVI Publishing Company, 1986. cap.3, p.67-134.

HOFFMAN, P.G.; LEGO, M.C.; GALETTO, W.G. Separation and quantitative of red pepper major heat principles by reverse-phase high pressure liquid chromatography. Journal of Agricultural Food Chemistry, v.31, p.1326-1330, 1983.

INTERNATIONAL PLANT GENETIC RESOUCES INSTITUTE - IPGRI; ASIAN VEGETABLE RESEARCH AND DEVELOPMENT CENTER - AVRCC; CENTRO AGRONÓMICO TROPICAL DE INVESTIGACIÓN Y ENSEÑANZA - CATIE. Descriptors for Capsicum (Capsicum spp.). Rome: International Plant Genetic Resources Institute, 1995. 49p.

ISHIKAWA, K.; JANOS, T.; SAKAMOTO, S.; NUNOMURA, O. The contents of capsaicinoids and their phenolic intermediates in the various tissues of the plants of Capsicum апnиит L. Capsicum and Eggplant Newsletter, v.17, p.22-25, 1998. 
JOHNSON, T.S.; RAVISHANKAR, G.A.; VENKATARAMAN, L.V. Separation of capsaicin from phenylpropanoid compounds by high performance liquid chromatography to determine the biosynthetic status of cells and tissues of Capsicum frutescens Mill. in vivo and in vitro. Journal of Agricultural and Food Chemistry, v.40, p.2461-2463, Dec. 1992.

JOHNSON, T.S.; RAVISHANKAR, G.A. Precursor biotransformation in immobilized placental tissues of Capsicum frutescens Mill.: II. Influence of feeding intermediates of the capsaicinoid pathway in combination with L-valine on capsaicin and dihydrocapsaicin accumulation. Journal of Plant Physiology, v.153, p.240-243, 1998.

KIRSCHBAUM-TITZE, P.; HIEPLER, C.; MUELLER-SEITZ, E.; PETZ, M. Pungency in paprica (Capsicum anпиит). 1. Decrease of capsaicinoid content following cellular disruption. Journal of Agricultural and Food Chemistry, v.50, p.1260-1263, Feb. 2002.

LAGOS, M.B.; FERNANDES, M.I.; CAMARGO O.C.E.; FEDERIZZI, L.C.; CARVALHO, F.I.F. Genetics and monossomic analysis of aluminium tolerance in wheat (Triticum aestivum L.). Revista Brasileira de Genética, v.14, n.4, p.1011-1020, Dec. 1991.

LANTERI, S.; PICKERSGILL, B. Chromosomal structural changes in Capsicum annuum L. and C. chinense Jacq. Euphytica, v.67, n.1-2, p.155-160, 1993.

LEETE, E.; LOUDEN, M.C.L. Biothynthesis of capsaicin and dihydrocapsaicin in Capsicum frutescens. Journal of the American Chemical Society, v.90, n.24, p.6837-6841, Nov. 1968. 
LINDSEY, K.; BOSLAND, P.W. A field study of environmental interaction on pungency. Capsicum and Eggplant Newsletter, v.14, p.36-38, 1995.

MATHER, S.K.; JINKS, J.L. Biometrical genetics. 3.ed. Great Britain: Butler \& Tanner, 1971. 382p.

NUEZ, F.; ORTEGA, R.G.; COSTA, J. El cultivo de pimientos, chiles y ajies. Madrid: Ediciones Mundi-Prensa, 1995. 607p.

PADILHA-CONTRERAS, M.; YAHIA, E.M. Changes in capsaicinoids during development, maturation, and senescence of chille peppers and relation with peroxidase activity. Journal of Agricultural and Food Chemistry, v.46, n.6, p.2075-2079, 1998.

PARRISH, M. Liquid chromatographic method for determining capsaicinoids in capsicums and their extractives: collaborative study. Journal of AOAC International, v.79, n.3, p.738-745, 1996.

PULCINELLI, C.E. Herança do teor de proteína em soja. Piracicaba, 1992. 67p. Dissertação (M.S.) - Escola Superior de Agricultura "Luiz de Queiroz", Universidade de São Paulo.

RAMALHO, M.A.P.; SANTOS, J.B.; ZIMMERMANN, M.J.O. Genética quantitativa em plantas autógamas. Goiânia: Editora da UFG, 1993. 271p.

RAO, S.R.; RAVISHANKAR, G.A. Biotransformation of protocatechuic aldehyde and caffeic acid to vanillin and capsaicin in freely suspended and immobilized cell cultures of Capsicum frutescens. Journal of Biotechnology, v.76, p.137-146, 2000. 
REIFSCHNEIDER, FJB. (Ed.). Capsicum pimentas e pimentões no Brasil. Brasília: Embrapa Comunicação para Transferência de Tecnologia/Embrapa Hortaliças, 2000. $113 p$.

RIBEIRO, A.; COSTA, C.P da. Inheritance of pungency in Capsicum chinense Jacq. (Solanaceae). Revista Brasileira de Genética, v.13, n.4, p.815-823, Dec. 1990.

SACCARDO, F. Il miglioramento del peperone (objetive, tecniche, programmi). In: Colana I'Italia agricola. Miglioramento genetico dei vegetali. Roma: Ramo editoriale digli agricoltori, 1992. p.182-194.

SÀNCHEZ-CHACÒN, C.D. Herança da tolerância e sensibilidade à tolerância do alumínio em aveia (Avena sativa L.). Porto Alegre, 1998. 73p. Tese (Doutorado) - Universidade Federal do Rio Grande do Sul.

SMITH, P.G.; HEISER, C.B. Jr. Breeding behavior of cultivated peppers. American Society for Horticultural Science, v.70, p.286-290, 1957.

SOUZA, J.A.; MALUF, W.R. Estimação de heterose em pimenta (Capsicum chinense Jacq.). Ciência Agrotécnica, v.24, n.3, p.623-631, jul./set. 2000.

SOUZA Jr., C.L. Componentes da variância genética e suas implicações no melhoramento vegetal. Piracicaba: Fealq, 1989. 134p.

STEEL, R.G.D.; TORRIE, J.H. Principles and procedures of statistics. New York: McGraw-Hill, 1960. 481p.

TANKSLEY, S.D. Linkage relationships and chromosomal locations of enzyme-coding genes in pepper, Capsicum annuum. Chromosoma, v.89, n.5, p.352-360, May 1984. 
TANKSLEY, S.D.; IGLESIAS-OLIVAS, J. Inheritance and transfer of multiple flower character from Capsicum chinense into Capsicum annuum. Euphytica, v.33, n.3, p.769-777, Nov. 1984.

TAVARES, M.; MELO, A.M.T.; SCIVITTARO, W.B. Efeitos diretos e indiretos e correlações canônicas para caracteres relacionados com a produção de pimentão. Bragantia, v.58, n.1, p.41-47, 1999.

VENCOVSKY, R.; BARRIGA, P. Genética biométrica no fitomelhoramento. Ribeirão Preto: Revista Brasileira de Genética, 1992. 496p.

WAGNER, C.M.; LOPES, D.; RIBEIRO, C.S.C.; REIFSCHNEIDER, F.J.B.; VENCOVSKY, R. Influência da posição do fruto em plantas de pimenta no teor de capsaicinóides. / Apresentado ao 1 Simpósio Brasileiro de Especiarias, Ilhéus, 2000/.

WOODBURY, J.E. Determination of Capsicum pungency by high pressure liquid chromatography and spectrofluorometric detection. Journal of Association Official Analls of Chemistry, v.63, p.556-558, 1980.

YAGISHITA, N.; HIRATA, Y.; MIZUKAMI, H.; OHASHI, H.; YAMASHITA, K. Genetic nature of low capsaicin content in the variant strains induced by grafting in Capsicum annuum L. Euphytica, v.46, n.3, p.249-252, Apr. 1990.

ZEWDIE, Y.; BOSLAND, P.W. Capsaicinoid inheritance in an interspecific hybridization of Capsicum annuum $\mathrm{x} C$. chinense. Journal of American Horticultural Science, v.125, n.4, p.448-453, 2000a.

ZEWDIE, Y.; BOSLAND, P.W. Evaluation of genotype, environment, and genotype by environment interaction for capsaicinoids in Capsicum annuиm L. Euphytica, v.111, p.185-190, 2000 b. 